\author{
UNIVERSIDADE DE SÃO PAULO \\ ESCOLA DE ENFERMAGEM DE RIBEIRÃO PRETO
}

JOSELY PINTO DE MOURA

A adesão dos profissionais de enfermagem às precauções de isolamento na assistência aos portadores de microrganismos multirresistentes 
JOSELY PINTO DE MOURA

\title{
A adesão dos profissionais de enfermagem às precauções de isolamento na assistência aos portadores de microrganismos multirresistentes
}

\author{
Dissertação apresentada à Escola de \\ Enfermagem de Ribeirão Preto da Universidade \\ de São Paulo, para obtenção do Título de Mestre \\ em Enfermagem, junto ao Programa de Pós- \\ Graduação do Departamento de Enfermagem \\ Geral e Especializada inserida na linha de \\ pesquisa: Doenças Infecciosas: problemática, \\ especificidade e estratégias de enfrentamento.
}

Orientadora: Prof ${ }^{a}$ Dr $^{a}$ Elucir Gir

Ribeirão Preto

2004 


\section{FOLHA DE APROVAÇÃO}

\section{Josely Pinto de Moura}

A adesão dos profissionais de enfermagem às precauções de isolamento na assistência aos portadores de microrganismos multirresistentes

Dissertação apresentada à Escola de Enfermagem de Ribeirão Preto da Universidade de São Paulo, para obtenção do Título de Mestre em Enfermagem, junto ao Programa de PósGraduação do Departamento de Enfermagem Geral e Especializada inserida na linha de pesquisa: Doenças Infecciosas: problemática, especificidade e estratégias de enfrentamento.

\section{Aprovado em:}

\section{Banca Examinadora}

Prof. Dr.

Julgamento:

Assinatura:

Prof. Dr.

Julgamento:

Assinatura:

Prof. Dr. 
Ficha catalográfica preparada pela Seção de Tratamento Da Informação do Serviço de Biblioteca - EERP-USP

Moura, Josely Pinto

A adesão dos profissionais de enfermagem às precauções de isolamento na assistência aos portadores de microrganismos multirresistentes / Josely Pinto de Moura - Ribeirão Preto, 2004.

Dissertação (Mestrado) -- Escola de Enfermagem de Ribeirão Preto - Universidade de São Paulo, 2004.

Orientadora: Prof ${ }^{a}$. Dra. Elucir Gir

1. Infecção Hospitalar. 2. Multirresistente.

3. Precauções. 
Minha mãe, obrigada por me ajudar nos momentos difíceis

Meu pai, pelo apoio e incentivo Henrique e Humberto, por me dar coragem para lutar e, por trazerem sentido e realização a minha vida 
À Deus e Nossa Mãe, que estiveram comigo em todos os momentos e por protegerem os nossos passos e nos abençoar

À Prof ${ }^{a}$ Dra. Elucir Gir, minha orientadora, por sua inteligência, receptividade e suas diretrizes seguras na condução deste trabalho À você dedico minha admiração e meu afeto

À diretoria da SCMP por acreditar neste projeto e ajudar a transformar este sonho em realidade

À Enfermeira Cecília Anita Guimarães Marques por sua colaboração e estímulo

Às enfermeiras Márcia de Souza Moragas e Helenice Vilela Esteves Silva por abrir as portas de sua unidade para possibilitar a realização deste estudo

À Prof ${ }^{a}$ Dra. Miyeko Hayashida, pela elaboração do banco de dados e pelas sugestões

À Dra. Rosana Porto Viana, Enf ${ }^{\text {as }}$ Sílvia Canini e Terezinha de Jesus Oliveira Rezuto por terem atuado como juízas do instrumento de pesquisa

Às participantes da banca de exame de qualificação, Dra. Renata Takahashi e Dra. Miyeko Hayashida pelas contribuições apresentadas

Aos funcionários da EERP-USP, biblioteca, sala de estudos, enfim todos os que, com presteza e gentileza nos ajudaram a conduzir nosso estudo

Ao secretário Reinaldo Antonio dos Santos pela sua colaboração

À EERP-USP, pelo acolhimento e incentivo ao nosso aperfeiçoamento

À todas as pessoas que me apoiaram, dando sua contribuição e incentivo em alguma das diversas etapas da pesquisa

Agradeço aos profissionais de enfermagem da Santa Casa de Passos entrevistados, por quem tenho um grande carinho por terem participado e colaborado com a realização

deste trabalho 


\section{RESUMO}

MOURA, J. P. A adesão dos profissionais de enfermagem às precauções de isolamento na assistência aos portadores de microrganismos multirresistentes. 2004. Dissertação Mestrado - Escola de Enfermagem de Ribeirão Preto, Universidade de São Paulo, Ribeirão Preto.

Com o evento da resistência dos microrganismos aos antimicrobianos, surgiram as cepas multirresistentes de difícil tratamento, e com isso tornou-se imprescindível a adesão total dos profissionais de saúde às precauções empregadas na assistência aos portadores desses microrganismos, visando evitar a sua disseminação no ambiente hospitalar. Este estudo do tipo descritivo transversal foi realizado em uma instituição de saúde filantrópica do interior de Minas Gerais, teve como objetivos avaliar a adesão dos enfermeiros, técnicos e auxiliares de enfermagem às medidas preventivas empregadas na assistência aos portadores desses microrganismos multirresistentes. A coleta de dados ocorreu no período de outubro a novembro de 2003 e os dados foram analisados qualitativa e quantitativamente. Utilizou-se do Método de análise de conteúdo de BARDIN (1977) e para a análise quantitativa de alguns dados, empregou-se a estatística descritiva, sendo os mesmos interpretados com base no significado atribuído por ROSENSTOCK (1974a). O Modelo de Crenças em Saúde (MCS) possibilitou identificar as barreiras físicas, cognitivas e psicológicas que justificaram a nãoadesão de alguns profissionais às medidas preventivas direcionadas ao portador de Bactérias Multirresistentes (BMR). Como resultado destas avaliações, identificou-se que as percepções dos profissionais de enfermagem relacionadas à severidade das doenças causadas por BMR eram adequadas, que a maioria dos profissionais entrevistados associou a gravidade das doenças causadas por BMR a tratamento difícil ou a maior índice de mortalidade, e outros associaram-nas a tratamento inexistente. Quanto à susceptibilidade da doença, o conhecimento dos profissionais a respeito da temática apresentou-se bastante limitado. Os 
profissionais se aperceberam como susceptíveis de contrair BMR, entretanto, somente alguns conseguiram identificar os grupos mais susceptíveis à infecção causada por BMR. Observouse uma influência favorável da instituição ao se constatar que proporciona aos profissionais as condições necessárias para que estes empreguem o Protocolo de Isolamento Específico. O comportamento dos profissionais em relação ao uso dos Equipamentos de Proteção Individual (EPI) evidenciou controvérsias, pois muitos relataram utilizar freqüentemente os paramentos, contudo admitiram que alguns profissionais não os utilizam rigorosamente por diversos motivos, sendo mais freqüentes: a crença de que não vão contrair a doença, diagnóstico tardio, ou por resistência, ou seja, injustificadamente “ ... não usa porque não quer ...”. Observou-se que muitos profissionais não aderem totalmente às precauções por opção pessoal, eles não têm o hábito de lavar as mãos ou friccioná-las com álcool na freqüência que deveriam, apesar de terem os materiais disponíveis. Acreditam que os benefícios à adesão são: proteção, prevenção de adquirir infecção/doenças, o fato de evitar a disseminação e sua segurança. Quanto às barreiras, mencionaram principalmente a falta de vagas, o diagnóstico tardio e a falta de alguns materiais. O estímulo para a ação, referido preferencialmente pelos profissionais, foi a abordagem informal na prática diária. Identificaram-se, ainda, a necessidade de elaborar estratégias de intervenção capazes de aprimorar a conduta dos profissionais de enfermagem e o levantamento dos problemas considerados imprescindíveis para percepção das crenças dos profissionais, a fim de se implementar efetivamente as estratégias que devem alterar positivamente a situação observada.

Palavras-chave: Infecção hospitalar, multirresistente, precauções. 


\begin{abstract}
MOURA, J. P. Adhesion of nursing professionals to isolation precautions in care for patients with multiresistant microorganisms. 2004. Master's Dissertation - Ribeirão Preto College of Nursing, University of São Paulo, Ribeirão Preto.
\end{abstract}

As microorganisms acquired resistance against antimicrobial agents, multiresistant strains appeared which are difficult to treat. Hence, the total adhesion of health professionals to the precaution measures used in care for patients with multiresistant microorganisms has become essential, with a view to avoiding their dissemination in the hospital environment. This descriptive transverse study was carried out at a philanthropic health institution in the interior of Minas Gerais, Brazil and aimed to evaluate the adhesion of nurses, nursing technicians and auxiliaries to prevention measures used in care for patients with these multiresistant microorganisms. Data were collected in October and November 2003 and were subject to qualitative and quantitative analysis. BARDIN's (1977) content analysis method was used. Descriptive statistics was used with a view to the quantitative analysis of some data, which were interpreted on the basis of the meaning attributed by ROSENSTOCK (1974a). The Health Belief Model (HBM) allowed us to identify the physical, cognitive and psychological obstacles that justify some professionals' non-adhesion to the prevention measures oriented towards patients with Multiresistant Bacteria (MRB). As a result of these evaluations, it was identified that nursing professionals adequately perceived the seriousness of diseases caused by MRB, that most of the interviewees linked up the gravity of diseases caused by MRB with difficult treatment or higher mortality rates, while others associated it with the inexistence of treatment. With respect to disease susceptibility, professionals demonstrated a rather limited knowledge about the theme. They perceived themselves as susceptible to MRB, although only some professionals managed to identify the groups that are most susceptible to infection by MRB. A favorable institutional influence was observed when 
verifying that the institution provides its professionals with the necessary conditions to use the Specific Isolation Protocol. Professional behavior in relation to Individual Protection Equipment (IPE) usage revealed controversies, since many of them mentioned frequent usage, although they admitted that some professionals do not use this equipment in a strict way, for different reasons, among which the most frequent were: the belief that they will not contract the disease, late diagnosis, or due to resistance, that is, without any justification “ ... they do not use it because they do not want to ...”. It was observed that many professionals choose not to adhere totally to the precaution measures. They are not used to washing their hands or scrubbing them with alcohol as frequently as they should, although the material is available. They believe that benefits of adhesion are: protection, prevention of infection/diseases, avoiding dissemination and their safety. With respect to obstacles, they mainly mentioned the lack of beds, late diagnosis and the lack of some kinds of material. As a stimulus towards action, professionals prefer the informal approach in daily practice. We also identified the need to elaborate intervention strategies capable of improving nursing professionals' behavior and surveyed the problems considered essential to perceive professional beliefs, with a view to the efficient implementation of strategies that should positively change this situation.

Keywords: Hospital infection, multiresistant, precautions. 


\section{RESUMEN}

MOURA, J. P. La adhesión de los profesionales de enfermería a las precauciones de aislamiento en la asistencia a los portadores de microorganismos multirresistentes. 2004. Disertación Maestría - Escuela de Enfermería de Ribeirão Preto, Universidad de São Paulo, Ribeirão Preto.

En conjunción con el evento de la resistencia de los microorganismos a los antimicrobianos, aparecieron las cepas multiresistentes de difícil tratamiento, y con eso se volvió imprescindible la adhesión total de los profesionales de salud a las precauciones empleadas en la atención a los portadores de esos microorganismos, con la finalidad de evitar su diseminación en el ambiente hospitalario. Este estudio descriptivo de tipo transversal fue realizado en una institución de salud filantrópica del interior de Minas Gerais, con objeto de evaluar la adhesión de los enfermeros, técnicos y auxiliares de enfermería a las medidas preventivas utilizadas en la atención a los portadores de esos microorganismos multiresistentes. La recolección de datos ocurrió en el período de octubre a noviembre de 2003 y los datos fueron analizados de manera cualitativa y cuantitativa. Utilizamos el Método de análisis de contenido de BARDIN (1977). La estadística descriptiva fue utilizada para el análisis cuantitativo de algunos datos, que fueron interpretados con base en el significado atribuido por ROSENSTOCK (1974a). El Modelo de Creencias en Salud (MCS) nos posibilitó identificar las barreras físicas, cognitivas y psicológicas que justificaron la no adhesión de algunos profesionales a las medidas preventivas dirigidas al portador de Bacterias Multiresistentes (BMR). Como resultado de estas evaluaciones, identificamos que las percepciones de los profesionales de enfermería con respecto a la severidad de las enfermedades causadas por BMR eran adecuadas, que la mayoría de los profesionales entrevistados asoció la gravedad de las enfermedades causadas por BMR a tratamiento difícil o a mayor índice de mortalidad, y otros las asociaron a tratamiento inexistente. Con respecto a la susceptibilidad a la enfermedad, el conocimiento de los profesionales a cerca del tema se 
mostró bastante limitado. Los profesionales se percibieron como susceptibles de contraer BMR. Sin embargo, sólo algunos lograron identificar los grupos más susceptibles a la infección causada por BMR. Fue observada una influencia favorable de la institución al constatarse que ofrezca a los profesionales las condiciones necesarias para el uso del Protocolo de Aislamiento Específico. El comportamiento de los profesionales con respecto al uso de los Equipos de Protección Individual (EPI) demostró controversias, ya que muchos relataron el uso frecuente de los paramentos. Sin embargo, admitieron que algunos profesionales no los utilizan rigurosamente por diversos motivos, entre los cuales son más frecuentes: la creencia de que no contraerán la enfermedad, diagnóstico tardío, o por resistencia, esto es, injustificadamente “ ... no utiliza porque no quiere ...”. Observamos que, para muchos profesionales, no adherir totalmente a las precauciones es una opción personal. No tienen el hábito de lavarse las manos o friccionárselas con alcohol tan frecuentemente como deban, a pesar de que tienen los materiales disponibles. Creen que los beneficios de la adhesión sean: protección, prevención de adquirir infección/enfermedad, el facto de evitar la diseminación y su seguridad. Con respecto a las barreras, mencionaron principalmente la falta de plazas, el diagnóstico tardío y la falta de algunos materiales. El estímulo preferido para la acción referido por los profesionales fue la aproximación informal en la práctica diaria. Todavía fue identificada la necesidad de elaborar estrategias de intervención capaces de mejorar la conducta de los profesionales de enfermería y fueron planteados los problemas considerados imprescindibles para percepción de las creencias de los profesionales, con objeto de implementarse efectivamente las estrategias que deben alterar positivamente la situación observada.

Términos-clave: Infección hospitalaria, multiresistente, precauciones. 


\section{LISTA DE QUADROS}

p.

Quadro 1 - Padrão de resistência aos antimicrobianos que deve ser informado ao SCIH...

Quadro 2 - Marcadores de Resistência de Bactérias Multirresistentes

Quadro 3 - Síndromes Clínicas que necessitam de Precauções Empíricas Adicionais ...

Quadro 4 - Doenças Infecciosas e Precauções Recomendadas.

43

Quadro 5 - Medidas de Prevenção e Controle de acordo com o tipo de procedimento .. 44 


\section{LISTA DE TABELAS}

Tabela 1 - Distribuição dos profissionais de enfermagem (N=42) da Clínica Médica do Hospital Geral de Passos - MG, segundo categoria profissional, sexo, idade, tempo de serviço, turno e unidade de trabalho, 2003.

Tabela 2 - Distribuição das respostas atribuídas pelos profissionais de enfermagem, relacionadas ao motivo da resistência bacteriana na Unidade de Clínica Médica do Hospital Geral de Passos - MG -MG, 2003.

Tabela 3 - Distribuição das respostas atribuídas pelos profissionais de enfermagem, relacionadas à localização das bactérias multirresistentes no organismo do paciente na Unidade de Clínica Médica do Hospital Geral de Passos - MG, 2003

Tabela 4 - Distribuição das respostas atribuídas pelos profissionais de enfermagem, relacionadas aos microrganismos citados como comumente encontrados na Unidade de Clínica Médica do Hospital Geral de Passos - MG, 2003.

Tabela 5 - Distribuição das respostas atribuídas pelos profissionais de enfermagem, relacionadas a pacientes mais susceptíveis a colonização por BMR na unidade de Clínica Médica do Hospital Geral de Passos - MG, 2003.

Tabela 6 - Distribuição das respostas atribuídas pelos profissionais de enfermagem, relacionadas aos tipos de transmissão das BMR na unidade de Clínica Médica d Hospital Geral de Passos - MG, 2003

Tabela 7 - Distribuição das respostas atribuídas pelos profissionais de enfermagem, relacionadas aos principais reservatórios das BMR na Unidade de Clínica Médica do Hospital Geral de Passos - MG, 2003.

Tabela 8 - Distribuição das respostas atribuídas pelos profissionais de enfermagem, relacionadas ao medo de contraírem BMR na unidade de Clínica Médica do Hospital Geral de Passos - MG, 2003

Tabela 9 - Distribuição das respostas atribuídas pelos profissionais de enfermagem, relacionadas como medidas essenciais para prevenção da infecção por BMR na Unidade de Clínica Médica do Hospital Geral de Passos - MG, 2003. 
Tabela 10 - Distribuição das respostas atribuídas pelos profissionais de enfermagem, relacionadas às atitudes do paciente ao ser informado sobre a necessidade do isolamento na Unidade de Clínica Médica do Hospital Geral de Passos - MG, 2003

Tabela 11 - Distribuição das respostas atribuídas pelos profissionais de enfermagem, relacionadas como medidas preventivas que devem ser empregadas para diminuir a disseminação das BMR na unidade de Clínica Médica do Hospital Geral de Passos - MG, 2003.

Tabela 12 - Distribuição das respostas atribuídas pelos profissionais de enfermagem, relacionadas à forma, local e ao profissional que orientou sobre as BMR na unidade de Clínica Médica do Hospital Geral de Passos - MG, 2003

Tabela 13 - Distribuição das respostas atribuídas pelos profissionais de enfermagem, relacionadas à opinião sobre a placa de isolamento colocada na porta do quarto do paciente na unidade de Clínica Médica do Hospital Geral de Passos - MG, 2003

Tabela 14 - Distribuição das respostas atribuídas pelos profissionais de enfermagem, relacionadas à lavagem das mãos ao cuidar de um portador de BMR na unidade de Clínica Médica do Hospital Geral de Passos - MG, 2003... 109

Tabela 15 - Distribuição das respostas atribuídas pelos profissionais de enfermagem, relacionadas à utilização do álcool glicerinado a 70\% nas mãos, na unidade de Clínica Médica do Hospital Geral de Passos - MG, 2003.

Tabela 16 - Distribuição das respostas atribuídas pelos profissionais de enfermagem, relacionadas aos benefícios que as medidas preventivas promovem aos mesmos na unidade de Clínica Médica do Hospital Geral de Passos - MG, 2003

Tabela 17 - Distribuição das respostas atribuídas pelos profissionais de enfermagem, relacionadas aos benefícios que adequação às medidas preventivas promovem aos “clientes” na unidade de Clínica Médica do Hospital Geral de Passos - MG, 2003.

Tabela 19 - Distribuição das respostas atribuídas pelos profissionais de enfermagem, relacionadas aos principais fatores que dificultam/impedem o emprego das medidas preventivas ao portador de na unidade de Clínica Médica do Hospital Geral de Passos - MG, 2003. 


\section{LISTA DE FIGURAS}

Figura 1- Modelo de Crenças em Saúde como preditor do comportamento

Figura 2 - “ Modelo de Crenças em Saúde”, como determinante do comportamento preventivo em saúde (ROSENSTOCK, 1974) 


\section{LISTA DE ABREVIATURAS E SIGLAS}

AC-MR - Acinetobacter Multirresistente

BMR - Bactérias Multirresistentes

CCIH - Comissão de Controle de Infecção Hospitalar

CDC - Centers for Disease Control

CEMA - Cepas de enterobactérias multirresistentes a antimicrobianos

CIPA - Comissão Interna de Prevenção de Acidentes

DHQP - Division of Healthcare Quality Promotion

DT - Doenças transmissíveis

EPI -Equipamentos de Proteção Individual

GISA - Staphylococcus aureus resistente a glicopeptídeos

HIV - Virus da Imunodeficiência Humana

KB-MR - Klebsiella Multirresistente

MARSA - Staphylococcus aureus Metilcilina Aminoglicosídeo Resistente

MAR-SCN - Staphylococcus coagulase negativa Metilcilina Aminoglicosídeo

Resistente

MARSE - Staphylococcus epidermidis Metilcilina Resistente

MBC - Concentração bacteriostática mínima

MCS - Modelo de Crenças em Saúde

MDR - Microrganismo multi-droga-resistente

MDR-TB - Micobactéria tuberculose multi-droga resistente

MIC - Concentração inibitória mínima

MRSA - Staphylococcus aureus metilcilina resistente 
NNISS - National Nosocomial Infection Surveillance System

OMS - Organização Mundial de Saúde

PA-MR - Pseudomonas aeruginosa Multirresistente

PP - Precauções Padrão

PSP-MR -Pseudomonas sp Multirresistente

PU - Precauções Universais

SCIH - Serviço de Controle de Infecção Hospitalar

SCMP - Santa Casa de Misericórdia de Passos

SIPAT - Semana Interna de Prevenção de Acidentes

TBMR - Tuberculose multirresistente

UTI - Unidade de Tratamento Intensivo

VISA - Staphylococcus aureus intermediário a vancomicina

VISTO - Staphylococus aureus intermediário a vancomicina e ao teicoplamin

VRE - Enterococus vancomicina-resistente 


\section{SUMÁRIO}

p.

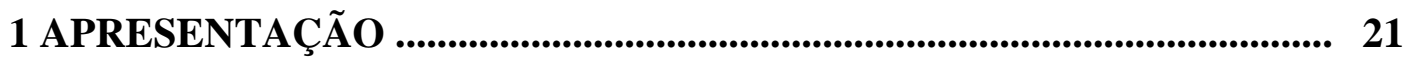

2 INTRODUÇÃO .................................................................................................. 23

3 PRESSUPOSTOS ....................................................................................... 31

4 REVISÃO DE LITERATURA …..................................................................... 36

5 REFERENCIAL TEÓRICO........................................................................ 47

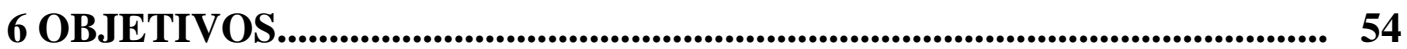

7 METODOLOGIA _.................................................................................... 55

8 APRESENTANDO E DISCUTINDO OS RESULTADOS ............................ 66

8.1 Caracterização dos profissionais de enfermagem.............................................. 68

8.2 Conhecimento dos profissionais de enfermagem acerca das Bactérias

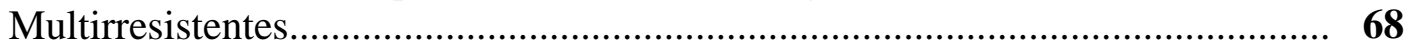

8.2.1 Causas da multirresistência bacteriana ........................................................... 68

8.2.2 Riscos para a equipe de saúde ................................................................ 72

8.2.3 Localização das BMR no organismo humano............................................... 74

8.2.4 Microrganismos mais comumente encontrados no ambiente hospitalar...... 77

8.2.5 Pacientes mais susceptíveis à colonização por BMR ................................... 78

8.2.6 Modo de transmissão das bactérias multirresistentes.................................... 83

8.2.7 Principais reservatórios das bactérias multirresistentes ............................... 85

8.2.8 Profissionais que orientam sobre as precauções a serem observadas no cuidado aos portadores de BMR............................................................... 86

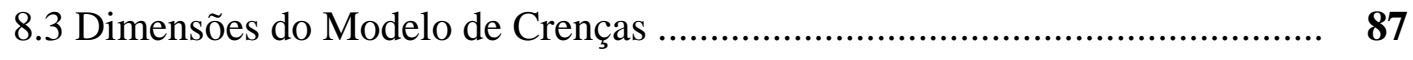

8.3.1 Percepção de susceptibilidade da doença pelo funcionário............................ 87

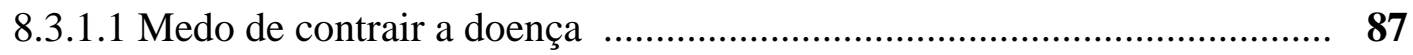

8.3.1.2 Medidas de prevenção da doença .............................................................. 91 
8.3.1.3 Atitudes do paciente frente à doença e a necessidade de isolamento

8.3.2 Percepção da Severidade da doença pelos profissionais de enfermagem ...

8.3.3 Influência da instituição.

8.3.4 Influência Pessoal.

8.3.5 Relação entre benefícios e barreiras

8.4 Modelo de Crenças em Saúde como determinante do comportamento preventivo em saúde

8.4.1 Percepções Individuais

8.4.1.1 Percepção de susceptibilidade da doença.

8.4.1.2 Percepção da severidade da doença.....

8.4.2 Fatores Modificadores

8.4.2.1 Estímulos para ação

8.4.2.1.1 Influência da instituição

8.4.2.2 Variável psicossocial (personalidade)

8.4.2.2.1 Influência Pessoal

8.4.3 Probabilidade de Ação

8.4.3.1 Relação entre benefícios e barreiras

8.4.3.2 Probabilidade de praticar a ação preventiva recomendada.

9 CONSIDERAÇÕES FINAIS 


\section{APRESENTAÇÃO}

A necessidade de prevenção visando à transmissão de patógenos é fato bem estabelecido tanto na literatura, quanto na prática profissional. Acredita-se que a adesão dos profissionais às medidas de isolamento não é totalmente adotada, pois com o evento da resistência dos microrganismos aos antimicrobianos, surgiram as cepas multirresistentes de difícil tratamento, exigindo adesão total às precauções na assistência aos portadores, visando evitar a sua disseminação.

Como enfermeira da Comissão de Controle das Infecções Hospitalares (CCIH) de um Hospital Geral de Passos - Minas Gerais, há seis anos, sempre nos preocupamos com esse fato, tanto que realizamos treinamentos diversos para atualização do pessoal de enfermagem, com o objetivo de estimular a adesão destes profissionais ao Protocolo de Isolamento Específico adotado pela instituição. Contudo, em nossa observação diária e através de manifestações verbais espontâneas de funcionários tanto em discussões em grupo como em palestras, constatamos a presença de falhas na adoção do referido "Protocolo Específico de Isolamento”. Assim, visando sanar essas falhas, bem como supervisionar a sistemática dessa atividade, decidimos realizar este estudo para avaliar à adesão às medidas preventivas empregadas pelos enfermeiros, técnicos e auxiliares de enfermagem na assistência portadores de microrganismos multirresistentes no Hospital Geral de Passos - MG.

Acreditamos que este estudo poderá contribuir com a melhoria do emprego do Protocolo Específico de Isolamento, bem como com a evidência das falhas e, portanto poderá proporcionar meios de solucioná-las na instituição em estudo, além de servir, ainda, de alerta e referencial a outras instituições. Na literatura ainda não encontramos estudos direcionados especificamente a microrganismos multirresistentes, porém levando em consideração as pesquisas de adesão à lavagem das mãos, que são inúmeras, e as referentes ao Isolamento de 
maneira geral, observamos que os resultados são preocupantes e nos induzem a buscar os motivos que levam a inúmeras falhas na adoção das medidas preventivas para isolamento específico. Estamos vivendo um momento único, no qual a disseminação dos microrganismos multirresistentes poderá nos levar à era pós-antibiótica, ou seja, nos encontraremos diante da situação que não permitirão qualquer opção de tratamento para os portadores destas cepas, problema de difícil solução para o portador e para as instituições, que deverão arcar com os altos custos destes tratamentos.

Estudos que demonstram a eficiência de medidas de precauções direcionadas ao isolamento para abortarem surtos eminentes confirmaram a importância destes procedimentos para evitar a disseminação destes microrganismos. Nesse contexto, entendemos que é nossa responsabilidade adotar tais procedimentos, supervisioná-los, como também aperfeiçoá-los.

Inquieta este pesquisador o aumento gradual dos microrganismos multirresistentes, a conduta tomada pelas diversas instituições na adoção de modelos específicos de isolamento, assim como a adesão de seus profissionais às medidas de prevenção. É também preocupante a vigilância epidemiológica dos portadores de microrganismos multirresistentes e a escassez de estudos sobre o assunto. Assim, acreditamos que o presente estudo poderá ampliar a visão dos profissionais frente ao problema, despertando-os para a responsabilidade de evitarem a disseminação dessas cepas multirresistentes dentro das instituições, e que associem sua responsabilidade às condutas médicas de uso racional de antimicrobianos. 


\section{INTRODUÇÃO}

A era do uso clínico dos antibióticos tem pouco mais de meio século; vai desde a introdução do mais antigo antibiótico (penicilina G) até o mais recente. É inegável a sua importância e as suas indicações clínicas, entretanto vêm-se acumulando uma frustrante e deletéria experiência de desenvolvimento crescente da resistência bacteriana aos antibióticos. A resistência bacteriana ocorre devido à dependência da pressão seletiva imposta a estas populações bacterianas. Embora possa ser considerada como uma conseqüência natural do uso dos antibióticos, na realidade, a resistência tem sido bem mais exteriorizada em função do intenso e extenso uso dos antibióticos, muitas vezes inadequado e abusivo. Atualmente não são tão excepcionais os pacientes acometidos por infecções para as quais existam poucas, ou, por vezes, nenhuma alternativa terapêutica (RODRIGUES et al., 1997).

As infecções que se desenvolvem nos pacientes hospitalizados podem ser causadas por bactérias trazidas da comunidade para dentro do hospital ou pelos próprios pacientes; por bactérias que já estavam presentes no hospital, sejam nos pacientes (causando infecção ou como colonizantes), ou na equipe assistencial (como colonizantes) ou no ambiente inanimado.

Para obterem sucesso como patógenos hospitalares, as bactérias devem ser capazes de se estabelecer e sobreviver no ambiente hospitalar; de colonizar a mucosa e a pele de pacientes e membros da equipe assistencial e de resistir à ação dos antibióticos, sejam eles incidentais ou direcionados especificamente contra elas. Então, além das resistências naturais, próprias de tais bactérias, uma importante condição de sobrevivência destas, passa a ser a capacidade de aquisição adicional de novos determinantes de resistência, evidentemente correlacionável com a freqüente exposição aos antibióticos (RODRIGUES et al., 1997). 
Não há dúvida de que as bactérias que causam as infecções hospitalares, ou que colonizam os pacientes e os profissionais que lá trabalham, são mais resistentes aos antibióticos do que as oriundas da comunidade, pois a resistência a antibióticos é característica mais ligada ao hospital do que à comunidade, muito embora não seja exclusiva do primeiro.

Em algumas circunstâncias, a expressão da resistência aos antibióticos está acompanhada de alteração da virulência do patógeno, podendo, por vezes, a expressão de certos fenótipos de resistências estar associada a uma virulência aumentada, com sugestão epidemiológica de morbidade e mortalidade aumentada, comparativamente à observada para as cepas sensíveis, mesmo após correção para o possível “confouding effect” das doenças subjacentes (CHOW et al., 1991).

São indicativos de sucesso os exemplos nos quais a limitação do uso do antibiótico, entendido como responsável, ou as medidas de controle de infecção (tais como: as precauções de barreira para pacientes infectados e colonizados) revelaram-se capazes de abortar surtos sérios de bactérias multirresistentes.

Então, o uso criterioso dos antibióticos e o emprego cuidadoso das medidas de controle são, provavelmente, as melhores armas para combater, de forma previsível, a emergência e a disseminação de bactérias multirresistentes.

Nossa capacidade de tratar pacientes acometidos por infecções bacterianas nunca esteve tão ameaçada com tal magnitude, em decorrência, da alteração/transformação de cepas de bactérias em multiplamente resistentes, capazes de escassear ou diminuir as opções clínicas úteis para o tratamento, ou mesmo impossibilitar o tratamento na ausência de novas classes de antibióticos ativos contra estas bactérias multirresistentes.

Para lidar com esta ameaça, os clínicos e os profissionais de controle de infecção devem abordar o problema simultaneamente em várias direções, pois segundo Rodrigues et al. 
(1997), devem controlar a disseminação das cepas multirresistentes com o uso racional dos antibióticos e emprego metódico de medidas de controle. Para os autores, os profissionais precisam conhecer melhor os mecanismos de disseminação da resistência, estabelecer métodos mais precisos para a detecção fenotípica precoce da resistência e aumentar os conhecimentos sobre os mecanismos dessa resistência, com a finalidade de obterem no futuro antibióticos “ecologicamente mais corretos”.

Os Centers for Disease Control and Prevention (CDC,1997) lançaram as Precauções Padrão, em 1996, e a partir do momento que os profissionais de saúde tomaram conhecimento dessas medidas e aceitaram suas recomendações, reduziram a ocorrência dos acidentes ocupacionais.

Estudo de McCOY et al., (2001), referente aos fatores associados à maior adequação destes profissionais às normas preventivas, demonstrou a inadequação dessas normas, no isolamento investigado.

Os autores encontraram baixa aderência às precauções padrão em diversas situações, Por exemplo: 55\% dos enfermeiros e $81 \%$ dos médicos não empregavam barreiras no momento da exposição muco-cutânea, tendo estes últimos referido que, freqüentemente, deixavam de utilizar luvas (22\%), máscaras (19\%) ou óculos (13\%), alegando para esta verdadeira “desobediência-padrão” interferência no trabalho; não haver disponibilidade dos Equipamentos de proteção individual (EPI) no local do atendimento; inconveniência do seu uso; inabilidade para seu emprego e desconhecimento do seu papel preventivo.

Os resultados desse estudo demonstraram que o ambiente de trabalho e o apoio gerencial têm um papel considerável na adequação entre treinamento e aderência às recomendações, destacando a importância dos supervisores na orientação e no reforço das práticas adequadas. Ainda mostraram que a disseminação de informação sobre os riscos dos patógenos transmitidos pelo sangue é de grande valor, assim como devem-se disponibilizar os 
EPI nos locais necessários, realizar treinamento especial direcionado principalmente aos profissionais de apoio. Os autores do estudo comprovaram menor incidência de acidentes onde os treinamentos foram mais amplos e efetivos.

Portanto, ao analisarmos a resistência antimicrobiana no ambiente hospitalar, bem como seu impacto, tendências e intervenções bem sucedidas para prevenção e controle de surtos, encontramos um alarmante aumento da resistência tanto das bactérias Gram-negativas quanto das Gram-positivas. Como sabemos, as Unidades de Terapia Intensiva (UTI) são o epicentro destes surtos, mas ocorre que os microrganismos multirresistentes disseminam-se destas unidades para todo o hospital, transcendendo o ambiente hospitalar, chegando aos domicílios e a outros locais cuja referência são os pacientes atendidos. Tal situação é alimentada, sobretudo, pela pressão seletiva decorrente do uso indiscriminado dos antimicrobianos (JARWIS, 2000 ).

Por que devemos nos preocupar com a resistência microbiana? São inúmeras as razões, dentre as quais estão: os custos imediatos devidos às novas exigências para o tratamento do paciente, que incluem: emprego de antibióticos de custo mais elevado, prolongamento da internação, sem contar os riscos que se submetem os profissionais de saúde. Como custos potenciais contabilizamos a produtividade perdida com os pacientes infectados e a possibilidade real de infecções intratáveis. Em um passado remoto, a indústria farmacêutica procurou sanar este problema desenvolvendo antimicrobianos melhores que os anteriores, porém, hoje, isso já não acontece, em conseqüência de não se priorizar investimentos nesta área e incrementar outras áreas emergentes.

Se observarmos os dados do National Nosocomial Infection Surveillance System (NNISS) sobre as taxas de resistência dos patógenos nosocomiais em Unidades de Cuidados Intensivos e compararmos os referentes ao período de 1993 a 1997 com os do período de janeiro a novembro de 1998, veremos que o número de infecções causadas pelo Enterococo 
resistente à vancomicina aumentou significativamente; do mesmo modo, o Staphylococcus aureus meticilina resistente aumentou em mais de 50\% as infecções em pacientes das UTI, enquanto a resistência da E. coli e da Klebsiella sp às cefalosporinas de terceira geração não mostrou alteração significativa. Quanto à resistência do Pseudomonas aeruginosa e do Acinetobacter ao imipenem, ela está começando a aumentar, e o mesmo vem ocorrendo com a Pseudomonas aeruginosa versus as quinolonas, confirmando assim, aumento da resistência microbiana nos hospitais (JARWIS, 2000).

O Diretor Geral da Organização Mundial de Saúde refere que estamos perdendo a batalha para os microrganismos, isto porque não se produzem mais novos antibióticos na mesma velocidade de resistência dos microrganismos. Um contundente documento sobre o tema, repleto de exemplos, confirma, entre outras coisas, que "a emergência da resistência microbiana é o sinal mais evidente que nós não temos levado a sério a ameaça das doenças infecciosas”. O relatório de doenças infecciosas, elaborado em 1999, “Removing Obstacles to Healthy Development,” demonstrou que as doenças transmissíveis permanecem como uma causa significante de morte, principalmente entre as populações carentes, no entanto o relatório de 2000 que enfoca a resistência às drogas e como este problema está minando a possibilidade do tratamento de muitas doenças infecciosas, informa que se continuar assim, a resistência microbiana para o tratamento poderá devolver o mundo à era pré-antibiótica (OMS,2000).

Nenhuma população é mais vulnerável aos microrganismos multirresistentes do que os pacientes hospitalizados. Dos microrganismos multirresistentes que proliferam agora em todo o mundo, nenhuma leva maior potencial para destruição e ameaça às intervenções médicas, que o aparecimento de superinfecções adquiridas no hospital. Apenas nos Estados Unidos, aproximadamente 14.000 indivíduos são infectados e morrem a cada ano, em conseqüência dos micróbios multirresistentes adquiridos nos hospitais. Salmonella, Pseudomonas e Klebsiella estão entre as bactérias que manifestam níveis altos de resistência, notavelmente nas nações em desenvolvimento. Outras infecções, por exemplo as causadas por Staphylococcus aureus metilcilina-resistente (MRSA) e Enterococcus vancomicina resistente (VRE), também estão preocupando os profissionais que atuam em hospitais. Durante os anos cinqüenta a maioria das infecções 
estafilocócicas era susceptível à penicilina. Agora, no começo do novo milênio, quase todas são resistentes não só a penicilina, mas também crescentemente impenetráveis às novas drogas que sucessivamente foram desenvolvidas para quebrar a barreira da resistência. (OMS, 2000, p. 18).

Até pouco tempo, a única droga disponível para tratamento das infecções era a vancomicina, porém o Staphylococcus aureus com resistência intermediária a esta droga, conhecido como VISA, já está emergindo, mostrando níveis de resistência por enquanto ainda manejáveis, mas ameaça evoluir e colocar esta droga na lista da resistência.

Os procedimentos para prevenção e controle de infecções estafilocóccicas associadas à redução da sensibilidade à vancomicina, onde estão descritos Staphylococus aureus metilcilina-resistente (MRSA), o Staphylococcus com resistência intermediária à vancomicina (VISA) ou glicopeptídeo (GISA), o Staphylococcus com resistência intermediária à vancomicina e a teicoplamina e outras drogas atualmente em experimentações clínicas nos Estados Unidos também conhecido como VISTO e o Staphylococcus aureus resistente à vancomicina (VRSA) podem variar de um hospital para o outro, mas a recomendação descrita na seqüência é utilizada na maioria das instituições de saúde, de acordo com os CDC (CDC, 2002a; CDC, 2002c).

O paciente é colocado em um quarto privativo com um ou mais pacientes, que também tem MRSA, sendo sua movimentação limitada somente às finalidades essenciais, ou seja, para procedimentos ou emergências médicas. Quanto ao uso de luvas e avental, utilizá-los antes de entrar no quarto do paciente e removê-los ao sair e lavar as mãos ao sair do quarto. As orientações aos visitantes incluem paramentos com luvas e avental, se estiverem ajudando a cuidar do paciente e lavagem das mãos sempre antes de saírem do quarto do paciente. Estas medidas acentuam-se quando trata-se de Staphylococcus aureus intermediário ou resistente à vancomicina (CDC, 2002a).

O MRSA é transmitido basicamente de um indivíduo para o outro e pelos profissionais, cujas mãos ficam transitoriamente contaminadas pela assistência ao paciente 
colonizado/infectado por MRSA. No caso de profissionais com dermatite, ou lesões de pele, colonizadas com MRSA, há maior probabilidade de transmissão deste microrganismo, no entanto a transmissão pela vias aéreas ocorre apenas se o paciente apresentar pneumonia, traqueobronquite, colonização de trato respiratório por MRSA ou infecções de pele extensas secretantes (pacientes queimados).

Em relação aos principais reservatórios de microrganismos multirresistentes, destacamos o paciente colonizado/infectado; o profissional de saúde com colonização persistente e as superfícies ambientais contaminadas, principalmente na transmissão de MRSA em unidades de queimados. Sendo assim, o procedimento de descolonização é requerido a todo paciente infectado, independente do tratamento sistêmico instituído.

A presença do MRSA no ambiente hospitalar implica em:

- $\quad$ Limitação de tratamento imposta pela multirresistência aos antimicrobianos, já que apenas dois antibióticos podem ser utilizados com segurança no seu tratamento: a vancomicina e a teicoplamina. Embora algumas cepas sejam sensíveis à ciprofloxacina, pode ocorrer emergência de resistência durante o tratamento.

- $\quad$ Rapidez de propagação da bactéria, isto é, uma vez endêmico, torna-se extremamente difícil o controle da disseminação.

As medidas de prevenção e controle dependem das particularidades de cada hospital e da situação a ser abordada, quais sejam: surto ou endemia, incidência observada, distribuição dos pacientes acometidos, dentre outras.

No Hospital Geral de Passos - MG, as medidas adotadas visam reduzir a velocidade da disseminação dos microrganismos multirresistentes, cumprindo seu papel junto à comunidade e clientela, contudo estas ações são exercidas por profissionais com características, conhecimentos e formação distintos. Nesse sentido, decidimos realizar este estudo para avaliarmos se as orientações estão sendo seguidas por todos os profissionais de saúde de 
maneira adequada, pois somente a barreira física não é suficiente para conter a disseminação dos microrganismos. Também procuramos identificar e conhecer os fatores dificultadores para implantação do Protocolo de Isolamento, visando à eliminação dos mesmos, para medirmos a sintonia existente entre as ações dos profissionais e, conseqüentemente, o sucesso desta missão. Este levantamento também servirá de alerta a outras instituições para possíveis “desobediências” de seus profissionais às medidas preventivas.

O conhecimento prévio e o treinamento dos profissionais de saúde para medidas preventivas de isolamento são atributos necessários para as instituições, devido à possibilidade de ocorrência de surtos. 


\section{PRESSUPOSTOS}

Uma das preocupações do epidemiologista hospitalar é a prevenção da disseminação de cepas bacterianas patogênicas entre os pacientes hospitalizados, missão que se torna bastante difícil quando estes patógenos expressam resistências problemáticas aos antibióticos. Atualmente, nossa capacidade para barrar a disseminação dos determinantes de resistência entre as bactérias, no ambiente natural, é precária, pois os fatores que afetam a transferência não são bem conhecidos. Contudo, documento divulgado pela Organização Mundial de Saúde (OMS) relaciona estes fatores e define os pontos de ação, visando antepor esta resistência (OMS, 2000).

Parece válida a idéia de que a pressão ambiental é dependente do uso excessivo dos antibióticos, por isso desempenha significativo papel na disseminação destes determinantes de resistência.

Quanto aos fatores que favorecem a resistência microbiana, documento da OMS (2000) relaciona os seguintes fatores: o paradigma da pobreza e o acesso inadequado aos medicamentos; erro diagnóstico; medicamentos falsificados; a preferência por medicamentos caros de largo espectro; publicidade pressionando os pacientes a utilizarem as novas drogas; deficiência na formação de profissionais de saúde; alimentos originários de animais com bactéria resistente, e que posteriormente atinge nossa espécie; a globalização, que propiciou as viagens internacionais e o intercâmbio comercial e, finalmente, a resistência própria de hospitais que, adicionalmente, contam com a desatenção a técnicas apropriadas de controle de infecção.

Sendo antes consideradas mera curiosidade médica, tais infecções multirresistentes explodiram em uma das principais crises do sistema de saúde. 
Numa chamada para desenvolver esforços capazes de promoverem tratamento efetivo, a OMS (2000) definiu os seguintes pontos para ação:

1. Adotar políticas e estratégias definidas e estabelecidas para a maioria das doenças que visam especificamente à sua prevenção, tratamento e controle, destacando-se a imunização com uma das suas mais importantes políticas. Às doenças para as quais não existe vacina, disponibilizar outras ferramentas efetivas. A vigilância da resistência microbiana é uma outra parte crítica nesta luta, pois identifica tendências a infecções específicas e localizações geográficas.

2. Educar os profissionais de saúde e o público no uso de medicamentos, principalmente no uso adequado de antimicrobianos, é imperativo, assim como deter a expansão da resistência.

3. Conter a resistência no hospital: as pessoas ingerem a maioria dos antimicrobianos nas suas casas, porém é no hospital que seu uso é mais intenso, principalmente em unidades repletas de pacientes, onde é mais fácil a disseminação de patógenos multirresistentes como o MRSA. É imperativo que os hospitais mobilizem as habilidades profissionais dos administradores, clínicos, farmacêuticos, microbiologistas e outros profissionais da saúde a buscarem soluções criativas na tentativa de resolverem o problema da resistência microbiana. Desenvolver políticas e práticas que assegurem o uso criterioso dos antimicrobianos é um passo vital e o primeiro a ser tomado, do mesmo modo que a vigilância ao aumento de resistência é igualmente imperativa. A OMS também encoraja os hospitais a monitorarem o uso dessas drogas, juntamente com o controle de infecção, a fim de prevenirem a transmissão e a expansão dos organismos multirresistentes. Para tanto, aconselha:

4. Diminuir o uso de antimicrobianos na pecuária.

5. Desenvolvimento de pesquisas para criação de novas drogas e vacinas.

6. Construir alianças e parcerias para aumentar o acesso aos antimicrobianos. 
7. Aumentar a disponibilidade dos medicamentos essenciais.

8. Fabricação de medicamentos efetivos, e que estes estejam disponíveis aos mais pobres.

É muito real o risco potencial da resistência microbiana nos levar de volta a um mundo de morte prematura e enfermidades crônicas. Nossos avós viveram em um mundo sem antibióticos. Isso poderá acontecer com nossos netos. Nós temos os meios para assegurar que os antibióticos permaneçam efetivos, mas estamos correndo contra o tempo. A nossa porta para continuar ajudando os infelizes portadores das doenças infecciosas pode estar se fechando (OMS, 2000, p. 27).

Portanto, o papel dos hospitais deve ser o de manter políticas de uso racional de antimicrobianos, assim como prevenir a transmissão e a expansão dos microrganismos multirresistentes.

De acordo com Sievert et al. (2002), o S. aureus é um dos principais agentes da infecção hospitalar e vem apresentando resistência aos antibióticos empregados no seu tratamento. Na trajetória dessa resistência, surgiram nos anos 50 as cepas resistentes à penicilina; os anos 80 viram crescer a resistência à oxacilina; na década de 90, observou-se a resistência intermediária à vancomicina e, em 2000, a transferência da resistência do enterococcus sp à vancomicina para o S.aureus. Felizmente esta cepa foi suscetível a outros antibióticos e as medidas incluídas nas precauções-padrão e associadas ao isolamento de contato (luvas, máscara e lavagem das mãos com sabonete anti-séptico) foram suficientes para impedir sua transmissão (SIEVERT et al, 2002). Este fato vem confirmar a necessidade de implementarmos medidas de prevenção da transmissão destes microrganismos.

A importância de prevenção da transmissão é um fato, contudo, a inexistência de estudos que registrem a adesão total dos profissionais de saúde aos Protocolos de Precaução e Isolamento adotados pelas instituições visando à disseminação de microrganismos multirresistentes também é preocupante. Citaremos, a seguir, alguns estudos nos quais são observados apenas o uso de EPI, enquanto outros reforçam a adesão à lavagem das mãos, todos porém praticam uma adesão parcial e quase sempre insatisfatória. 
Um destes estudos pesquisou os componentes utilizados pela equipe de enfermagem de um hospital público especializado em doença infecto-contagiosa do município de São Paulo, com o objetivo de avaliar a aceitação e a aplicação das precauções universais quanto à transmissão. Compuseram a amostra; 39 enfermeiros, 99 auxiliares de enfermagem e 67 atendentes de enfermagem. Os resultados demonstraram que a população-alvo aceitava as recomendações das Precauções Universais (PUs), porém apresentava falhas de conhecimento relativas à sua definição, utilizava as PUs mas desconhecia a implementação de barreiras recomendadas em diversos procedimentos e que o uso incorreto das recomendações deveu-se, também à falta do equipamento ou ainda à não-disponibilidade deste na unidade de internação, à economia de tempo na paramentação, à dificuldade de acesso à literatura atualizada e ao desconhecimento do diagnóstico médico, em alguns casos (JEUKENS, 1997).

O estudo "Aspectos da assistência a pacientes internados em unidade de isolamento de um Hospital Escola sobre medidas preventivas utilizadas e custo do paciente-dia”, no atendimento de pacientes com diagnóstico de meningite bacteriana, demonstrou que a utilização de parâmetros não foi condizente com as orientações dos manuais de isolamento, pois o ato de lavar as mãos na maioria das vezes não foi realizado, independentemente da categoria e da situação do paciente, entre outros aspectos (NAKAO, 1988).

Fato semelhante pode estar ocorrendo com os sistemas de isolamento para microrganismos multirresistentes uma vez que eles também associam as precauções-padrão a medidas específicas, o que torna ainda mais complexo o aprendizado da equipe de enfermagem.

Há vários anos dispomos de informações epidemiológicas que demonstram a eficácia da aplicação das medidas preventivas para evitar a ocorrência de casos secundários. Entretanto, com freqüência, observamos médicos e paramédicos com pouco conhecimento dos riscos e das medidas de prevenção, subestimando os riscos de infecção para si e para os pacientes que cuida diretamente. Existe a necessidade de reverter esta situação e conscientizar os profissionais de saúde sobre a real importância das precauções e isolamento. A literatura médica registra surtos de infecção hospitalar que poderiam ser prevenidos se as técnicas de precauções e isolamento fossem aplicadas apropriadamente (APECIH, 1999 p.2). 
Como não existem na literatura estudos específicos sobre a questão, os profissionais de saúde devem investigar se a política de isolamento adotada pelas instituições para controle de microrganismos multirresistentes está sendo adequadamente instituída, e no caso de falhas, identificá-las e orientar como saná-las, pois somente dessa maneira estaremos instituindo programas eficazes de prevenção à disseminação de microrganismos multirresistentes. E a pesquisa, neste caso, é o instrumento mais indicado para obtermos este conhecimento, o qual repercutirá na melhoria da assistência dos serviços prestados. 


\section{REVISÃO DE LITERATURA}

Em busca sistemática realizada em banco de dados Medline, Lilacs, Scielo, Dedalus, observamos a escassez da temática referente a adesão às medidas preventivas empregadas aos pacientes com multirresistência bacteriana. Foram encontrados diversos artigos relacionados com a multirresistência, porém quando cruzamos esse descritor com precauções, não encontramos nenhum artigo.

\subsection{Resistência a antimicrobianos}

Os investigadores descobriram que os microrganismos desenvolvem resistência a antimicrobianos por meio de um processo conhecido como seleção natural, assim, quando uma população microbiana é exposta a um antibiótico, os microrganismos mais suscetíveis são destruídos, sobrevivendo somente os resistentes ao antimicrobiano. Estes organismos podem passar os genes de resistência à sua descendência através de replicação ou ainda, para outras bactérias relacionadas, através da conjugação, por meio de plasmídios, que levam os genes de um organismo para outro. Este processo natural é exacerbado pelo abuso de antimicrobianos no tratamento das enfermidades humanas, sendo utilizado também na pecuária, piscicultura e agricultura. A doença e a resistência a ela associada também prosperam em condições de instabilidade civil, de pobreza, migração de massa e degradação ambiental, principalmente quando há exposição de grande número de pessoas às doenças infecciosas, aliada à ineficiência dos serviços de saúde (OMS, 2000).

Um dos principais objetivos dos programas de controle de infecções hospitalares é o de prevenir a disseminação de patógenos multirresistentes. 
O reconhecimento de padrões de resistência emergentes é feito inicialmente pelo laboratório de microbiologia clínica, através dos testes de sensibilidade que identificam estes agentes (ainda que presuntivamente) de modo mais correto e o mais rápido possível, informando imediatamente ao Serviço de Controle de Infecção Hospitalar (SCIH).

Grande parte dos laboratórios informa os seguintes padrões de resistência:

Quadro 1 - Padrão de resistência aos antimicrobianos que deve ser informado ao Serviço de Controle de Infecção Hospitalar.

\begin{tabular}{|c|c|}
\hline Resistência & Agentes \\
\hline $\begin{array}{l}\text { Quinolona } \\
\text { Meticilina (Oxacilina) }\end{array}$ & $\begin{array}{l}\text { Staphylococcus coagulase-negativo } \\
\text { Staphylococcus aureus }\end{array}$ \\
\hline $\begin{array}{l}\text { Beta-lactâmicos } \\
\text { Aminoglicosídeos } \\
\text { glicopeptítdeos }\end{array}$ & Enterococci \\
\hline Penicilina & Streptococcus pneumoniae \\
\hline Vancomicina & $\begin{array}{l}\text { Cocos gram-positivos: } \\
\text { S. haemolyticus } \\
\text { Enterococcus spp } \\
\text { Lactobacillus spp } \\
\text { Pediococcus spp } \\
\text { Leuconostoc spp } \\
\text { S. aureus com sensibilidade } \\
\text { mediária á vancomicina (VISA) }\end{array}$ \\
\hline Beta-lactâmicos de espectro ampliado & $\begin{array}{l}\text { Enterobacteriaceae, particularmente: } \\
\text { E. coli } \\
\text { Klebsiella spp } \\
\text { Citrobacter }\end{array}$ \\
\hline Polienos imidazolicos & $\begin{array}{l}\text { Aspergillus spp } \\
\text { Cândida krusei } \\
\text { C. lusitaniae } \\
\text { C. ( Torulopsis ) glabrata }\end{array}$ \\
\hline
\end{tabular}

Fonte: STARLING, C. E. F.; SILVA, E. U. (Coord.). Controle de Infecções Hospitalares:

microbiologia aplicada ao controle de infecções hospitalares. Belo Horizonte: IEA, 1998b. Cap. 10, p. 14. apud PFALLER, M. A.; CORMICAN, M. G. in: WENZEL, R. P.

Contudo, não existe uma definição-padrão para resistência múltipla de bactérias, usualmente consideramos como sendo multirresistentes os microrganismos com resistência a duas ou mais classes de antimicrobianos aos quais as bactérias são normalmente susceptíveis 
(STARLING; SILVA , 1998a). O Hospital Geral de Passos - MG, utiliza a tabela a seguir para identificar as cepas multirresistentes e solicitar o Isolamento Específico, sendo a mesma elaborada por consenso, com um padrão freqüentemente utilizado nas instituições.

\section{Quadro 2 - Marcadores de Resistência de Bactérias Multirresistentes}

\begin{tabular}{|c|c|c|}
\hline Bactéria & Sensível & Resistente \\
\hline $\begin{array}{l}\text { S. aureus } \\
\text { S. epidermidis } \\
\text { S. coagulase negativa }\end{array}$ & - & Oxacilina \\
\hline Enterococcus & Só sensível à Vancomicina & Vancomicina \\
\hline Streptococcus pneumoniae & - & Oxacilina \\
\hline $\begin{array}{l}\text { Klebsiella } \\
\text { E. coli } \\
\text { Enterobacter } \\
\text { Citrobacter } \\
\end{array}$ & Sensível à Cefoxitina & $\begin{array}{l}\text { Cefoxitina ou Ceftazidina ou } \\
\text { Ceftriaxona ou Aztreonan }\end{array}$ \\
\hline Serratia & - & $\begin{array}{l}\text { Gentamicina } \\
\text { Amicacina } \\
\text { Ceftriaxona } \\
\text { Cefotaxima } \\
\text { Ciprofoloxacina }\end{array}$ \\
\hline $\begin{array}{l}\text { Burlkoderia cepacia } \\
\text { S. maltophilia }\end{array}$ & - & Todas \\
\hline Acinetobacter & $\begin{array}{c}\text { Imipenem e/ou } \\
\text { Ampicilina/Sulbactam }\end{array}$ & - \\
\hline Pseudomonas aeruginosa & $\begin{array}{c}\text { Imipenem ou Ceftazidima ou } \\
\text { Cefepime ou só sensível a } \\
\text { Polimixina } \\
\end{array}$ & - \\
\hline Staphylococcus viridans & - & Penicilina \\
\hline Morganella & - & Ciprofloxacin \\
\hline
\end{tabular}

Fonte: Serviço de Controle de Infecção Hospitalar do Hospital das Clínicas da Faculdade de Medicina de Ribeirão Preto - USP. 


\subsection{Sistema de Precauções e Isolamento}

O objetivo básico de um sistema de precauções e isolamento é a prevenção da transmissão de microrganismo de um paciente, portador são ou doente, para outro, de forma direta ou indireta. Esta prevenção abrange medidas aplicáveis tanto aos pacientes, como aos profissionais de saúde, que também podem servir como veículo de transmissão destes microrganismos. Um segundo objetivo é a prevenção de transmissão de microrganismos para o profissional de saúde.

Diversas normas de precauções e isolamento foram elaboradas com base nestes objetivos e a evolução e características destas normas refletem um melhor conhecimento mais profundo acerca dos modos de transmissão, da prevalência e da relevância de doenças transmissíveis num dado momento, bem como o desenvolvimento de técnicas de prevenção. A norma mais aplicada ou adaptada em hospitais é aquela elaborada pelos CDC e pelo HICPAC (Hospital Infection Control Practices Advisory Commitee), divulgada em 1996 (CDC, 1997). Este novo sistema de precauções e isolamento contempla somente dois níveis: as precauções-padrão que devem ser aplicadas a todos os pacientes independentemente de sua condição infecciosa (com ou sem a presença de doenças transmissíveis) e as precauções baseadas nos modos de transmissão, direcionadas a pacientes com suspeita ou diagnóstico confirmado de infecção, as quais são classificadas em Precauções de Contato e Precauções Respiratórias para gotículas e para aerossóis infectantes.

Denomina-se precauções padrão ao conjunto das medidas exigidas pela precaução universal e pela precaução com fluidos corporais. A precaução padrão deve ser aplicada a todo paciente, independente de seu estado infeccioso; esta, aliás, a razão da denominação padrão. Ela parte do princípio de que, não se tendo idéia da presença e da concentração de microrganismos nos diversos fluidos corporais do paciente, o profissional de saúde precisa considerar a todos como potencialmente infectados (STARLING ; SILVA, 1998a). 
Apresentamos, a seguir, alguns cuidados exigidos pelas precauções-padrão, juntamente com os especificamente requeridos para o isolamento:

- Os profissionais de saúde com lesões exsudativas ou dermatite devem ser avaliados quanto à possibilidade de serem mantidos em suas funções, desde que utilizem paramentação adequada (luvas, máscara, óculos protetores e capote). Caso isto não seja possível, ou quando estiverem desempenhando funções em áreas críticas (unidades de terapia intensiva, berçário de alto risco, unidades de queimados etc.), devem ser afastados da assistência direta ao paciente e do manuseio de instrumentais e equipamentos, até seu completo restabelecimento.

- $\quad$ As mãos precisam ser lavadas imediatamente após:

- a remoção das luvas;

- a contaminação com sangue ou outros fluidos (devendo-se proceder da mesma forma com outras superfícies corporais).

- Usar luvas - descartando-as logo após a assistência prestada a cada paciente, sempre que:

- houver risco de contato com sangue e outros fluidos corporais;

- houver contato com mucosas e pele não-intacta;

- realizar qualquer procedimento invasivo, como aspiração, entubação, punção, acesso vascular;

- lavar artigos e superfícies contaminados com sangue e outros fluidos corporais.

- Usar máscaras e óculos protetores toda vez que os procedimentos envolverem risco de projeção de gotículas potencialmente infectantes, para prevenir a exposição de mucosas da cavidade oral, nasal e ocular à sangue, secreções ou outros fluidos corporais.

- Usar capote sempre que houver risco de contaminação do vestuário com sangue e outros fluidos corporais. 
- Usar equipamentos de ventilação ao prestar assistência respiratória, em substituição à respiração boca-a-boca.

- $\quad$ Cuidados gerais:

- precaver-se de lesões com materiais perfuro-cortantes durante procedimentos, como: - manuseio, limpeza ou descarte;

- não quebrar, reencapar ou remover agulhas de seringas descartáveis; - descartar os materiais perfuro-cortantes em recipientes rígidos; - acondicionar as roupas de cama do vestuário do paciente e os materiais reutilizáveis que tenham entrado em contato com sangue e outros fluidos corporais.

- $\quad$ Proceder a lavagem correta das mãos, utilizar luvas, avental, máscara ou proteção facial para evitar o contato com materiais do paciente, como sangue, líquidos corporais, secreção ou excretas, pele não-intacta e mucosas. Portanto, deverão ser monitoradas a utilização dos EPI pelos auxiliares e técnicos de enfermagem”(STARLING; SILVA, 1998a).

Esse sistema de isolamento tem sido utilizado com freqüência em hospitais de São Paulo e do restante do Brasil, devido à facilidade de compreensão e a praticidade de aplicação (APECIH, 1999). Consiste na adaptação das recomendações dos CDC, que contêm dois tipos de precauções: a primeira e mais importante refere-se às precauções projetadas para o cuidado de todos os pacientes nos hospitais, não obstante seu diagnóstico ou status presumido de infecção. A execução destas “precauções-padrão” é a estratégia preliminar para um controle nosocomial bem sucedido da infecção. Em segundo lugar, estão as precauções projetadas para o cuidado de pacientes específicos, conhecidos ou suspeitos de infecção ou colonização com patógenos epidemiologicamente importantes, que podem ser transmitidos por via aérea ou gotícula ou, ainda, pelo contato com pele e superfícies contaminadas. Este último procedimento pode ser combinado para as doenças com mais de um tipo de transmissão e associados às precauções padrão. 
Contudo, o Hospital Geral de Passos - MG, utiliza o sistema de Isolamento Específico, mais conhecido como Procedimentos 1, 2, 3 e 4, cuja seqüência numérica refere-se à necessidade do uso de itens para o isolamento, ou seja o Procedimento 1 requer 1 item luvas; Procedimento 2 requer 2 itens - luvas e avental; Procedimento 3 requer 3 itens - luvas, avental e máscara e Procedimento 4 - apenas máscara, sistema bem aceito pelo pessoal por ser de fácil aplicação. Quanto ao isolamento específico, este é associado às precauções-padrão (PP) e ao Isolamento em Situações Especiais (STARLING ; SILVA, 1998a ). A orientação quanto ao tipo de máscara a ser utilizada, se para aerossóis ou gotículas, não está prevista neste modelo de isolamento, tais informações são repassadas em treinamentos e pelo enfermeiro da unidade. Este item necessita ser inserido neste modelo para facilitar e assegurar o tipo de paramentação adequado. Portanto, ele segue o mesmo princípio do "Guideline” do CDC e HICPAC - Precauções para Isolamentos em Hospitais, de 1996 (CDC, 1997).

\subsection{Protocolo de Isolamento Específico do Hospital Geral de Passos - MG}

O Hospital Geral de Passos - MG utiliza as recomendações estabelecidas no modelo de isolamento específico, as quais determinam o uso de paramentação adequado aos profissionais que prestam assistência ao paciente portador de microrganismo multirresistente, (STARLING; SILVA, 1998a). 
Quadro 3 - Síndromes Clínicas que necessitam de Precauções Empíricas Adicionais

\section{Síndrome ou Condição Clínica}

Risco de Microrganismo Multirresistente:

- história de infecção ou colonização por bactéria multirresistente COM infecção respiratória

- história de infecção ou colonização por bactéria multirresistente SEM infecção respiratória

- infecção de pele, ferida ou infecção do trato urinário em hospital com alta incidência de microrganismo multirresistente
Microrganismo

Multirresistente

Microrganismo

Multirresistente

Microrganismo 2 multirresistente
Proced.

Fonte: STARLING, C. E. F.; SILVA, E. U. (Coord.). Controle de Infecções Hospitalares: isolamento, precauções e controle de bactérias multirresistentes. Belo Horizonte: IEA, 1998a. Cap. 9, p. 24.

\section{Quadro 4 - Doenças Infecciosas e Precauções Recomendadas}

\begin{tabular}{|c|c|c|c|c|}
\hline \multicolumn{5}{|c|}{ Tipo de Precaução: } \\
\hline $\begin{array}{l}1=\text { Procedimento } 1 \\
2=\text { Procedimento } 2\end{array}$ & $\begin{array}{l}3=\text { Procedimento } 3 \\
4=\text { Procedimento } 4\end{array}$ & $\begin{array}{l}\text { PP }=\text { Precaução Padrão } \\
\text { QP = Quarto privativo }\end{array}$ & \multicolumn{2}{|l|}{$\mathrm{C}=$ Coorte } \\
\hline \multicolumn{5}{|c|}{ Duração da Precaução: } \\
\hline \multicolumn{5}{|c|}{$\begin{array}{l}\mathrm{CN}=\text { Manter o isolamento até o término do antibiótico efetivo e resultado de cultura } \\
\text { negativo. }\end{array}$} \\
\hline \multicolumn{5}{|c|}{$\begin{array}{l}\mathrm{CD}=\text { Manter o isolamento durante a duração da doença e, no caso de lesões secretantes, } \\
\text { até o término da trenagem }\end{array}$} \\
\hline \multicolumn{5}{|c|}{$\begin{array}{l}\mathrm{H}=\text { Após o início da terapêutica específica, manter o isolamento pelo período de tempo } \\
\text { especificado. }\end{array}$} \\
\hline \multirow{2}{*}{ Infecção } & & & Precauções & \multirow{2}{*}{$\begin{array}{l}\text { Ver Nota } \\
\text { ( no final ) }\end{array}$} \\
\hline & & Tipo & Duração & \\
\hline \multicolumn{5}{|c|}{$\begin{array}{l}\text { Multirresistentes, microrganismos (infecção ou } \\
\text { colonização): }\end{array}$} \\
\hline \multirow{2}{*}{$\begin{array}{ll}\text { - } & \text { gastrointestinal } \\
\text { - } & \text { respiratória } \\
\text { - } & \text { pneumocócica }\end{array}$} & \multirow{4}{*}{\multicolumn{2}{|c|}{$\begin{array}{c}2+\mathrm{QP} / \\
\mathrm{C} \\
3+\mathrm{QP} / \\
\mathrm{C} \\
\mathrm{PP} \\
2+\mathrm{QP} / \\
\mathrm{C}\end{array}$}} & $\mathrm{CN}$ & - \\
\hline & & & $\mathrm{CN}$ & - \\
\hline \multirow[t]{2}{*}{ - $\quad$ pele, ferida, quei } & & & - & - \\
\hline & & & $\mathrm{CN}$ & - \\
\hline
\end{tabular}

Fonte: STARLING, C. E. F.; SILVA, E. U. (Coord.). Controle de Infeç̧ões Hospitalares: isolamento, precauções e controle de bactérias multirresistentes. Belo Horizonte: IEA, 1998a. Cap. 9, p. 25. 
Quadro 5 - Medidas de Prevenção e Controle de acordo com o tipo de procedimento

\begin{tabular}{|c|c|}
\hline Tipo de Procedimento & Medidas de Prevenção e Controle \\
\hline Procedimento 1 & $\begin{array}{l}\text { - Lavar as mãos antes e após o contato } \\
\text { com o paciente. } \\
\text { - Usar luvas ao contato com o paciente, } \\
\text { excreções, secreções corporais e objetos } \\
\text { contaminados }\end{array}$ \\
\hline Procedimento 2 & $\begin{array}{l}\text { - Lavar as mãos antes e após o contato } \\
\text { com o paciente. } \\
\text { - Usar luvas e capote ao contato com o } \\
\text { paciente, excreções, secreções corporais } \\
\text { e objetos contaminados. }\end{array}$ \\
\hline Procedimento 3 & $\begin{array}{l}\text { - Lavar as mãos antes e após o contato } \\
\text { com o paciente. } \\
\text { - Usar luvas e capote ao contato com o } \\
\text { paciente, excreções, secreções corporais } \\
\text { e objetos contaminados. } \\
\text { - Usar máscara ao entrar na área de } \\
\text { isolamento. }\end{array}$ \\
\hline Procedimento 4 & $\begin{array}{l}\text { - Lavar as mãos antes e após o contato } \\
\text { com o paciente. } \\
\text { - Usar máscara ao entrar na área de } \\
\text { isolamento. }\end{array}$ \\
\hline
\end{tabular}

Fonte: STARLING, C. E. F.; SILVA, E. U. (Coord.). Controle de Infecções Hospitalares: isolamento, precauções e controle de bactérias multirresistentes. Belo Horizonte: IEA, 1998a. Cap. 9, p. 25.

Este modelo de Isolamento Específico compreende medidas para conduta com paciente com história de infecção ou colonização por bactérias multirresistentes, sendo que o tipo de procedimento adotado deverá ser associado às precauções-padrão, conforme normas dos CDC, que sugerem a adoção de medidas específicas em situações não contempladas no seu manual, devendo a situação ser avaliada pela CCIH (CDC, 1997). 
As medidas básicas adotadas pelo Hospital Geral de Passos - MG, conforme modelo apresentado e em sintonia com as orientações dos CDC, são as seguintes:

- colher material para culturas e instituir as precauções para conter a propagação da bactéria, assim que existir alguma suspeita;

-buscar a detecção precoce, através da revisão diária dos exames microbiológicos (culturas e antibiogramas);

-identificar os pacientes de risco, suspeitando sempre daqueles transferidos de instituições com alta incidência de MRSA, de unidades de terapia intensiva e de outras unidades de risco.

Na verdade, devemos tomar os devidos cuidados com todos os pacientes transferidos, tendo em vista a alta incidência desse microrganismo nas instituições hospitalares; identificar os casos sabidamente colonizados/infectados no momento da admissão. Os pacientes, alvo de suspeição, são todos aqueles com doenças crônicas, com múltiplas hospitalizações e que realizaram diálise ou procedimentos invasivos por tempo prolongado, já que tendem a permanecer colonizados por vários meses e não devem responder ao processo de descolonização.

O isolamento de paciente colonizado/infectado em quarto privativo é o procedimento mais indicado. No caso de dois ou mais pacientes com cultura positiva para MRSA utilizar o isolamento de coorte, ou seja, com mais de um paciente isolado no mesmo quarto com o mesmo microrganismo identificado, desde que não haja outra condição que impeça o agrupamento.

Nas situações em que os procedimentos adequados, forem adotados, o paciente poderá ser mantido junto a outros com baixo risco para aquisição de MRSA, porém longe daqueles que se submeteram a procedimentos invasivos, portadores de múltiplas deficiências 
funcionais, de úlceras de decúbito, dos que encontram-se em pós-operatório e dos imunossuprimidos.

Adicionalmente às precaução-padrão, devemos adotar o Procedimento 2, ou em caso de pneumonia, traqueobronquite ou lesões extensas de pele com secreção não contida, adotar

\section{o Procedimento 3.}

Quanto ao procedimento de descolonização, este deve ter como população-alvo os indivíduos sabida ou potencialmente colonizados/infectados por MRSA, quando o objetivo da descolonização for o de reduzir os reservatórios intra-hospitalares de MRSA.

Concluindo, diante do aumento global da resistência microbiana, as instituições de todo mundo que visam à redução do seu aparecimento e à prevenção da sua expansão demandam esforços no sentido de incluírem o uso criterioso dos antibióticos e a rígida aderência aos princípios do controle de infecção. Desse modo, procuraram reduzir, respectivamente, a pressão seletiva que favorece essas cepas microbianas e a sua transmissão, as quais colonizam e infectam os paciente internados.

O SCIH do Hospital Geral de Passos - MG realiza busca ativa e diária no Laboratório Clínico para identificar precocemente a presença de bactérias multirresistentes e assim instituir medidas preventivas preconizadas. Também os bioquímicos responsáveis pelo laboratório de microbiologia são participativos e atuam como colaboradores do SCIH, agindo de forma multidisciplinar, devendo comunicar ao SCIH e aos clínicos dos pacientes a ocorrência de casos novos.

Após a identificação do caso, a enfermeira, ou a médica do SCIH entra em contato com o médico do paciente para comunicar o fato, a fim de que este adote as medidas preventivas necessárias. Também comunica a ocorrência à enfermeira chefe da Unidade para que esta providencie o Isolamento, solicite o quarto privativo e separe os equipamentos, além de orientar os funcionários e os visitantes a respeito. 


\section{REFERENCIAL TEÓRICO}

\subsection{O Modelo de Crenças em Saúde}

Compreender as razões que levam os profissionais de saúde a aderirem às medidas preventivas que devem ser adotadas no cuidado ao portador de Bactérias Multirresistentes (BMR) significa compreender a influência de fatores ambientais e psicossociais no comportamento destes profissionais. Dentre os fatores psicossociais, as crenças e os valores parecem influenciar nas atitudes dos profissionais de enfermagem a aderirem ou não às medidas preventivas relacionadas ao cuidado do portador de BMR. Assim, resolvemos analisar essa situação, partindo das seguintes questões: Quais seriam as crenças dos profissionais de saúde relacionadas a essa prática? Eles acreditam e consideram-na eficiente? Existem barreiras para a adoção desta prática? Que tipo de treinamento deve ser fornecido pela instituição? Os profissionais são influenciados pelo comportamento de outros colegas? A instituição propicia as condições adequadas para o cumprimento deste Protocolo? Ela estimula com benefícios os profissionais a adotarem essa prática?

As respostas a essas questões a adoção de um modelo teórico que possibilitasse a explicação do comportamento preventivo em saúde, enfocando a adesão dos profissionais à prevenção da transmissão de patógenos aos portadores de BMR.

A opção recaiu sobre o Modelo de Crenças em Saúde (MCS), o Health Belief Model, por ser considerado,“[...] o principal modelo para explicar e predizer a aceitação de recomendações sobre cuidados com a saúde”segundo Janz e Becker (1984, p.1). Realizando uma revisão na qual utilizaram estudos com o MCS, na década de 1974 a 1984, avaliaram um total de 46 estudos, sendo 24 deles aplicados a comportamentos preventivos. Esta opção pelo MCS ocorreu porque ele atendia exatamente aos objetivos propostos pelos autores. Esse 
modelo foi desenvolvido por um grupo de psicólogos sociais do Serviço de Saúde Pública dos Estados Unidos, no início dos anos 50 (JANZ ; BECKER,1984).

Este modelo originalmente formulado por Hochbaum; Leventhal; Kegeles e Rosenstock e publicado por Rosenstock, em 1966, visava a explicação da ação preventiva sendo, posteriormente aplicado a comportamentos relacionados à manutenção da saúde em geral (COLETA, 2004). Rosenstock (1974b) fez uma revisão do MCS aplicado a comportamentos preventivos, citando definições de Kasl e Cobb (1966) a respeito dos diferentes comportamentos de saúde. Assim, Comportamento na saúde (health behavior) é “[...]qualquer atividade empreendida por uma pessoa que acredita estar saudável, como o propósito de prevenir doenças ou de detectá-las em um estágio assintomático”. O autor define como Comportamento frente ao sintoma (illness behavior): “[...]qualquer atividade empreendida por uma pessoa que se sente doente, com o propósito de definir seu estado de saúde e de descobrir o remédio adequado”; como comportamento na doença (sick-role behavior) refere “[...] a atividade empreendida por aqueles que se consideram doentes, com o propósito de curar-se” Conjuntamente, estas definições aparecem sob o nome genérico de Comportamento de saúde, significando que são executados com o fim de manterem ou recuperarem a saúde. Contudo, as diferentes percepções e cognições que acompanham cada uma das situações possuem distinções importantes. Portanto, o Comportamento na saúde aplica-se ao objetivo deste estudo.

De acordo com Rosenstock (1974a), o MCS é composto basicamente de quatro dimensões :

- $\quad$ Susceptibilidade percebida - refere-se à percepção subjetiva do risco pessoal de contrair uma doença;

- $\quad$ Severidade percebida - a gravidade ou seriedade da doença pode ser avaliada pelo grau de perturbação emocional criado ao pensar na doença quanto pelos tipos de conseqüências que a doença pode acarretar: dor, morte, gasto material, interrupção de atividades, perturbações nas relações familiares e sociais, etc.,...);

- $\quad$ Benefícios percebidos - referem-se à crença na efetividade da ação e à percepção de suas conseqüências positivas; 
- $\quad$ Barreiras percebidas - os aspectos negativos da ação são avaliados em uma análise do tipo custo-benefício, considerando possíveis custos de tempo, dinheiro, esforço, aborrecimentos, etc, ...

O potencial para a ação é resultado dos níveis combinados de susceptibilidade e de severidade percebidas na doença, enquanto a modalidade de ação é escolhida em função da percepção dos benefícios, menos as barreiras percebidas nas alternativas comportamentais. Outras variáveis podem afetar a percepção individual influenciando indiretamente a ação final . São os fatores biográficos, psicossociais e estruturais, elementos cuja interação com os demais está reproduzida graficamente na figura 1”.

Percepções Individuais

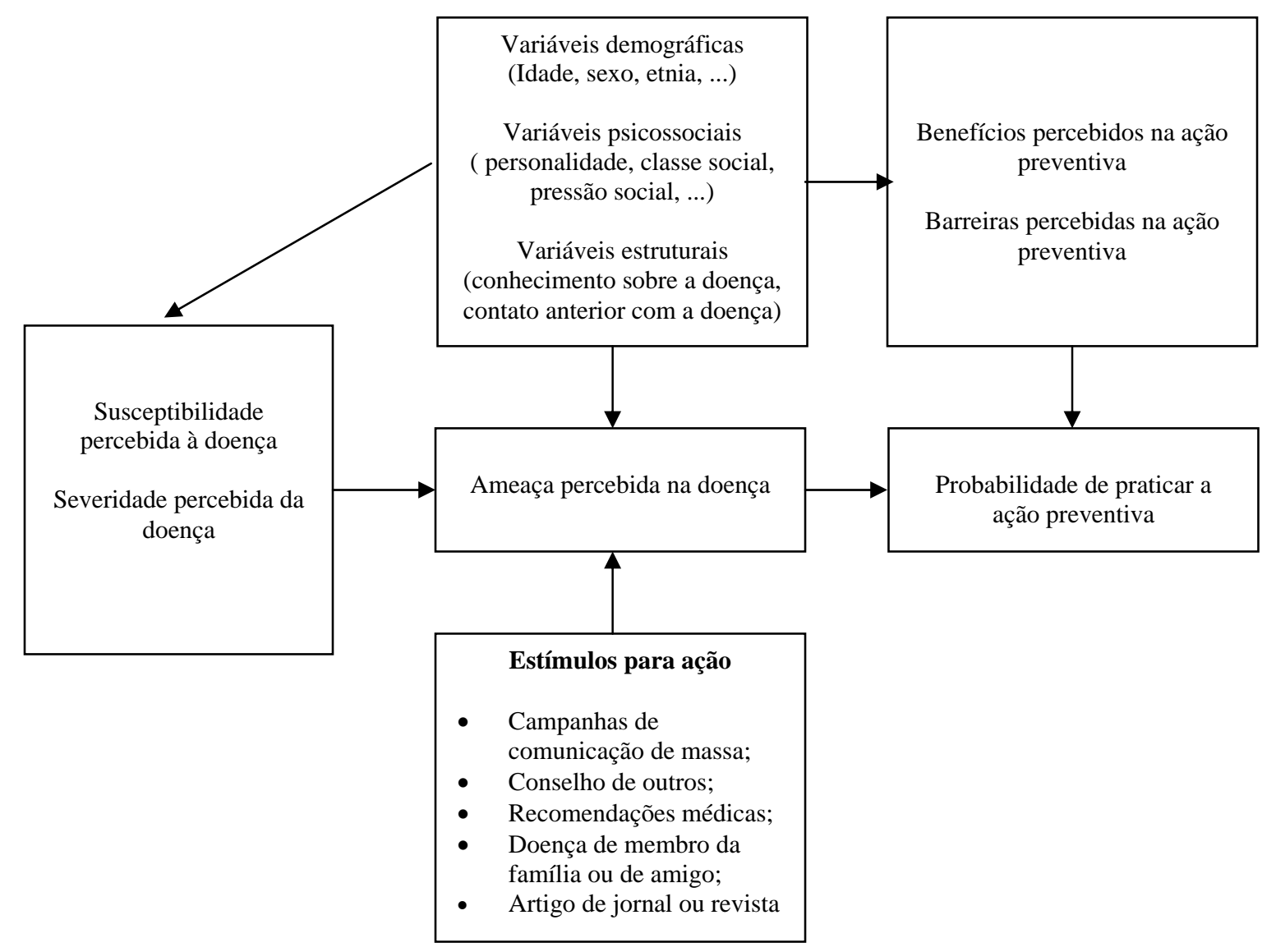

Fatores Modificadores

Probabilidade de Ação

FIGURA 1 - Modelo de Crenças em Saúde como preditor do comportamento preventivo (Rosenstock, 1974b) 
Rosenstock (1974b), como já referido, fez uma revisão dos estudos sobre MCS e prevenção, analisando criticamente esse modelo já que nos primeiros estudos não fizera formulação do conceito motivacional. Para o autor, a motivação é uma condição necessária para ação e o indivíduo seleciona a motivação segundo a determinação das percepções do ambiente. Em 1975, Becker et al. publicam estudo sobre a aplicação do MCS na detecção da doença de Tay-Sachs, doença genética grave que pode ser diagnosticada através do exame do líquido amniótico, com o bebê no útero. Esta foi, segundo Rosenstock (1974b), a primeira vez que a motivação para a saúde foi introduzida no modelo para explicação de um comportamento preventivo .

Este modelo vem sendo aperfeiçoado desde 1984 , e também vem ocorrendo uma crescente aplicação do mesmo em diversos estudos, de diferentes áreas, principalmente na enfermagem, psicologia e medicina, relacionadas a moléstias e condutas relacionadas á saúde (COLETA,2004). 


\begin{tabular}{|l|l|l|}
\hline PERCEPÇÕES INDIVIDUAIS & FATORES MODIFICADORES & PROBABILIDADE DE AÇÃO \\
\hline
\end{tabular}

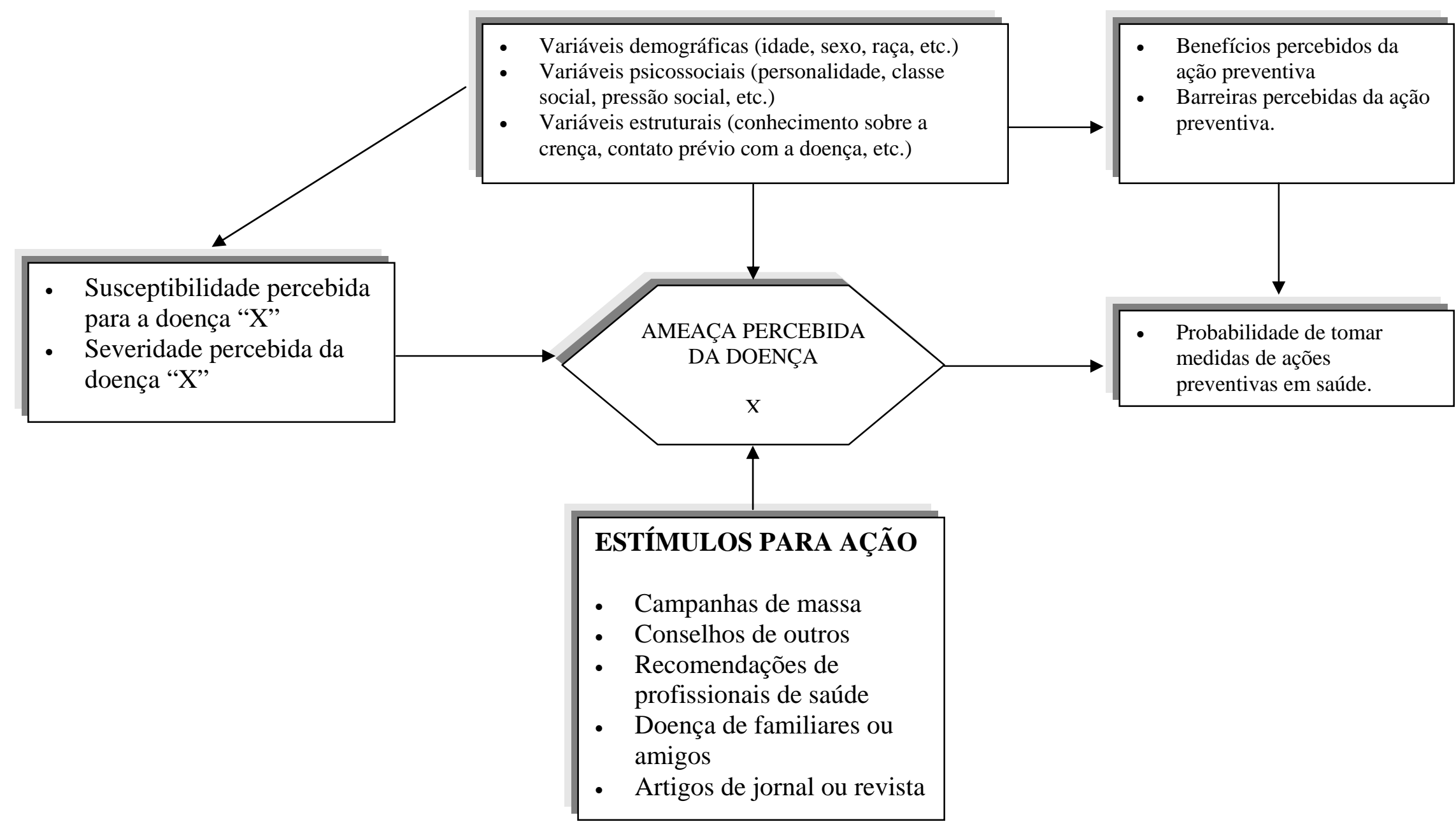

Figura 2 - “ Modelo de Crenças em Saúde”, como determinante do comportamento preventivo em saúde (ROSENSTOCK, 1974) 
Uma revisão feita por Janz e Becker (1984), sobre transmissão de infecção no ambiente hospitalar, na qual avaliaram 29 estudos desenvolvidos entre 1974 e 1984, revelou que os melhores resultados são obtidos com a variável "barreiras”, seguindo a de “benefícios”, “susceptibilidade” e "severidade”, nesta ordem. No estudo citado, a susceptibilidade foi preditora somente em uma análise referente ao modo de como entender o comportamento preventivo. A “severidade” não foi preditora significativa em nenhum dos comportamentos, no que diz respeito às análises relativas a sujeitos saudáveis, sugerindo ser mais importante frente ao sintoma ou diagnóstico da doença. A percepção sobre “benefícios” demonstrou, de maneira insuficiente, ser esta uma condição necessária para a adesão, visto que os estudos apontaram concordância dos sujeitos sobre os benefícios da adesão, embora ela nem sempre ocorra, e a razão citada quase sempre foi uma "barreira" aos comportamentos (COLETA, 1995).

Os motivos da adesão dos profissionais de saúde às medidas preventivas direcionadas aos portadores de BMR requerem a avaliação dos seguintes aspectos:

- percepção dos profissionais de enfermagem em relação ao risco de adquirirem infecção do portador de BMR ou de disseminá-la para outros pacientes no ambiente de trabalho (Percepção de Susceptibilidade);

- percepção dos profissionais de enfermagem sobre a gravidade destas doenças, se adquiridas (Percepção de Severidade);

- percepção das barreiras para adoção das medidas preventivas direcionadas aos portadores de BMR;

- percepção dos benefícios para adoção das medidas preventivas direcionadas aos portadores de BMR;

- a influência de fatores externos sobre o comportamento do indivíduo (estímulos para ação). 
De acordo com uma análise descritiva, pressupomos que os profissionais de enfermagem mais propensos a aderir às medidas preventivas direcionadas ao portador de BMR temem adquirir BMR e transmiti-la a outros pacientes, pois sabem que estão expostos a uma doença grave, com dificuldade ou impossibilidade de tratamento. Em vista disso, os profissionais atribuem que a adesão a essa prática apresenta mais benefícios do que barreiras. Também são relevantes, neste caso, as relações interpessoais, a influência da instituição e do comportamento pessoal e os estímulos para a ação. Coleta (2004), considera que,

[...] o pesquisador que se preocupar em saber como pensa cada indivíduo, se considerar as variáveis do MCS e incluir outras tão importantes e específicas ao estudo, estará no caminho certo para encontrar respostas para o problema de saúde que vem a ser a não adesão aos comportamentos de prevenção, tratamento ou controle das doenças.

Portanto, consideramos que a fundamentação teórica escolhida é adequada para melhorar a adesão às medidas preventivas de transmissão de infecção no ambiente hospitalar e que a elaboração de estratégias de intervenção bem sucedidas está diretamente relacionada ao conhecimento dos aspectos pressupostos pelo MCS que avalia a influência dos fatores subjetivos sobre o comportamento dos indivíduos. 


\section{OBJETIVOS}

\subsection{Geral}

Avaliar a adesão dos enfermeiros, técnicos e auxiliares de enfermagem às medidas preventivas na assistência a portadores de microrganismos multirresistentes internados no Hospital Geral de Passos - MG, com base no Modelo de Crenças em Saúde (MCS).

\subsection{Específicos}

1. Identificar o conhecimento dos profissionais de enfermagem de um Hospital Geral de Passos - MG a respeito das bactérias multirresistentes, com base no Modelo de Crenças de Rosenstock (1974a), considerando-se a:

• Percepção da susceptibilidade da doença pelo profissional;

- Severidade da doença;

• Influência da Instituição;

• Influência pessoal;

- Relação entre benefícios e barreiras;

2. Identificar as causas que determinam a adesão dos enfermeiros e auxiliares de enfermagem às medidas de precaução na assistência a portadores de microrganismos multirresistentes, segundo o seu conhecimento, assim como as causas que determinam a relação entre as barreiras e benefícios à adesão.

3. Identificar as causas que dificultam a adesão dos enfermeiros e auxiliares de enfermagem às medidas de precaução na assistência a portadores de microrganismos multirresistentes, segundo o seu conhecimento, como também as causas que dificultam a associação entre as barreiras e benefícios à adesão. 


\section{METODOLOGIA}

\subsection{Tipo de Pesquisa}

Este estudo do tipo descritivo transversal com a abordagem quali-quantitativa, foi realizado na Unidade de Clínica Médica (GI e GII) de um Hospital Geral de Passos - MG, cujos dados avaliamos qualitativa e quantitativamente.

\subsection{Local do Estudo}

\subsubsection{O Hospital Em Estudo}

O Hospital Geral de Passos - MG é um hospital geral destinado a prestar assistência hospitalar em quatro especialidades médicas básicas, quais sejam: clínica médica, clínica cirúrgica, clínica gineco-obstétrica e clínica pediátrica. Dispõe, ainda, dos serviços de hemodiálise, oncologia, UTI adulto e neonatal. Em relação à sua estrutura física, é um hospital horizontal multi-bloco, de grande porte (213 leitos), cujos serviços interligados acham-se distribuídos por edificações de médio porte. Presta assistência efetiva à população de uma grande área geográfica e atende a pelo menos 33 cidades da região, sendo sua clientela constituída predominantemente por usuários do Sistema Único de Saúde. A instituição possui um plano próprio de saúde, o Santa Casa Saúde, cujos conveniados constituem sua segunda demanda. Atende ainda a credenciados de diversos planos de saúde, assim como a clientes particulares.

Segundo o Estatuto da Irmandade do Hospital Geral de Passos - MG (1986), a instituição foi constituída por um grupo de cidadãos passenses e católicos, liderados por Jerônimo Pereira de Melo e Souza, Barão de Passos, em 1864. A Irmandade do Hospital Geral de Passos - MG é uma instituição civil, de caráter religioso-assistencial, filantrópica e 
caritativa, sem fins lucrativos. O Regulamento do Corpo Clínico tem como uma de suas finalidades estimular a pesquisa e o ensino do pessoal médico e paramédico.

O hospital é parte integrante de um sistema coordenado de saúde, que dispensa à comunidade completa assistência médica, preventiva, curativa, inclui-se serviços extensivos à família, em seu domicílio, e ainda treinamento médico, paramédico e de pesquisa.

A enfermagem organiza-se como Departamento de Enfermagem e faz parte da estrutura básica da Administração Executiva. A Coordenadora de Enfermagem tem sob sua responsabilidade um componente próprio de conhecimentos científicos e técnicos, construído e reproduzido por práticas sociais, éticas e políticas processadas pelo ensino, pesquisa e assistência. Dentre as Comissões do Corpo Clínico do hospital, destaca-se a Comissão de Controle de Infecção Hospitalar (CCIH) com seu respectivo Serviço de Controle de Infecção Hospitalar (SCIH) que é o órgão encarregado da execução das ações programadas, que consta no Regulamento do Corpo Clínico do Hospital Geral de Passos - MG,[198?].

\subsubsection{A Unidade Em Estudo}

As Unidades de Clínica Médica, identificadas como GI e GII, foram os locais onde desenvolvemos o estudo. Localizam-se no primeiro pavimento do prédio do Hospital Geral de Passos - MG e dispõem de um total de 62 leitos, distribuídos em 18 quartos, contendo cada um três leitos, disponibilizados exclusivamente para adultos com idade superior a treze anos. Cada quarto tem um banheiro, armário embutido e mesa de cabeceira. Quanto à distribuição dos quartos por sexo, esta fica sob a responsabilidade da Unidade de internação, que encaminha à GI a clientela masculina, ocupando os quartos de 130 a 139, e à GII a demanda feminina, cujos quartos vão de 140 a 152. 
A Unidade não possui quarto específico para isolamento com ante-sala e, nesse caso, improvisa-se colocando um suporte de roupas próximo à porta do quarto para pendurar o avental, diante da necessidade do uso do mesmo. Na indicação de isolamento, o paciente necessitará de quarto privativo, fato comunicado à enfermeira da Unidade pelo médico no ato da internação, porém se o diagnóstico for dado durante a sua internação, no caso de bactérias multirresistentes, rotineiramente o laboratório entra em contato com o médico do paciente e com o SCIH para agilizar o tratamento e as medidas preventivas, conforme já relatamos. A enfermeira chefe da Unidade, ao ser comunicada, empregará precauções de Isolamento, transferindo para outro quarto os pacientes que eventualmente estiverem ocupando os demais leitos do quarto. Desse modo, o paciente ficará isolado em seu próprio quarto, não havendo discriminação para escolha de local para alojá-lo e dois leitos ficarão vagos nesse quarto de isolamento; estes somente serão ocupados por portadores da mesma doença, isolamento por coorte.

Na porta do isolamento será colocado placa de “Procedimento", identificando o tipo de isolamento e a paramentação a ser utilizada nesse caso. Quanto às condutas a serem tomadas para pacientes portadores de bactérias multirresistentes, conforme tabela preestabelecida, orientada por Manuais e elaborada pelo SCIH, estas seguem o modelo instituído, conforme o protocolo descrito.

O quadro de pessoal de enfermagem da Unidade é constituído por uma enfermeirachefe para a GI e outra para GII, que atuam no período da manhã, por duas enfermeiras supervisoras, uma para o período da tarde e outra para noite, dois técnicos de enfermagem e 14 auxiliares de enfermagem para o turno da manhã; dois técnicos de enfermagem e 12 auxiliares de enfermagem para o turno da tarde e 15 auxiliares de enfermagem para o período da noite, totalizando quatro enfermeiras, quatro técnicos de enfermagem e 41 auxiliares de 
enfermagem. A jornada de trabalho desse pessoal é de 36 horas semanais, distribuídas nos turnos da manhã (6h45 às 15h15); tarde (14h45 às 23h15) e noite (22h45 às 7h15).

Nesta Unidade de Clínica Médica são internados os indivíduos com doenças infecciosas uma vez que o hospital não possui espaço físico próprio para estas internações.

É comum encontrarmos de três a quatro quartos fechados para isolamento, o que restringe o número de leitos disponíveis para internação na unidade. Cabe ressaltar que a média de ocupação de leitos no local foi de 98,33\% no ano de 2003 (SANTA CASA DE MISERICÓRDIA DE PASSOS, 2004) indicando a requisição constante de leito para internação.

\subsection{População e Amostra}

A população alvo foi formada por enfermeiros, técnicos e auxiliares de enfermagem do Hospital Geral de Passos - MG.

Para inclusão dos participantes, consideramos os seguintes critérios: estar lotado na Unidade de Clínica Médica (GI ou GII); pertencer à categoria profissional de enfermeiro, técnico ou auxiliar de enfermagem; aquiescer em participar do estudo; estar exercendo ativamente a função no período de coleta de dados. Quanto aos critérios de exclusão, estes incluíram os enfermeiros e auxiliares de enfermagem lotados em outras clínicas, e que estivessem fora do exercício ativo da profissão (férias, afastamento).

Assim, dispúnhamos de 49 profissionais de enfermagem lotados nas unidades de Clínica Médica, porém dois profissionais se recusaram a participar, três encontravam-se em férias e dois eram estagiários. Dessa maneira, a amostra ficou constituída por 42 profissionais de enfermagem, sendo quatro enfermeiros, dois técnicos e 36 auxiliares de enfermagem. 


\subsection{Aspectos Éticos e Legais}

Encaminhamos o projeto de pesquisa ao Comitê de Ética em Pesquisa da Escola de Enfermagem de Ribeirão Preto -Universidade de São Paulo, para apreciação, obtendo parecer favorável, conforme consta do protocolo nº 0363/2003 (ANEXO A).

Asseguramos aos participantes o anonimato, bem como nos comprometemos a comunicar à instituição os resultados da pesquisa, após sua conclusão.

\subsection{Coleta e Organização dos Dados}

\subsubsection{Instrumento para Coleta de Dados}

Para o desenvolvimento do presente estudo, o pesquisador elaborou um formulário semi-estruturado no qual anotou as respostas, face a face com o entrevistado. Para facilitar a compreensão, formulou perguntas claras, objetivas e precisas, em linguagem acessível e usual do informante. Os tipos de questões variaram entre fechadas, semi-abertas e abertas para facilitar as respostas do entrevistado e também para que este pudesse expressar o entendimento a respeito dessas experiências na sua própria linguagem (MINAYO, 1992).

O instrumento foi submetido ao julgamento de três juízes, profissionais considerados peritos no ensino, pesquisa e assistência em temas relacionados à infectologia, mais precisamente às medidas preventivas de controle de infecção hospitalar. Após análise e discussão das sugestões dos juízes, o pesquisador alterou o formulário e a sua versão final (ANEXO I) se constituiu em dois grandes grupos, além dos dados de identificação, quais sejam:

Grupo 1: Conhecimento sobre bactérias multirresistentes;

Grupo 2: Dimensão do Modelo de Crenças: 
- Percepção da susceptibilidade da doença pelo funcionário;

- Severidade da doença;

- Influência da instituição;

- Influência pessoal;

- Relação entre benefícios e barreiras.

\subsubsection{Estudo Piloto}

Após a validação do instrumento o pesquisador aplicou o estudo piloto em uma Unidade Cirúrgica, tendo entrevistado 20\% da totalidade dos sujeitos da amostra para avaliar o seu conteúdo e a coerência entre objeto e método, utilizando para esse fim uma sala de descanso da unidade. Posteriormente fez algumas alterações no instrumento para atender integralmente aos objetivos propostos.

\subsubsection{Procedimento para Coleta de Dados}

Realizamos as entrevistas somente após a assinatura, de todos os participantes, do termo de consentimento livre e esclarecido para sua participação no estudo. O pesquisador entrevistou os participantes em uma sala de descanso pertencente às unidades de Clínica Médica do Hospital Geral de Passos - MG, tendo cada entrevista a duração de 45 a 60 minutos, com média de 50 minutos. Para a coleta de dados, realizada no período de outubro a novembro de 2003, entrevistou os profissionais dos três turnos de trabalho (manhã, tarde e noite) cuja jornada era de oito horas diárias por turno.

Contamos com a colaboração da chefe de unidade para realização das entrevistas, entretanto a maior dificuldade encontrada foi a liberação do funcionário em determinados 
períodos, devido ao reduzido quadro da unidade para atender a grande demanda de atividades. Em determinados horários, a chefia não permitia a liberação dos funcionários, sendo então as entrevistas transferidas para horários em que a demanda de atividades local fosse menor. Contudo, queremos ressaltar a colaboração, o incentivo e o envolvimento das chefias das unidades, que procuraram facilitar o nosso trabalho, em todos os turnos.

Ao final da entrevista, a maioria dos profissionais revelaram que, apesar da entrevista ter sido extensa, cansativa, estavam satisfeitos por terem participado dela, uma vez que por seu intermédio puderam esclarecer dúvidas pertinentes ao isolamento, opinar e fornecer sugestões para melhoria do serviço, como também propiciará maior segurança não só para o profissional na atenção aos pacientes portadores de bactéria multirresistente como também para a instituição. O grande benefício deste contato foi a aproximação do pesquisador com o profissional, ato que causou maior envolvimento e cumplicidade entre as partes e despertou no profissional a intenção de melhorar o serviço prestado. Também foi positiva a possibilidade de reflexão sobre as condutas até então adotadas, o que reforçou e incentivou a participação efetiva dos profissionais na prevenção da aquisição e/ou disseminação das bactérias multirresistentes.

Ressaltamos, ainda, que além dos objetivos da pesquisa, os dados colhidos permitiram o esclarecimento de dúvidas dos profissionais a respeito de questões importantes, além de fornecerem sugestões de grande relevância para a execução eficiente dos procedimentos preventivos aos portadores de bactérias multirresistentes. Cremos que o envolvimento favoreceu ambas as partes, pois também passamos a compreender melhor o comportamento dos profissionais frente às diversas situações apresentadas. 


\subsubsection{Organização dos Dados}

Os resultados serão apresentados em três partes, a saber: Caracterização dos participantes do estudo, Conhecimento sobre as bactérias multirresistentes e dimensão do Modelo de Crenças de Rosenstock (1974a). Para a análise dos dados utilizamos o Método de análise de conteúdo de BARDIN (1977), e análise quantitativa de alguns dados, para a qual utilizamos estatística descritiva.

Analisamos as respostas abertas, considerando as etapas preconizadas por Bardin (1977), que se constituem de: leitura exaustiva das falas, pré-análise, exploração, tratamento e interpretação dos resultados. Neste trabalho apresentamos os dados de maneira descritiva e após a sua codificação, obtivemos categorização dos resultados.

A partir das perguntas fechadas constantes do formulário de entrevista tratamos os dados quantitativamente com base no cálculo de porcentagem, sendo os mesmos apresentados em tabelas. Para sua análise, baseamo-nos na adaptação de princípios da técnica de análise de conteúdo, modalidade temática (BARDIN, 1977; MINAYO, 1992).

“A análise de conteúdo é um conjunto de técnicas de análise das comunicações, visando obter, por procedimentos, sistemáticos e objetivos de descrição do conteúdo das mensagens, indicadores (quantitativos ou não) que permitam a inferência de conhecimentos relativos às condições de produção/recepção (variáveis inferidas) destas mensagens” (BARDIN, 1977). Quanto às técnicas de análise, estas auxiliam no detalhamento e na ordenação da aplicação das etapas e por meio delas podemos encontrar um rumo em meio aos caos que se forma, haja vista a grande quantidade de informações obtidas com a pré-análise, exploração do material, tratamento dos resultados, inferência e a interpretação.

O pesquisador analisou as falas dos profissionais com base na técnica de análise de conteúdo, que consiste em descobrir os núcleos de sentido que fazem parte da comunicação e 
cuja presença ou freqüência tem algum significado para os objetivos propostos para este trabalho. Segundo Minayo (1994), este tipo de metodologia serve tanto para a verificação de hipóteses ou questões formuladas, como também para confirmar ou não as afirmações estabelecidas durante o trabalho de campo.

Quanto à pré-análise, esta é a fase de organização propriamente dita. Esta primeira fase, geralmente, possui três missões: a escolha dos documentos a serem submetidos à análise, a formulação das hipóteses e dos objetivos e a elaboração dos indicadores que fundamentem a interpretação final.

Orientados por este método, desenvolvemos a pré-análise dos dados através da leitura flutuante, estabelecendo contato com os formulários e obtendo as nossas primeiras impressões.

Estabelecemos a escolha dos documentos de análise a priori, demarcando o universo a ser trabalhado, do qual faziam parte os formulários de entrevistas a que se submeteram os profissionais de enfermagem. Com o universo demarcado (o gênero de documentos) já pudemos iniciar a análise, mas às vezes é necessário elaborar a constituição de um corpus. O corpus é o conjunto de documentos que deve ser submetido aos procedimentos analíticos e a sua constituição e implica, muitas vezes em escolhas, seleções e regras, tendo Bardin (1977, p. 97-98), estabelecido como principais:

- $\quad$ Regra da exaustividade: uma vez definido o campo do corpus, é preciso terem em conta todos os elementos desse corpus. Esta regra é completada pela não-seletividade.

- $\quad$ Regra da representatividade: A análise pode efetuar-se numa amostra desde que o material a isso se preste. Nem todo o material de análise é susceptível de dar lugar a uma amostragem, e, nesse caso, mais vale absternos e reduzir o próprio universo, se este for demasiado importante.

- Regra da homogeneidade: Os documentos retidos devem ser homogêneos, quer dizer, devem obedecer a critérios precisos de escolha e não apresentarem demasiada singularidade fora dos critérios de escolha.

- $\quad$ Regra de pertinência: Os documentos retidos devem ser adequados, enquanto fonte de informação, de modo a corresponder ao objetivo que suscita a análise. 
Sendo assim, a constituição do corpus de análise não se referiu à seleção dos documentos, mas sim à manutenção dos documentos estabelecidos a priori, ou seja, todos os formulários de entrevistas contidos na amostra estabelecida.

Segundo Minayo (1992), o número adequado de entrevistas deve ser aquele capaz de refletir a totalidade nas suas dimensões. Portanto, o fato de a amostra desta pesquisa pertencer a uma unidade onde se realiza a maioria dos isolamentos por BMR, significa que estes refletirão a totalidade na dimensão desejada.

Os objetivos já haviam sido estabelecidos anteriormente pelo pesquisador, que efetuava as análises “às cegas” e sem idéias pré-concebidas, pois não é obrigatório ter-se como guia um corpus de hipóteses, para proceder a análise.

A referenciação dos índices procede a construção dos indicadores, e devendo determinar a realização de operações de pré-análise de recorte do texto em unidades comparáveis de categorização, para análise temática e de modalidade de codificação para o registro dos dados.

...... a categorização é um procedimento de separação de elementos
componentes de um todo, por diferenciação e por reagrupamento mediante
os critérios estabelecidos. As categorias são classes que reúnem um conjunto
de elementos (unidades de análise) sob um título genérico. Esse
agrupamento é feito considerando-se os aspectos comuns dos elementos.
Os critérios para categorização podem ser semântico ou temático, quando o
agrupamento contempla temas com significados semelhantes; léxico, refere-
se à classificação das palavras, considerando-se os significados; sintático
que congrega verbos e adjetivos e expressivos que classificam os vários
ruídos da fala.(GIR, 1997, p. 14)

Nesta investigação utilizamos a análise temática - quer dizer, da contagem de um ou vários temas ou itens de significação, numa unidade de codificação previamente determinada - apercebemo-nos de que se torna fácil a escolha, neste discurso, da frase (limitada por dois sinais de pontuação) como unidade de codificação:

Por enumeração temática, é possível levar a cabo, num texto, o levantamento das atitudes (qualidades, aptidões) , psicológicas aconselhadas ou desaconselhadas, que o leitor deve atualizar ou afastar de modo a poder chegar aos seus fins. Contam-se, assim, em cada unidade de codificação (neste caso, a frase), a qualidade ou o defeito presentes. (BARDIN, 1977). 
Nas categorias semânticas ou temáticas, as falas compuseram cada categoria, apresentando significados semelhantes, porém com conotações distintas, complementares ou até mesmo contraditórias. Assim, definimos, após o término da etapa, qual seria o nome de cada categoria.

Demos início à segunda fase com a exploração do material. Selecionamos as unidades de análise contidas em cada questão do formulário atribuindo-lhes codificação, tendo a definição dos códigos seguido a temática.

Organizamos os dados em um banco, processando-os nos programas Excel e Epiinfo, tratando-os através das porcentagens simples, média e moda, para procedermos a análise quantitativa.

Para realização da análise qualitativa, utilizamos a técnica de análise de conteúdo citada por Bardin (1977) e a interpretação deu origem às categorias e sub-categorias, analisadas com base no significado atribuído a elas, segundo Rosenstock (1974a).

Para tanto, agrupamos estas categorias de forma esquemática e representativa, conforme o modelo de crenças, quais sejam: percepções individuais, fatores modificadores e probabilidade de ação, fazendo assim a análise emergir dos dados. 


\section{APRESENTANDO E DISCUTINDO OS RESULTADOS}

\subsection{Caracterização dos profissionais de enfermagem}

No que se refere à caracterização dos 42 profissionais de enfermagem que participaram desta investigação, reunimos os dados apresentados na Tabela 1.

Tabela 1 - Distribuição dos profissionais de enfermagem $(\mathrm{N}=42)$ da Clínica Médica do Hospital Geral de Passos - MG, segundo categoria profissional, sexo, idade, tempo de serviço, turno e unidade de trabalho, 2003

\begin{tabular}{|c|c|c|c|}
\hline Variável & Classe & Freq. & $(\%)$ \\
\hline \multirow{3}{*}{ Categoria Profissional } & Enfermeiro & 4 & 9,5 \\
\hline & Auxiliar de Enfermagem & 36 & 85,7 \\
\hline & Técnico de Enfermagem & 2 & 4,8 \\
\hline \multirow{2}{*}{ Sexo } & Feminino & 33 & 78,6 \\
\hline & Masculino & 9 & 21,4 \\
\hline \multirow{6}{*}{ Idade } & $20 \mid-26$ & 8 & 19,0 \\
\hline & $26 \mid-31$ & 10 & 23,8 \\
\hline & $31 \mid-36$ & 8 & 19,0 \\
\hline & $36 \mid-41$ & 7 & 16,7 \\
\hline & $41 \mid-46$ & 5 & 11,9 \\
\hline & $46 \mid-50$ & 4 & 9,5 \\
\hline \multirow{5}{*}{ Tempo de Serviço } & $<1$ ano & 3 & 7,1 \\
\hline & $1 \mid-4$ & 15 & 35,7 \\
\hline & $4 \mid-7$ & 12 & 28,6 \\
\hline & $7 \mid-10$ & 3 & 7,1 \\
\hline & $10 \mid-$ & 9 & 21,4 \\
\hline \multirow{3}{*}{ Turno de Trabalho } & Matutino & 19 & 45,2 \\
\hline & Vespertino & 14 & 33,3 \\
\hline & Noturno & 9 & 21,4 \\
\hline \multirow[t]{2}{*}{ Unidade de Trabalho } & Clínica Médica Masculino GI & 22 & 52,4 \\
\hline & Clínica Médica Feminina GII & 20 & 47,6 \\
\hline
\end{tabular}


Participaram deste estudo três grupos de sujeitos, das seguintes categorias profissionais: enfermeiro, auxiliar de enfermagem e técnico de enfermagem. O grupo de auxiliares de enfermagem constituiu a principal categoria por representar $85,7 \%$ do total de sujeitos. A categoria de enfermeiros foi constituída por apenas quatro profissionais e, em menor proporção está a de técnicos de enfermagem (4,8\%).

No que se refere ao gênero, os trabalhadores eram predominantemente do sexo feminino, com $33(78,6 \%)$ dos profissionais enquanto o masculino somou 09 (21,4\%).

Quanto ao tempo de serviço houve variação entre dois meses e 28 anos; predominou o período de 01 e 03 anos (35,7\%), seguido de 04 a 06 anos de serviço $(28,6 \%)$, sendo que a terceira maior categoria foi a de profissionais com mais de 10 anos de serviço (21,4\%). Portanto, predominaram os profissionais com tempo de serviço entre 01 e 06 anos na instituição (64,3\%), seguido dos que trabalham há mais de 10 anos $(21,4 \%)$, e, por último, os recém-contratados, $(7,1 \%)$, indicando que uma população predominantemente jovem convive diariamente com trabalhadores com muitos anos de experiência no serviço (acima de 10 anos).

A idade do grupo variou de 21 a 50 anos e as faixas etárias predominantes foram de 20 a 35 anos, onde localizamos 26 (61,9\%) profissionais de enfermagem. A categoria, com menor freqüência, contemplou os profissionais com a faixa etária entre 46 e 50 anos (9,5\%). A média foi de 32 anos de idade.

O local de trabalho de 22 (52,4\%) entrevistados era a unidade de Clínica Médica Masculina e de outros 20 (47,6\%), a unidade de Clínica Médica Feminina, verificando-se proporções semelhantes de trabalhadores. 


\subsection{Conhecimento dos profissionais de enfermagem acerca das Bactérias}

\section{Multirresistentes}

\subsubsection{Causas da multirresistência bacteriana}

Os 42 profissionais de enfermagem ao serem questionados sobre o motivo pelo qual as bactérias ficam multirresistentes, os 42 entrevistados emitiram 55 respostas, conforme demonstrado na Tabela 2, sendo que em 27 (49,1\%) respostas atribuíram a resistência à utilização indiscriminada de antibióticos, seja pelo uso abusivo, inadequado ou prolongado. Ainda mencionaram a permanência do paciente no hospital (14,5\%) e uso de antibióticos de forma geral $(9,1 \%)$; a falta de identificação do agente etiológico para iniciar o tratamento (7,3\%); a falta de lavagem das mãos (5,5\%) e outros fatores (3,6\%), dentre eles, a baixa imunidade do paciente, os tratamentos incompletos e a auto-medicação. Houve ainda uma resposta em que mencionou a colonização de sondas e feridas e outra na qual não soube responder à pergunta, por não ter conhecimento específico do assunto.

Tabela 2 - Distribuição das respostas atribuídas pelos profissionais de enfermagem, relacionadas ao motivo da resistência bacteriana na Unidade de Clínica Médica do Hospital Geral de Passos - MG -MG, 2003

\begin{tabular}{lcc}
\hline \multicolumn{1}{c}{ Motivo da resistência bacteriana } & Freq. & (\%) \\
\hline uso indiscriminado de antibióticos & 27 & 49,1 \\
longa permanência do paciente & 8 & 14,5 \\
uso de antibióticos & 5 & 9,1 \\
falta de identificação do agente etiológico para iniciar tratamentos & 4 & 7,3 \\
(cultura) & 3 & 5,5 \\
falta da lavagem das mãos & 2 & 3,6 \\
baixa imunidade & 2 & 3,6 \\
tratamentos incompletos & 2 & 3,6 \\
auto medicação & 1 & 1,8 \\
não sabe o motivo & 1 & 1,8 \\
colonização de sondas e feridas & 55 & 100 \\
\hline Total & &
\end{tabular}


Rodrigues et al. (1997) referem que a resistência bacteriana aos antibióticos, atualmente, é crescente, devido à dependência da pressão seletiva imposta às populações bacterianas. Embora a resistência possa ser considerada como uma conseqüência natural do uso de antibióticos, na realidade ela tem sido associada à intensa e extensa utilização desses medicamentos, muitas vezes inadequada e abusiva. Hoje em dia, já não são tão excepcionais os pacientes acometidos por infecções para as quais existam poucas, por vezes nenhuma, alternativas terapêuticas.

Para exercer sua ação o antibiótico deve atingir alvos definidos existentes nas bactérias; então, a resistência bacteriana a antibióticos reflete a capacidade das bactérias em evitar esta ação inibitória ou letal. A avaliação preliminar in vitro dos antibióticos revelará existência de bactérias sensíveis e de outras naturalmente resistentes; assim, inicialmente a resistência pode ser categorizada intrínseca e adquirida. A resistência intrínseca é um atributo inerente de uma particular espécie bacteriana a um determinado antibiótico; ela pode depender da presença de barreiras naturais que evitam que o antibiótico alcance seu alvo ou da inexistência do alvo apropriado sensível à ação do antibiótico. Já a resistência adquirida reflete uma verdadeira mudança genética na bactéria tal que o antibiótico até então ativo, não o é mais. Fala-se em tolerância quando o antibiótico, embora permanecendo a bactéria sensível, deixa de ter uma ação bactericida, a qual passa a ser bacteriostática; ou seja, a concentração que antes era MBC (concentração bacteriostática mínima), agora é apenas MIC (concentração inibitória mínima).

A pressão seletiva sobre as bactérias, decorrente do uso dos antibióticos, pode resultar em: a) eliminação da população bacteriana sensível e emergência da que já era normalmente (intrinsecamente) resistente; b) crescimento de cepas previamente sensíveis, mas que adquiriram resistência (quer seja por mutação, dando origem a um clone mutacional, quer seja pela aquisição de material genético exógeno codificador da resistência) (Rodrigues et al, 1997, p.561-562).

A existência de microrganismos multirresistentes em áreas críticas, como na Unidade de Terapia Intensiva (UTI), principalmente, deve-se a uma série de fatores, dentre eles: características dos pacientes, presença de doenças, idade e procedimentos invasivos associados. Pacientes de UTI, costumeiramente, têm uma série de ameaças às suas defesas. Tais ameaças podem ser decorrentes de doenças debilitantes, como o câncer, de doenças pulmonares e cardíacas, ou ainda pelo fato de o paciente ser idoso ou ter sofrido intervenções, tais como cirurgias, cateterismo, sondas, drenos etc., sendo que estes pacientes podem já 
chegar ao hospital infectados ou terem desenvolvido infecções na própria UTI (MACHADO, 2003).

Quando ocorre a quebra de defesas do paciente, é necessário um uso mais intenso e mais agressivo de antibióticos do que em outras circunstâncias, devido às características críticas do paciente. Assim, os microrganismos da UTI convivem num ambiente repleto de antibióticos, desenvolvendo mecanismos de defesa e se adaptando ao ambiente, ocorrendo, então, uma grande pressão seletiva de resistência. Podemos dizer que, dentro das UTI, existe um grupo de bactérias mais resistentes com capacidade crescente de se defenderem dos tratamentos e com isso temos cada vez menos recursos para tratar estas infecções (Machado, 2003).

Souza Filho (2003) relata que o uso de antimicrobianos tem sido identificado como um dos mais importantes fatores de emergência na prevenção (ou no tratamento) das infecções bacterianas multirresistentes, sobretudo nas UTI, porque existe uma associação entre uso prévio de antibióticos e o aparecimento de germes multirresistentes.

Estudo realizado em enfermaria e UTI pediátricas de um hospital de ensino terciário, teve como objetivo identificar os fatores de risco em pacientes cujo diagnóstico era infecção ou colonização por bactérias multirresistentes. Para tanto, os autores pesquisaram os seguintes fatores de risco: internação anterior, diagnóstico de doença crônica, internação em UTI, procedimento cirúrgico, uso de sonda vesical de demora, cateter venoso central, respirador, antibióticos e presença de solução de continuidade da pele. Os resultados da análise de regressão logística do estudo caso-controle, apresentaram como fatores significativos apenas o uso prévio de antibióticos e a presença de solução de continuidade da pele, porém para os pacientes com bactérias gram-negativas multirresistentes foi significativo apenas o resultado de solução de continuidade da pele. A conclusão foi que o uso de antibiótico e a presença da solução de continuidade da pele estavam relacionados à aquisição de bactérias 
multirresistentes, enquanto que, para os pacientes colonizados com Staphylococcus aureus resistentes à oxacilina, a presença de cateter venoso central também constituiu-se num fator de risco (TRESOLDI et al., 2000).

Além destes aspectos, segundo a OMS (2000), também contribuem com a resistência microbiana os seguintes fatores: paradigma da pobreza, acesso inadequado aos medicamentos, erro diagnóstico, medicamentos falsificados, preferência por antibióticos de largo espectro, publicidade que pressiona os pacientes a utilizarem novas drogas, deficiências na formação dos profissionais de saúde, alimentos originários de animais com BMR, e, ainda, a globalização, devido às viagens internacionais ao intercâmbio comercial e, finalmente, a resistência em hospitais à qual está associada a desatenção com as técnicas apropriadas para o controle de infecção.

Em relação aos fatores evidenciados, podemos citar o estudo de Seiscento et al.(1997), sobre tuberculose multirresistente (TBMR). Os autores avaliaram os aspectos clínicolaboratoriais, epidemiológicos e terapêuticos de 70 portadores de TBMR, obtendo como resultado mais freqüente o abandono ao tratamento (54,3\%), seguido da recidiva após a cura e falência no tratamento (14,3\%), intolerância às drogas $(11,4 \%)$ e contato com TBMR (8,6\%). Em 11\% não foi possível determinar o fator preditor de risco, sendo que a multirresistência adquirida foi encontrada em $80 \%$ dos casos e a primária, em apenas 8,6\% deles.

Neste estudo, apesar das respostas obtidas estarem corretas, em sua maioria, quando perguntados sobre os motivos pelos quais as bactérias ficam multirresistentes, diversos fatores não foram lembrados pelos profissionais entrevistados ou eles não têm conhecimento deles. Constatamos que eles têm conhecimento, correto porém limitado, acerca dos motivos que podem levar as bactérias a ficarem multirresistentes. 


\subsubsection{Riscos para a equipe de saúde}

Quando questionados se um paciente com BMR oferecia algum risco para a equipe de saúde, 41 (97,6\%) responderam positivamente e apenas um (2,4\%) profissional negou que as BMR podem representar riscos à equipe. O tipo de risco mais citado foi a "contaminação”, com 34 (81\%) respostas; apenas um (2,4\%) mencionou a propagação das doenças e sete (16,7\%) profissionais não souberam responder a quais riscos estavam expostos.

Assim, consideramos que a contaminação seja o maior risco, porque a colonização propicia mais facilmente a infecção, com grande ênfase nas precauções aplicadas a portadores de BMR, segundo as orientações contidas nos Guidelines dos CDC (1999).

Em vigência de um surto por MRSA, a instituição faz uma avaliação epidemiológica para conhecer os fatores de risco para aquisição de MRSA, buscando identificar os pacientes colonizados ou infectados o mais rapidamente possível, para que as precauções relacionadas às barreiras sejam tomadas. Nessas situações, o pessoal da equipe deve higienizar as mãos antes e após os contatos com os pacientes, instituindo-se, assim, a barreira de transmissão para impedir o contato do portador com o paciente. $\mathrm{O}$ portador que está ligado epidemiologicamente à transmissão não deve receber os cuidados diretos até que o seu tratamento apresente resultado bem sucedido (CDC,1996).

Bоyce (2001) também faz referência às medidas propostas para o controle do staphylococcus aureus resistente a metilcilina (MRSA), considerando como necessária a: vigilância prospectiva microbiológica para identificar pacientes colonizados; o isolamento dos pacientes colonizados ou infectados; as barreiras de precaução, como luvas e avental; a lavagem e anti-sepsia das mãos da equipe; a limpeza cuidadosa dos quartos; o controle da prescrição dos antibióticos de amplo espectro e o tratamento dos pacientes colonizados ou infectados e dos profissionais de saúde envolvidos em surtos. 
Contudo, não encontramos nenhuma investigação que tratasse da infecção do profissional da equipe de saúde contraída através do contato com o portador de BMR. Existem relatos de aquisição da tuberculose via ocupacional, embora sem qualquer citação da presença de cepa multirresistente adquirida em ambiente hospitalar

Takeda; Robazzi e Lavrador (2001) pesquisaram o risco ocupacional relacionado à transmissão da tuberculose entre os trabalhadores de enfermagem hospitalar e obtiveram como resultados, que em um ano, os trabalhadores apresentaram risco 3,86 vezes maior e num outro 1,47 vezes maior de adquirirem a doença. Neste estudo, a tuberculose foi considerada como um risco ocupacional para os trabalhadores de enfermagem.

Com o aumento dos casos de tuberculose multirresistente é evidente que o profissional também está exposto a esse risco. Rabahi e Almeida Netto (2001) estudaram o risco ocupacional entre profissionais de saúde pelo fato de, nos últimos anos, estarmos enfrentando o desafio dessa doença, como contaminação intra-hospitalar com risco aumentado de infecção dos profissionais de saúde além do surgimento de cepas multirresistentes. Quanto às respostas dadas em relação ao conhecimento dos profissionais sobre o risco que corriam pela exposição ao cuidarem dos portadores de BMR, 35 (83,4\%) responderam corretamente, indicando que conheciam esses riscos, enquanto 7 (16,7\%) referiram desconhecê-los, indicando que este, possivelmente, seja o motivo de menor adesão às medidas preventivas na assistência a portadores de BMR. 


\subsubsection{Localização das BMR no organismo humano}

Com relação à localização das BMR no organismo do paciente, 08 (6,6\%) dos entrevistados alegaram que elas podem estar presentes em qualquer parte do corpo humano, bem como nas excreções e secreções dos pacientes; 25 (20,7\%) citaram o aparelho respiratório, 18 (14,9\%) a corrente sangüínea, 14 (11,6\%) as excreções e 14 (11,6\%) a pele. Também obtivemos outras respostas em menores proporções (tabela 3), indicando as secreções, 08 (6,6\%); feridas infectadas, 07 (8,8\%); aparelho digestivo, 05 (4,1\%); regiões úmidas, 05 (4,1\%); mucosas, 05 (4,1\%); trato geniturinário, 03 (2,5\%); olhos, 03 (2,5\%); ponta de cateter, 02 (1,7\%); unhas, 02 (1,7\%); pêlos, 01 (0,8\%); e incisão cirúrgica, 01 (0,8\%), como referido da Tabela 3 .

Tabela 3 - Distribuição das respostas atribuídas pelos profissionais de enfermagem, relacionadas à localização das bactérias multirresistentes no organismo do paciente na Unidade de Clínica Médica do Hospital Geral de Passos - MG, 2003

\begin{tabular}{|c|c|c|}
\hline Localização das BMR & Freq. & (\%) \\
\hline aparelho respiratório & 25 & 20,7 \\
\hline corrente sanguínea & 18 & 14,9 \\
\hline excreções & 14 & 11,6 \\
\hline pele & 14 & 11,6 \\
\hline todas ( e quaisquer ) as partes do corpo & 8 & 6,6 \\
\hline secreções & 8 & 6,6 \\
\hline feridas infectadas & 7 & 5,8 \\
\hline aparelho digestivo & 5 & 4,1 \\
\hline regiões úmidas ( axilas, períneo ) & 5 & 4,1 \\
\hline mucosas & 5 & 4,1 \\
\hline trato geniturinário & 3 & 2,5 \\
\hline olhos & 3 & 2,5 \\
\hline ponta de cateter & 2 & 1,7 \\
\hline unhas & 2 & 1,7 \\
\hline pêlos & 1 & 0,8 \\
\hline incisão cirúrgica & 1 & 0,8 \\
\hline total & 121 & 100 \\
\hline
\end{tabular}


Somente aqueles que se referiram a todas as partes do corpo 08(6,6\%), responderam adequadamente. Os demais, 34 (93,4\%) possuem uma visão parcial sobre as localidades em que estas bactérias podem ser encontradas, portanto responderam incorretamente. Estes também não fizeram qualquer referência ao fato de que alguns sítios do corpo são mais freqüentemente colonizados por espécies específicas de bactérias.

Fernandes (2000), descrevendo o ser humano como "habitat" para microrganismos, afirma que só o útero está livre de microrganismos, quando apresenta condições normais de gestação e enquanto as estruturas placentárias permanecerem intactas, providenciando uma barreira à entrada de germes. À partir da ruptura da bolsa, o bebê entra em contato com a microbiota materna e, gradativamente, com microrganismos de outras pessoas, de objetos inanimados e do ambiente e, ao final da segunda semana de vida, a microbiota semelhante à dos adultos já está estabelecida, sendo conhecida como “microbiota normal”. A sua supressão gera um vazio no nicho ecológico, rapidamente preenchido por microrganismos ambientais ou de outras topografias do hospedeiro, os quais podem atuar como germes oportunistas ou até mesmo patogênicos. Mudanças na microbiota humana normal podem ocorrer em pacientes hospitalizados, principalmente na faringe, pele, vagina e intestino. E o uso de antibióticos em pacientes internados propicia o vazio no nicho ecológico, concorrendo para a colonização por bactérias multirresistentes do ambiente hospitalar.

Rodrigues et al. (1997) citam as bactérias mais predominantes nas infecções hospitalares, assim como a sua localização, ou seja:

- Staphylococcus aureus: localizadas no próprio corpo e nas mãos do paciente, colonizam mais freqüentemente a região anterior das fossas nasais, o trato respiratório superior, as alterações da pele (ferida cirúrgica, queimadura, úlcera de decúbito, traqueostomia, gastrostomia), períneo e reto. 
- Stafilococcus coagulase-negativa e Enterococcus: são um dos maiores componentes da microbiota normal do ecossistema cutâneo, colonizando a pele e a membrana mucosa.

- Enterobactérias: trato gastrointestinal e orofaringe.

- Bacilos Gram-negativos não-fermentadores: no homem coloniza o períneo, axilas e ouvidos.

Fernandes (2000) cita, ainda, as bactérias mais comuns e os seus sítios de preferência:

- Staphylococcus aureus: mucosa nasal e pele.

- Staphylococcus epidermidis: mucosa nasal e pele.

- Enterococcus: na espécie humana habita os tratos gastrointestinal, hepatobiliar e geniturinário, colonizando eventualmente a pele, na região do períneo e, transitoriamente, as mãos da equipe de saúde.

- Enterobactérias: freqüentemente habitam o intestino, mas podem colonizar e até infectar gravemente todos os órgãos do corpo humano, principalmente trato urinário, vias aéreas, ferida cirúrgica, causando infecções sistêmicas e infecções do sistema nervoso central.

- Coco-bacilos Gram-negativos não-fermentadores (Acinetobacter): colonizam persistentemente a pele humana, principalmente dobras. O complexo A. calcoaceticus/ A.baumannii é encontrado na pele de até $25 \%$ das pessoas sadias, albergando-se na cavidade oral de até 7\% destas, aumentando em pacientes hospitalizados e profissionais de saúde.

Portanto, as bactérias podem estar presentes em qualquer parte do organismo do paciente e, de acordo com a espécie, elas têm preferência por uma determinada localização. 


\subsubsection{Microrganismos mais comumente encontrados no ambiente hospitalar}

As espécies mais comumente encontradas em pacientes da Clínica Médica do hospital do estudo, segundo os profissionais de saúde, foram: MARSA 37 (29,1\%), Pseudomonas 35 (27,6\%) e os Staphylococus 23 (16,1\%), bacilo de Kock 15 (11,8\%), as quais prevaleceram consideravelmente sobre as demais espécies, conforme Tabela 4.

A realidade no entanto apresenta uma situação um tanto diferente, uma vez que conforme dados fornecidos pelo SCIH do mesmo hospital, no ano de 2003, foram isolados em sete casos de infecção hospitalar, ocorridos na Unidade de Clínica Médica do Hospital Geral de Passos - MG, demonstrando predominância de Pseudomonas aeruginosa 04 (57,14\%), Pseudomonas sp 2 (28,57\%), Acinetobacter 01 (14,29\%) multirresistentes (SCIH, 2003).

Tabela 4 - Distribuição das respostas atribuídas pelos profissionais de enfermagem, relacionadas aos microrganismos citados como comumente encontrados na Unidade de Clínica Médica do Hospital Geral de Passos - MG, 2003

\begin{tabular}{lcc}
\hline \multicolumn{1}{c}{ Microrganismos citados pelos profissionais } & Freq. & (\%) \\
\hline Staphylococcus aureus metilcilina resistente & 37 & 29,1 \\
Pseudomonas sp. & 35 & 27,6 \\
Staphylococcus sp. & 23 & 18,1 \\
Bacilo de Kock & 15 & 11,8 \\
Acinetobacter sp. & 7 & 5,5 \\
Vírus da Imunodeficiência Humana (HIV) & 7 & 5,5 \\
Streptococcus sp. & 1 & 0,8 \\
Escherichia coli & 1 & 0,8 \\
Não respondeu & 1 & 0,8 \\
\hline Total & 127 & 100 \\
\hline
\end{tabular}

Observamos que o conhecimento dos profissionais a respeito das bactérias multirresistentes isoladas no hospital, demonstrado na Tabela 4, de maneira geral, não existe, uma vez que eles relataram desconhecer esta informação.

No hospital como um todo, há registro (SCIH, 2003) de 38 casos de infecção hospitalar causados por microrganismo multirresistentes: em 14 (36,8\%) casos foram isolados 
Pseudomonas aeruginosa multirresistente, 9 (23,7\%) Acinetobacter sp multirresistente, 5 (13,2\%) Staphylococcus epidermidis metilcilina resistente, 4 (10,5\%) Pseudomonas sp multirresistente, 2 (5,3\%) Klebsiella sp multirresistente, 2 (5,3\%) Staphylococus coagulase negativa metilcilina aminoglicosídeo resistente e 2 (5,3\%) Staphyloccus aureus metilcilina aminoglicosídeo resistente (SCIH,2003).

Portanto, eles demonstraram conhecer algumas espécies de microrganismos encontradas na microbiota hospitalar da instituição do estudo , citando com maior freqüência o MARSA (29,1\%)e Pseudomonas (27,6\%). A esse respeito, pudemos observar na entrevista que eles conheciam o MARSA somente pelo rótulo, desconhecendo tratar-se de um staphylococcus metilcilino aminoglicosídeo resistente, tanto que escreviam MARSA incorreta mente, comprovando que desconheciam o significado de cada letra da sigla.

Em relação às demais espécies, o conhecimento mostrou-se restrito: staphylococcus, 23 (16,1\%); bacilo de Kock, 15 (11,8\%); Acinetobacter, 7 (5,5\%); 7 (5,5\%) mencionaram o vírus HIV e 01 (0,8\%), o streptococcus e também a Escherichia. Quanto às bactérias isoladas nas infecções hospitalares em geral, estas sequer foram mencionadas, o que demonstra o desconhecimento dos profissionais a respeito da situação epidemiológica local, configurandose como um fator negativo, por se tratar de um quesito de prevenção, ou seja, a vigilância prospectiva dos resultados de cultura e antibiograma.

\subsubsection{Pacientes mais susceptíveis à colonização por BMR}

Quando interrogados sobre a existência de paciente mais susceptível à colonização por BMR, em nível hospitalar, os profissionais de enfermagem foram unânimes em responder afirmativamente, porém ao serem consultados sobre quais eram estes indivíduos, 42 (47,2\%) referiram-se aos pacientes que se encontravam com baixa imunidade,os imunossuprimidos, 18 
(20,2\%) incluíram nesta categoria os portadores de HIV; 8 (9,0\%), os debilitados e idosos; 7 (7,9\%), os que se encontravam em pós operatório; 7 (7,9\%), aqueles com procedimentos invasivos; 6 (6,7\%) os pacientes internados em áreas críticas (unidade de queimados, diálise, UTI); 4 (4,5\%) as internações de tempo prolongado; 3 (3,4\%) aqueles em uso de antibióticos e $1(1,1 \%)$ os usuários de drogas endovenosas, conforme Tabela 5.

Tabela 5 - Distribuição das respostas atribuídas pelos profissionais de enfermagem, relacionadas a pacientes mais susceptíveis a colonização por BMR na unidade de Clínica Médica do Hospital Geral de Passos - MG, 2003

\begin{tabular}{lcc}
\hline \multicolumn{1}{c}{ Pacientes mais susceptíveis à colonização por BMR } & Freq. & (\%) \\
\hline imunossuprimidos & 42 & 47,2 \\
debilitados / idosos & 18 & 20,2 \\
pós-operatório & 8 & 9,0 \\
com procedimentos invasivos & 7 & 7,9 \\
pacientes de áreas críticas & 6 & 6,7 \\
tempo de internação prolongado e/ou freqüentes & 4 & 4,5 \\
uso de antibióticos & 3 & 3,4 \\
usuário de drogas endovenosas & 1 & 1,1 \\
\hline Total & 89 & 100 \\
\hline
\end{tabular}

O conhecimento geral dos participantes mostrou-se adequado, contudo, analisando-os individualmente, concluímos que o conhecimento dos 42 (100\%) profissionais de enfermagem entrevistados está associado à baixa imunidade, e que a maioria desconhece os demais fatores. Este fato é extremamente preocupante, visto que a percepção individual desses indivíduos está comprometida devido ao desconhecimento de fatores importantes.

Estudando as infecções em pacientes imunossuprimidos sem Síndrome da Imunodeficiência Adquirida (AIDS), Velasco e Martins (1994) consideraram que os pacientes imunocomprometidos apresentavam risco diferenciado de infecções, tanto relacionado a doenças de base quanto a intervenções diagnósticas e terapêuticas. A infecção - e não a patologia primária - tornou-se a principal causa de morbidade e mortalidade nesse grupo de 
pacientes, além desta, também as freqüentes hospitalizações contribuíram para aumentar o alto risco de os pacientes desenvolverem processos infecciosos oportunísticos e por microrganismos multirresistentes, indicando, obviamente, tratar-se de um tipo de paciente mais susceptível.

Starling e Silva (1998a) referem-se à existência de um grupo de pacientes com altas taxas de colonização, quais sejam: pacientes de diálise (IR crônica); usuários de drogas endovenosas; indivíduos com doenças dermatológicas crônicas (eczema, por exemplo) e indivíduos com diabetes mellitus insulino dependente. Assim, em nível hospitalar há grupos especiais com risco aumentado de colonização por BMR (MARSA/MARSE Staphylococcus aureus metilcilino aminoglicosídeo resistentes, ou Staphylococcus epidermidis metilcilino aminoglicosídeo resistentes). Em unidades de queimados e de tratamento intensivo, por exemplo, os fatores especificamente associados a essa colonização, são: hospitalização prolongada; antibioticoterapia prévia; doença de base severa; pacientes mais susceptíveis à aquisição de infecção hospitalar devido à quebra de defesas; os portadores de doenças debilitantes, de câncer, doenças pulmonares e cardíacas, os pacientes idosos e os que sofreram intervenções cirúrgicas, cateterização ou mesmo aqueles que já chegaram infectados; submetidos a procedimentos de risco realizados no hospital e os com baixa resistência ou que recebem cuidados de profissionais com mãos contaminadas.

Os fatores de risco para colonização ou infecção por MARSA, nos hospitais, são: hospitalização prolongada, uso de antibiótico de largo espectro, internação em unidade de terapia intensiva ou de queimados e proximidade de um paciente colonizado ou infectado. Aparentemente, a restrição ao leito, isto é, a dependência total do paciente à equipe de saúde, também constitui fator de risco para aquisição de MARSA, sem contar que o uso prévio de antibióticos tem sido fortemente correlacionado ao MARSA, em todos os estudos. Segundo 
Rodrigues et al. (1997), alguns fatores tornam os pacientes mais susceptíveis à colonização e estes variam de acordo com o tipo de microrganismo colonizante conforme descrito abaixo:

Stafilococcus coagulase-negativa e Enterococcus: colonizam pacientes com uso de implantes vasculares ou extravasculares ou de antibióticos; tempo de hospitalização (internação prolongada); doença subjacente; maior sobrevida de imunodeprimidos, como RN de baixo peso e pacientes com diagnóstico de neoplasia, em especial os neutropênicos, em uso de quimioterapias; maior valorização dos resultados de culturas, pois antigamente estes eram considerados contaminação e não eram tratados como atualmente.

Enterobactérias: Em decorrência de vários tipos de “stress”, surgem em pacientes com doenças crônicas de base (diabetes, renais crônicos, etc.), idosos, imunocomprometidos e pacientes submetidos a procedimentos invasivos; pacientes gravemente debilitados; antibioticoterapia; transmissão através das mãos de profissionais de saúde, de superfícies inanimadas, de equipamentos, pelo contato direto de um paciente com outro colonizado e/ou infectado; ingestão de água, alimentos, especialmente saladas cruas, dietas enterais e líquidos de infusão contaminados; artrópodes; intra-útero (outra forma de contaminação).

Bacilos Gram-negativos não-fermentadores: colonizadores de pacientes portadores de leucemia e naqueles com internações prévias; hospitalização; pele de queimados; trato respiratório de pacientes submetidos à ventilação mecânica; trato gastrointestinal de pacientes em quimioterapia; uso de antibióticos; pacientes gravemente enfermos (UTI, berçário de alto risco, unidade de queimados e unidade de câncer); portadores de leucemia e fibrose cística (neoplásicos); em procedimentos invasivos, como cirurgias, traqueostomia, CVC, cateterismo urinário, ventilação mecânica, nutrição parenteral prolongada; associação ao uso de drogas terapêuticas como antibióticos, antineoplásicos e corticosteróides; colonização prévia.

Mycobacterium tuberculosis: procedem de contatos íntimos; em pessoas (HIV(+); em usuários de drogas IV; em indivíduos com fatores de risco (sabidos como favorecedores de 
adoecimento em pessoas infectadas); em residentes e funcionários de instituições que segregam as pessoas; em profissionais de saúde que cuidam de pacientes de risco elevado; em populações pobres e com precária assistência de saúde; em lactantes, crianças e adolescentes expostos a adultos que se enquadram nas categorias de risco elevado.

Buscando avaliar a ocorrência de colonização intestinal em recém-natos por cepas de enterobactérias multirresistentes a antimicrobianos (CEMA) no curso da hospitalização, Vieira et al. (1999) estudaram a inclusão seqüencial de 30 recém-nascidos internados no berçário do HUPE-UERJ, hospital universitário público e terciário que disponibiliza 600 leitos. Os autores detectaram 56 cepas de enterobactérias multirresistentes a antimicrobianos em 14 dos 30 recém-nascidos estudados (46,7\%), sendo Klebsiella pneumoniae a espécie bacteriana mais freqüentemente isolada (68\%). Constatou, ainda, a associação entre o isolamento de CEMA e a presença de 3 ou 4 dos seguintes fatores de risco para a colonização: uso de antimicrobianos, baixo peso $(<2500 \mathrm{~g})$, hospitalização por mais de 6 dias e alimentação com leite artificial $(\mathrm{p}<0,02)$. Concluindo uma alta freqüência de colonização intestinal de recém-nascidos hospitalizados por espécies de enterobactérias multirresistentes.

Góngora (1999) propôs-se a estudar os fatores de risco de colonização por bacilos gram-negativos multirresistentes na orofaringe de pacientes internados em unidade de terapia intensiva clínico-cirúrgica, por se tratar de um local que apresenta maiores taxas de incidência de pacientes colonizados-infectados e o epicentro do desenvolvimento da resistência bacteriana. Todos os pacientes submeteram-se à coleta de swab da orofaringe posterior no primeiro dia de internação , no terceiro dia e a cada sete dias até a alta ou óbito. Participaram deste estudo 430 pacientes, sendo que 113 (26,3\%) deles foram colonizados e 317 ( 73,7\%) não. Dos 113 casos, 53 (46,9\%) já estavam colonizados no terceiro dia de internação. 


\subsubsection{Modo de transmissão das bactérias multirresistentes}

Quanto ao modo de transmissão das BMR, ela ocorre de um indivíduo a outro, como as demais bactérias, ou seja, através do contato direto, indireto, via aérea, gotículas infectantes (respiratória), visitantes, ou de veículo comum contaminado (água, medicamentos, alimentos), porém de acordo com as diversas espécies encontradas, alguns tipos de transmissão são mais freqüentes, como veremos a seguir.

Rodrigues et al. (1997) relacionam as formas mais freqüentes de transmissão das doenças:

Através de paciente colonizado ou infectado que atua como reservatório; paciente colonizado recebido de outra instituição; introdução através de um profissional de saúde colonizado ou infectado disseminando diretamente é menos comum. Na maioria dos surtos onde o pessoal de saúde foi considerado reservatório, geralmente havia colonização em áreas de dermatite, além da colonização nasal. Um estudo revelou que um fisioterapeuta, portador de sinusite crônica causada por uma cepa epidêmica de Staphylococcus aureus metilcilino resistente (MRSA) foi o principal reservatório e transmissor de um surto. Quanto às superfícies ambientais, como reservatórios, estas geram controvérsias, sendo mais freqüentemente positivas: as camisolas dos pacientes (33\%), chão (40\%), roupas de cama (26\%), aparelhos de pressão (26\%) e mesas para alimentação dos pacientes (20\%). Uniformes ou capotes utilizados pela equipe de enfermagem, durante as atividades intensas com estes pacientes, freqüentemente tornam-se contaminados. No caso de contaminação de um paciente para o outro, ela pode ocorrer principalmente pelas mãos da equipe de saúde ou quando os pacientes ajudam-se mutuamente; quanto à transmissão pelo acompanhante, esta não foi estudada. Outras transmissões, como a que ocorre pelo ar foi considerada muito menos importante que pelo contato direto; pacientes ou pessoal de saúde com dermatite apresentam 
risco aumentado não só de adquirir, como também de transmitir a infecção, provavelmente através de esfoliação de células epidérmicas escamadas.

Por via aérea a inalação, ingestão ou inoculação direta. Por aerossóis; ar ambiente contaminado; contato direto; objetos recém-contaminados por secreções eliminadas pelas vias aéreas superiores (gotículas liberadas pela tosse, escarro ou espirro).

A APECIH (1999, p. 5 ) cita sobre os modos de transmissão de microrganismos, como : “Os microrganismos podem ser transmitidos tanto diretamente, por contato, por via aérea e pela exposição a sangue e líquidos corpóreos, como indiretamente, através de um vetor ou veículo inanimado”.

Neste trabalho os profissionais de enfermagem entrevistados apresentaram respostas conhecidas na Tabela 6 para cada categoria mencionada, relacionada ao modo de transmissão da doença, a freqüência deveria ser de 42 (100\%) respostas mas os resultados desta investigação mostraram uma freqüência de 35 (33,3\%) respostas para transmissão por meio de contato direto, 31 (29,5\%) por contato indireto, 14 (13,3\%), por via aérea, 10 (9,5\%), por gotículas infectantes, 8 (7,6\%), por visitantes, 04 (3,8\%), através de veículo comum contaminado, 03 (2,9\%) por técnica inadequada.

Tabela 6 - Distribuição das respostas atribuídas pelos profissionais de enfermagem, relacionadas aos tipos de transmissão das BMR na unidade de Clínica Médica d Hospital Geral de Passos - MG, 2003

\begin{tabular}{|c|c|c|}
\hline Tipos de transmissão das BMR & Freq. & $(\%)$ \\
\hline contato direto & 35 & 33,3 \\
\hline contato indireto & 31 & 29,5 \\
\hline via aérea & 14 & 13,3 \\
\hline gotículas infectantes & 10 & 9,5 \\
\hline Visitantes & 8 & 7,6 \\
\hline através de veículo comum contaminado (alimentos, água....) & 4 & 3,8 \\
\hline técnica inadequada & 3 & 2,9 \\
\hline Total & 105 & 100 \\
\hline
\end{tabular}


Os números demonstram que a maioria mencionou o contato direto e indireto, e que mais da metade dos profissionais não se referiu à via aérea, às gotículas infectantes, aos visitantes, ao veículo comum contaminado e às técnicas inadequadas. O desconhecimento ou o esquecimento de mencionar outras fontes de transmissão causa inquietação, apontando o grande risco que correm tanto os pacientes como os profissionais de saúde em relação às exposições a estes fatores.

\subsubsection{Principais reservatórios das bactérias multirresistentes}

Os principais reservatórios das BMR são os pacientes infectados/colonizados, os profissionais de saúde com colonização persistente, as superfícies ambientais contaminadas, o ambiente e o material contaminado (Starling; Silva, 1999a). Porém, conforme a Tabela 7, $30(28,8 \%)$ dos profissionais de saúde entrevistados citaram o ambiente como principal reservatório de BMR; 24 (23,1\%), o paciente colonizado/ infectado e 18 (17,3\%), menos da metade dos profissionais, citaram secreções, sangue e excreções. Esta categoria poderia estar associada ao ambiente ou ao paciente, contudo não pudemos identificar este, uma vez que 15 $(14,4 \%)$ citaram os equipamentos/ materiais contaminados; $11(10,6 \%)$, os profissionais de saúde; 3 (2,9\%), os visitantes e 3 (2,9\%), os alimentos.

Tabela 7 - Distribuição das respostas atribuídas pelos profissionais de enfermagem, relacionadas aos principais reservatórios das BMR na Unidade de Clínica Médica do Hospital Geral de Passos - MG, 2003

\begin{tabular}{lcc}
\hline \multicolumn{1}{c}{ Principais reservatórios das BMR } & Freq. & (\%) \\
\hline ambiente hospitalar ( superfícies ) & 30 & 28,8 \\
paciente colonizado / infectado & 24 & 23,1 \\
secreções, excreções e sangue & 18 & 17,3 \\
equipamentos/materiais contaminados & 15 & 14,4 \\
profissional de saúde & 11 & 10,6 \\
visitantes & 3 & 2,9 \\
alimentos & 3 & 2,9 \\
\hline Total & 104 & 100 \\
\hline
\end{tabular}


A falta de conhecimento sobre os possíveis reservatórios das BMR implicam na exposição do profissional a tais fatores sem as devidas precauções e, consequentemente, a riscos de contaminação e de disseminação destas BMR.

Araújo; Oliveira e Santos Filho (2000) determinaram o nível de contaminação de estetoscópios analisados aleatoriamente em algumas clínicas do hospital, a partir de uma situação não-epidêmica, estudando um total de 98 estetoscópios utilizados em quatro hospitais de diferentes características, da cidade de João Pessoa / PB. Obtiveram como resultado o isolamento de 96 amostras bacterianas, sendo 19/96 (19,8\%) staphylococcus aureus; 72/96 (75,0\%) staphylococcus epidermidis e 05/96 (5,2\%) de outras espécies, havendo em alguns casos a associação das duas bactérias em uma única amostra coletada. No entanto, o achado mais interessante, foi que, entre as amostras de staphylococcus aureus isoladas, foi a determinação de 05/19 (26,3\%) de linhagens resistentes à meticilina (MRSA), fato que caracteriza o potencial de ocorrência de infecção cruzada e disseminação de amostras multirresistentes no ambiente hospitalar.

\subsubsection{Profissionais que orientam sobre as precauções a serem observadas no cuidado aos portadores de BMR}

Consideramos portanto imprescindível as orientações quanto às precauções necessárias que devem ser empregadas aos portadores de BMR. Nesse hospital em estudo elas foram realizadas, principalmente, pelos enfermeiros do setor, que obtiveram uma freqüência de 30 (71,4\%) orientações, seguidos da enfermeira do CCIH com 25 (59,5\%) e, em menor proporção estas orientações também foram realizadas, pelos supervisores 12 (28,6\%); médico do paciente, oito (19\%); médico da CCIH, cinco $(11,9 \%)$ e um $(2,4 \%)$ de outros profissionais não contemplados no formulário. 
Estes resultados demonstram que a proximidade do profissional de enfermagem com o enfermeiro(a) do setor e a enfermeira da CCIH é maior do que a existente entre os demais profissionais, talvez por haver uma maior comunicação entre estas categorias.

Os entrevistados, na sua totalidade, demonstraram desconhecimento a respeito da freqüência de BMR no hospital, e quanto à freqüência deste em sua unidade de trabalho, 13 (31\%) responderam que ocorreu aproximadamente um caso de portador de BMR ao mês; 09 (21,4\%) mencionaram um caso semanal e 07 (16,7\%), um caso a cada trimestre; também para 07 (16,7\%) referiram um caso a cada 15 dias; 02 (4,8\%) não sabiam precisamente; 02 (4,8\%) achavam que eles não eram muito freqüentes; 01 (2,4\%) informou um caso ao dia e 01 (2,4\%) citou um caso a cada 04 meses. Estas respostas, por si só, demonstraram o desconhecimento dos profissionais a respeito da situação dos pacientes, pois foram contraditórias e diferentes.

A situação real do setor, nesse período (ano 2003), foi de 07 casos ao ano, portanto 0,5 casos/mês, o que caracteriza 01 caso a cada 02 meses, aproximadamente. Portanto, todas as respostas obtidas estavam incorretas, o que nos leva a deduzir que esta informação não é fornecida aos profissionais, rotineiramente. Essa situação deve ser corrigida, uma vez que a percepção de susceptibilidade da doença está diretamente relacionada ao conhecimento da situação de risco apresentada.

\subsection{Dimensões do Modelo de Crenças}

\subsubsection{Percepção de susceptibilidade da doença pelo funcionário.}

\subsubsection{Medo de contrair a doença}

Quando argüimos os profissionais de enfermagem quanto ao medo de contraírem uma bactéria multirresistente, 40 (95,2\%) responderam afirmativamente a esta questão e apenas 02 (4,8\%) negaram medo de contraírem BMR e o motivo atribuído a esse medo não foi 
explicitado por $23(56,1 \%)$ participantes. A esse respeito, devemos salientar que, no momento da resposta, os entrevistados mostraram-se pensativos, silenciosos, por alguns instantes, com expressão preocupada, e um deles relatou:

“...não sei..., prefiro não falar sobre isso”(P7),

um outro expressou-se de forma semelhante; depois de um pesado silêncio falou:

“...ora, porque tenho medo? porque pega...Porque não tem tratamento (p34)”.

P7 mencionou:

“não quero nem pensar numa coisa dessa. Deus me livre!...”.

Os demais, tiveram atitudes parecidas e alegaram desconhecer o porquê do medo de contraírem a doença. Tivemos a impressão que esta pergunta causou desconforto e repulsa entre eles. Os que responderam, em sua maioria, disseram que o motivo estava relacionado ao fato de os pacientes já estarem internados há algum tempo, e que haviam mantido contato direto com eles anteriormente sem qualquer paramentação e, de uma hora para outra foram informados da contaminação do paciente por BMR, sendo este “isolado", passando-se a implementar, a partir daquele momento, medidas preventivas para tais microrganismos. Devido a este fato, duvidavam se o isolamento resolveria mesmo o problema e questionavam sua eficiência em decorrência da situação. Uma expressão freqüentemente utilizada por eles:

”... depois de abraçar e beijar o paciente vocês vem avisando que é isolamento?”

O paciente já se interna colonizado por sua microbiota domiciliar e, na maioria das vezes, com bactérias sensíveis aos antibióticos, porém, após um período de internação começa a ser colonizado pela microbiota do ambiente hospitalar, que é resistente a diversos antibióticos ou até mesmo a todos eles. Com raras exceções, podemos fazer um diagnóstico de BMR na internação do paciente e muitas vezes, é a sua permanência prolongada no hospital que o torna um portador de BMR, seja pelo contato direto ou indireto com os profissionais, com equipamentos, materiais contaminados, ou também pela colonização e/ou 
contaminação dos procedimentos invasivos. Assim, no momento da suspeita de infecção, procede-se à cultura específica do sítio de infecção, e em caso de resultado positivo para BMR, isola-se o portador. Então, somente com o conhecimento do mecanismo de resistência será possível uma maior compreensão dos profissionais e portanto maior motivação para adesão às medidas preventivas para os cuidados aos portadores de BMR. A resposta que categorizamos, devido a este motivo explicado, foi: exposição anterior ao diagnóstico, à qual sete $(17,1 \%)$ dos trabalhadores se referiram como diagnóstico tardio.

Outros medos citados pelos profissionais entrevistados foram: medo de transmitir a doença à família quatro (9,8\%); falhas técnicas no uso do EPI três (7,3\%); comprometimento da vida profissional dois (4,9\%); inexistência de tratamento para a doença um (2,4\%); manipulação freqüente do paciente, citado por um (2,4\%) profissional (Tabela 8).

Tabela 8 - Distribuição das respostas atribuídas pelos profissionais de enfermagem, relacionadas ao medo de contraírem BMR na unidade de Clínica Médica do Hospital Geral de Passos - MG, 2003

\begin{tabular}{lccc}
\hline \multicolumn{1}{c}{ Medo de contraírem BMR } & Freq. & (\%) \\
\hline não respondeu & 24 & 56,1 \\
exposição anterior ao diagnóstico (tardio) - Contato desprotegido & 7 & 17,1 \\
transmitir para a família & 4 & 9,8 \\
falhas técnicas no uso dos EPI & 3 & 7,3 \\
comprometimento da vida pessoal - Desvalorização profissional & 2 & 4,9 \\
a doença não ter tratamento & 1 & 2,4 \\
manipulação freqüente & 1 & 2,4 \\
\hline Total & 42 & 100 \\
\hline
\end{tabular}

Os mecanismos para evitarmos a disseminação e a colonização e/ou infecção dos profissionais de saúde estão diretamente relacionados à adesão às precauções-padrão, que devem ser aplicadas a todos os indivíduos, independentemente de seu estado infeccioso, por 
isso são denominadas condutas-padrão, e quando são cumpridas integralmente, tanto o profissional como os demais pacientes estarão protegidos contra a infecção hospitalar.

As precauções-padrão baseiam-se no princípio de que o profissional não tendo idéia da presença e/ou da concentração de microrganismos nos diversos fluidos corporais dos pacientes, deve considerar todos como potencialmente infectados. Além disso, a instituição deve estabelecer políticas de controle e registro da resistência e do uso dos antimicrobianos, adotar e avaliar manuais, assim como a efetividade das normas colocadas em prática. Porém, em se tratando da temática isolamento, além das precauções-padrão, a instituição deve estabelecer protocolos requerendo alguns cuidados específicos direcionados aos profissionais de saúde que tenham lesões exsudativas ou dermatite, os quais devem ser avaliados quanto à possibilidade de continuarem em suas funções desde que utilizem paramentação adequada ou serem afastados da assistência direta ao paciente e do manuseio de instrumentais e equipamentos até seu completo restabelecimento. A instituição deve, ainda, investigar os pacientes com risco aumentado de colonização, em nível hospitalar, para estabelecer uma rotina de abordagem a pacientes transferidos de outras instituições ou entre as unidades do mesmo hospital, quando estes apresentarem fatores de risco para colonização/infecção. Os profissionais deverão, também anotar as informações relacionadas à sua situação epidemiológica (colonização/infecção) do paciente no prontuário médico, registrando-as em todo o sistema de informação do hospital, bem como nos documentos de alta ou transferência. Pacientes previamente colonizados/infectados, quando readmitidos precisam ser internados em isolamento imediatamente, onde devem permanecer até que culturas apresentem resultados negativos (Starling; Silva, 1998a). Todas estas medidas auxiliam na identificação precoce do patógeno e consequentemente, na adoção de medidas preventivas o mais rápido possível. 


\subsubsection{Medidas de prevenção da doença}

Com referência às medidas preventivas para que os profissionais não contraíssem as BMR, conforme Tabela 9, encontramos 40 (48,8\%) profissionais que utilizaram os EPI como a medida preventiva de escolha, 29 (35,4\%) empregaram a técnica da lavagem das mãos, a segunda medida mais citada para o controle de infecção, nas respostas obtidas dos profissionais entrevistados. Apesar de apresentar um índice importante, ela deveria ter sido mais representativa aproximando-se o máximo de $100 \%$ ou atingindo até mesmo $100 \%$ das respostas citadas, pois lavar as mãos é uma medida básica essencial, sendo considerada a mais importante para o controle de infecção hospitalar, por isso não deveria ter sido esquecida por nenhum profissional. Somente três $(3,7 \%)$ dos profissionais fizeram referência à higienização das mãos com solução alcoólica, questão extremamente relevante no controle de infecções. O profissional deveria ter mencionado a higienização com maior freqüência, pois podemos estar com as mãos perfeitamente higienizadas sem precisar lavá-las. Recomenda-se hoje, que o profissional lave bem as mãos quando chegar ao seu local de trabalho, higienizando-as muitas vezes durante o dia com álcool-gel ou glicerinado. Evidentemente que, na existência de uma contaminação macroscópica, devemos lavar as mãos, mas na maioria dos outros procedimentos, desde que não haja contato com matéria orgânica, basta o uso do álcool (MACHADO, 2003).

Assim, fica visivelmente clara a não-utlização da solução alcoólica pela maioria dos profissionais de saúde do Hospital Geral de Passos - MG, nas circunstâncias descritas, pois não a referiram como medidas para prevenção da contaminação/colonização por BMR. Outras medidas preventivas citadas foram: dois $(2,4 \%)$ profissionais mencionaram o cuidado com o material contaminado; um (1,2\%), acompanhamento médico periódico; um (1,2\%), seguir as orientações do Protocolo; um (1,2\%), separar material individual do paciente; um $(1,2 \%)$, 
higiene pessoal. Todas estas medidas referidas são adequadas, com exceção de um $(1,2 \%)$ profissional que indicou, como medida preventiva, evitar contato com o paciente, o que nos surpreendeu, demonstrando um comportamento extremamente preconceituoso e discriminativo.

Tabela 9 - Distribuição das respostas atribuídas pelos profissionais de enfermagem, relacionadas como medidas essenciais para prevenção da infecção por BMR na Unidade de Clínica Médica do Hospital Geral de Passos - MG, 2003

\begin{tabular}{lcc}
\hline \multicolumn{1}{c}{ Medidas para prevenção da infecção por BMR } & Freq. & (\%) \\
\hline EPI & 40 & 48,8 \\
lavar as mãos & 29 & 35,4 \\
higienização das mãos - álcool gel & 3 & 3,7 \\
cuidado com o manuseio de material contaminado & 2 & 2,4 \\
evitar contato com o paciente & 1 & 1,2 \\
acompanhamento periódico e anual & 1 & 1,2 \\
seguir as orientações do Protocolo & 1 & 1,2 \\
material individual do paciente separado & 1 & 1,2 \\
higiene pessoal & 1 & 1,2 \\
\hline Total & 79 & 100 \\
\hline
\end{tabular}

\subsubsection{Atitudes do paciente frente à doença e a necessidade de isolamento}

Interrogados sobre a atitude do paciente no momento que ele é informado sobre o seu diagnóstico, como portador de bactéria multirresistente, os profissionais de saúde descreveram as reações mais diversas dos pacientes, que foram do silêncio completo até a revolta, atitudes de enfrentamento e agressão verbal ao profissional de saúde.

Os entrevistados descreveram, conforme Tabela 10, que 30 (28,8\%) dos pacientes quando informados sobre seu diagnóstico e a necessidade de isolamento, apresentaram atitudes depressivas e que 12 (11,5\%) deles mostraram medo freqüentemente da morte, da doença e também do desconhecido. Pacientes com atitudes de revolta foram considerados de 
grande significância por 12 (11,5\%) dos entrevistados, enquanto 10 (9,6\%) referiram que a pessoa se sente rejeitada/discriminada.

Tabela 10 - Distribuição das respostas atribuídas pelos profissionais de enfermagem, relacionadas às atitudes do paciente ao ser informado sobre a necessidade do isolamento na Unidade de Clínica Médica do Hospital Geral de Passos - MG, 2003

\begin{tabular}{lcc}
\hline \multicolumn{1}{c}{ Atitudes do paciente frente ao isolamento } & Freq. & $\mathbf{( \% )}$ \\
\hline Depressão & 30 & 28,8 \\
Medo & 12 & 11,5 \\
revoltado / rebelde & 12 & 11,5 \\
discriminado / rejeitado & 10 & 9,6 \\
desinformado sobre a doença ( dúvidas, precisa de informação ) & 9 & 8,7 \\
Triste/ choroso & 8 & 7,7 \\
Aceitação & 5 & 4,8 \\
preocupado / chocado & 3 & 2,9 \\
solidão & 3 & 2,9 \\
confuso / ansioso & 3 & 2,9 \\
silencioso & 2 & 1,9 \\
envergonhado & 2 & 1,9 \\
Inseguro & 2 & 1,9 \\
Desesperado & 1 & 1,0 \\
Agitado & 1 & 1,0 \\
Indiferente & 1 & 1,0 \\
\hline Total & 104 & 100 \\
\hline
\end{tabular}

Quanto à discriminação, os depoimentos foram muito fortes e vale destacar todo seu conteúdo para compreensão e apreensão do sentimento mais manifestado pelo paciente, ao profissional de saúde:

"O paciente nos questiona até se estamos com nojo dele, (devido ao uso da paramentação).” $P 5$

“Às vezes, se tratando de um paciente consciente, lúcido, ao entrar pela $1^{a}$ vez no isolamento a impressão que se tem, ou até mesmo ele expressa verbalmente é que os meus cuidados demonstram desprezo para com ele, devido ao uso de EPI" ou então "o cliente fica deprimido e se cala.” P16 
Alguns profissionais relataram dificuldades para prestar assistência àqueles com atitudes de revolta, principalmente porque muitos pacientes se fecharam ao diálogo. Num relato, o profissional disse que um indivíduo recusou-se a ir para o isolamento, informando preferir a morte que ficar em um quarto isolado (P6). Nessas circunstâncias, o médico após ser informado solicitou o atendimento psicológico para auxiliar o paciente a enfrentar esse episódio. Nessas situações, o hospital autoriza a presença do acompanhante, que o deixa mais tranqüilo e menos ansioso.

Segundo relatos, nove $(8,7 \%)$ dos pacientes portadores de BMR demonstraram interesse em receber orientações e esclarecimentos sobre a doença, visto que o assunto não é divulgado amplamente na comunidade leiga e, portanto, eles o desconhecem. Como essa situação gera angústia, este provavelmente seja o maior motivo que desencadeie as reações negativas, como veremos a seguir:

“No primeiro instante ele fica com muito medo, dizendo que vai morrer, que está com uma doença incurável. Mas depois que ele recebe as orientações, o porquê do isolamento, ele fica mais tranqüilo, e isso ajuda muito no tratamento”(P40).

Segundo relatos, oito $(7,78 \%)$ dos pacientes demonstraram grande tristeza e/ou mostraram-se chorosos, um dos profissionais narrou o seguinte:

“Deprimido, chora ao receber a notícia, ele acha que já vai morrer logo, não tem aceitação em ficar sozinho em um quarto(P36).”

Dentre as manifestações dos pacientes, cinco (4,8\%) mostraram-se mais resignados, com atitudes de aceitação, conforme relataram os profissionais; três (2,9\%) demonstraram preocupação; três (2,9\%) relataram solidão; três (2,9\%) sentiam-se confusos / ansiosos; três (2,9\%) ficavam silenciosos; dois (1,9\%) diziam estar envergonhados; dois (1,9\%) inseguros; dois (1,9\%), desesperados; um (1,0\%)agitado; um (1,0\%) indiferente. 
Estes achados apresentam grandes semelhanças aos resultados obtidos por Moriya et al (1995), pois estando as autoras envolvidas com atividades de ensino, pesquisa e serviço de extensão à comunidade, notaram a persistência de preconceitos e estigmas sobre doenças transmissíveis (DT \} e isolamento, inclusive entre profissionais da área de saúde. Diante disso, propuseram-se a realizar um estudo sendo que um dos objetivos foi detectar entre os alunos de graduação, a percepção dos mesmos acerca das DT e isolamento. Moriya et al. (1995) pesquisaram 75 alunos, os quais descreveram os seguintes conceitos em relação ao portador de DT: um número significativo de estudantes 64\% percebeu o portador de DT como aquele com maior risco para transmissão da doença, requerendo cuidados específicos em isolamento, que envolvessem ações não só “instrumentais” como também expressivas (afetivoemocionais). Esse conceito parece demonstrar desconhecimento de que nem todas as DT são contagiosas e, portanto, o isolamento não deve ser uma regra geral. Também conceitos estereotipados, vinculados à marginalização, ficaram evidentes quando $10,7 \%$ dos entrevistados referiram-se ao portador como pessoa que deve ser isolada do convívio social. Outras percepções 5,3\% estavam relacionadas a maus hábitos alimentares e higiênicos e à analfabetização; 4\% não emitiram conceito e, finalmente, 16\% dos alunos observaram que o portador de DT era uma pessoa triste, preocupada, nervosa, carente, envergonhada, apática, desconfiada, solitária, limitada, angustiada, revoltada, marginalizada, repelida, agredida física e espiritualmente; ou seja tiveram a mesma percepção que os profissionais de saúde do Hospital Geral de Passos - MG, a respeito dos portadores de BMR isolados.

Analisando este comparativo, constatamos que os dados do estudo analisado assemelham-se aos desta pesquisa, ou seja, há conotações negativas que nos fazem lembrar as descrições de isolamento apresentadas em livros de literatura ou em filmes históricos, retratando os locais onde eram mantidas as pessoas indesejáveis a sociedade, isoladas, porque 
colocavam em risco a vida de outras pessoas. Nesse sentido, Moriya et al (1995, p. 294) sugeriram que os alunos de enfermagem:

[...]devem ser preparados para desempenharem atividades de natureza instrumental e expressiva e com capacidade crítica de modo a contribuir com ações afetivas, junto aos portadores de DT . Tornam-se clara a necessidade de se oferecer ao futuro profissional oportunidades para que possam expressar seus sentimentos e emoções no sentido de trabalhar os conceitos em suas diversas conotações, com vistas a mudanças de atitude. Faz-se necessário atuar junto ao aluno para que conceitos e conotações depreciativas sejam substituídos por outros menos carregados de estereótipos e preconceitos.

O mesmo sugerimos aos profissionais de saúde lotados nas unidades que cuidam de pacientes isolados, no atual contexto e, aos profissionais de saúde que atuam na clínica médica do Hospital Geral de Passos - MG, pela semelhança dos discursos. Isto demonstra que a situação atual encontrada não se modificou significativamente como deveria, após as diversas mudanças propostas pelos CDC (1997), no tocante às precauções.

O Ministério da Saúde recomenda que não se construam unidades específicas de isolamento, devendo a instituição destinar, a cada 40 leitos, um quarto aos portadores de DT, em todas as enfermarias (Brasil, 1985), pois, na verdade, mesmo assim o paciente sente-se discriminado diante dos demais que não se encontram em isolamento, significando que a reprodução do “isolamento” persiste mesmo ele não estando em uma unidade específica. Segundo relato dos profissionais, é desagradável quando os visitantes, acompanhantes de outros pacientes e até mesmo de pacientes vizinhos, procuram saber o diagnóstico do paciente isolado. Então, percebemos que esse problema ainda não se encontra bem resolvido e, para que isso ocorra, é necessário o desenvolvimento de estudos que busquem melhorar essa situação, não só oferecendo ao paciente acompanhamento psicológico, como também esclarecimentos freqüentes. Para mudar esse quadro, é preciso que os meios de comunicação esclareçam a comunidade em geral, a respeito, para que ela não reproduza as mesmas atitudes de épocas remotas e não discrimine os pacientes portadores de BMR ou de qualquer outra moléstia infecto-contagiosa que requer procedimento específico. 


\subsubsection{Percepção da Severidade da doença pelos profissionais de enfermagem}

Quanto à gravidade das doenças causadas por BMR, 33 (78,6\%) profissionais de saúde entrevistados disseram que elas são de difícil tratamento, enquanto outros 30 (71,4\%) consideraram-nas associadas a um maior índice de mortalidade. Tais afirmações são corretas, como mencionamos diversas vezes neste estudo, comprovadamente, elas são de difícil tratamento e estão associadas a maior índice de mortalidade podendo, inclusive, não haver tratamento para ela.

A resistência ao antibiótico iniciou-se na metade do século XX, logo após a introdução da penicilina no mercado, quando os cientistas começaram a notar o aparecimento de uma cepa penicilina-resistente de Stapphylococcus aureus. Do mesmo modo, cepas resistentes de gonococo, Shigella flexnery (uma das principais causas de morte prematura em países em desenvolvimento) e Salmonella assemelharam-se rapidamente aos Staphylococcus.

[...] problema da resistência antimicrobiana tem sido uma grande preocupação para a saúde pública, com sérias implicações econômicas, sociais e políticas que afetam nossa espécie em âmbito global, cruzando todos limites ambientais e étnicos. As cepas de micobactéria tuberculose multi droga resistente (MDR-TB) já não é limitada a qualquer país ou para pacientes co-infectados com HIV, mas surgiu em localidades tão diversas quanto a Europa Oriental, África e Ásia, entre trabalhadores de saúde e na população geral. Pneumococo penicilino-resistente está se disseminando com igual rapidez, enquanto a malária resistente está em alta e afeta milhares de crianças e adultos a cada ano. Em 1990, quase todo vibrião do cólera isolado ao redor de Nova Deli (Índia) era sensível a medicamentos baratos como furazolidona, ampicilina, co-trimoxazol e ácido nalidíxico. Agora, 10 anos depois, drogas anteriormente efetivas são altamente inúteis na batalha para conter epidemias dessa doença.

Em algumas áreas do mundo, notavelmente no sudeste asiático, 98\% de todos os casos de gonorréia são multirresistentes, o que contribui para a transmissão sexual de HIV. Na Índia, $60 \%$ de todos os casos de leishmaniose visceral não responde às drogas de primeira escolha, enquanto que no mundo industrializado, cerca de $60 \%$ das infecções hospitalares é causada por micróbios multirresistentes. Destas infecções, mais recentemente o Enterocooccus vancomicina-resistente (VRE) e o Staphylococcus aureus meticilino-resistente (MRSA), não são mais limitados às enfermarias, mas já se disseminam pela comunidade.

Embora a maioria das drogas ainda seja ativa, a sombra da resistência microbiana pode antingi-las em pouco tempo. No caso da tuberculose o aparecimento da bactéria multirresistente significa que medicamentos 
relativamente baratos devem ser substituídos por drogas até cem vezes mais caras. Outras doenças estão ficando progressivamente mais difíceis de serem tratadas por medicamentos considerados até então efetivos, devido ao seu emprego indiscriminado ou relacionado ao mau uso por pacientes que não completam o tratamento prescrito. (OMS, 2000, p. 9-10)

Dos profissionais de saúde entrevistados, 17 (40,5\%) consideraram que o tratamento pode até mesmo não existir, o que também é verdadeiro, conforme documento da OMS, que refere que as infecções hospitalares são as mais potentes para destruição e uma ameaça às intervenções médicas.

Nos Estados Unidos, aproximadamente 14.000 indivíduos são infectados e morrem a cada ano em conseqüência de micróbios multirresistentes adquiridos no hospital, tendo essas infecções multirresistentes implodido uma das principais crises do sistema de saúde do país. Particularmente nos Estados Unidos, boa parte das infecções estafilocócicas e por enterococo são crescentemente intratáveis (OMS,2000).

O surgimento de cepas de Mycobacterium tuberculosis resistentes aos quimioterápicos disponíveis é mais um desafio para o controle da tuberculose. Rabahi et al. (2003) avaliaram as características dos pacientes com tuberculose multirresistente (TBMR) e a resposta ao tratamento preconizado, no período de março de 1998 a maio de 2003, numa amostra de 15 pacientes tratados no Hospital de Doenças Tropicais Anuar Auad SES, em Goiânia-GO. Os resultados mostraram que 02 pacientes ainda se encontravam em tratamento, com evolução favorável; 05 evoluíram com cura clínica e bacteriológica; 01 abandono; 02 óbitos durante o tratamento, com baciloscopias positivas; 03 apresentaram falência e 02 foram transferidos. Diante destes resultados, concluiu que o alto índice de lesão pulmonar bilateral e pneumectomia funcional denotam que o retardo na identificação das cepas multirresistentes pode comprometer a possibilidade de tratamento curativo e que, dentre os pacientes que completaram o tratamento, 53,8\% apresentaram boa resposta, com cura ou evolução favorável. 
Para Souza Filho (2003), os avanços da medicina possibilitaram uma maior sobrevida dos pacientes, contudo estes chegam aos hospitais com idade cada vez mais avançada e tendo se submetido freqüentemente a procedimentos invasivos. O avanço da medicina também aumentou a expectativa de vida de pacientes portadores de inúmeras doenças antes incuráveis ou de sobrevida limitada, como doentes oncológicos, diabéticos, cirróticos, renais crônicos, pneumopatas e cardiopatas, dentre outros; alguns destes, candidatos inclusive a transplantes de órgãos. Toda esta situação predispõe a um atendimento de alta complexidade nas UTI, aumentando com isso as infecções hospitalares, e estas quando associadas à resistência bacteriana, aumentam a morbimortalidade, o tempo de internação e os custos do tratamento.

De acordo com a Laudman (2002), os pseudomonas e o acinetobacter multirresistentes assolaram hospitais de Nova York, tendo os bacilos Gram (-) não fermentadores multirresistentes sido um dos mais importantes problemas para os 15 hospitais do bairro do Brooklin, dessa mega cidade. Mais da metade das 419 cepas de Acinetobacter baumannii isoladas eram resistentes aos carbapenens, sendo $12 \%$ aos principais antibióticos utilizados e cinco destes casos não se mostraram susceptíveis até mesmo à polimixina (última droga de escolha). Pseudomonas aeruginosa também resistente aos carbapenens foram isoladas nestes 15 hospitais, encontrando-se 06 cepas resistentes a todos os antibióticos testados.

Também Hsueh et al. (2002) relataram aumento no isolamento de cepas de A. baumannii resistentes a todos os antibióticos testados no Hospital Universitário de Taiwan.

Zaidi; Martín e Rosado (1999), estudando as principais características epidemiológicas, clínicas e microbiológicas de uma epidemia de pneumonia associada à ventilação mecânica em uma UTI de Mérida, em Yucatán, obtiveram como resultado uma incidência de pneumonia associada à ventilação, com $74 \%$ de freqüência. A mortalidade foi de $88 \%$, bastante alta, quando a esperada era de 19,5\%. Os autores concluiram que a elevada incidência de pneumonia e mortalidade nessa unidade pode ter sido atribuída à falta de 
medidas de controle de infecção e à elevada prevalência de germes multirresistentes, devido ao uso indiscriminado e irracional de antibióticos.

Portanto, a literatura refere que nos dias atuais já é possível não existir tratamento para algumas infecções multirresistentes. A esse respeito, cabe destacar que somente um $(2,4 \%)$ profissional mostrou-se totalmente desinformado ao afirmar que a infecção BMR é como uma qualquer.

Entretanto, medidas preventivas devem ser empregadas para diminuir a disseminação destas BMR, conforme relataram os profissionais de saúde entrevistados do Hospital Geral de Passos - MG, e citaram serem elas, as principais medidas preventivas, (Tabela 11): providenciar quarto privativo (21,6\%); separação de materiais de uso individual do paciente, como termômetros, esfigmomanômetro, copos, entre outros (19,0\%); utilização de EPI (luvas, avental, máscara cirúrgica, máscara N95) (18,3\%), conforme o tipo de isolamento recomendado (contato, respiratório ou aerossóis); lavar as mãos (10,5\%); acondicionar as roupas sujas adequadamente (saco branco leitoso identificado como isolamento) (8,5\%); orientação aos visitantes / acompanhantes (8,5\%); colocação da placa de procedimento fixada na porta do quarto (3,9\%); higiene corporal (2,0\%); manter porta fechada (2,0\%); limitar o número de profissionais para cuidar do paciente (1,3\%); cuidado no preparo e administração dos medicamentos para que não ocorra contaminação $(1,3 \%)$; e outros $(0,7 \%)$, estando entre eles: a identificação do agente etiológico; restrição de visitas; imunização; não reencapar agulhas e consultar o protocolo. 
Tabela 11 - Distribuição das respostas atribuídas pelos profissionais de enfermagem, relacionadas como medidas preventivas que devem ser empregadas para diminuir a disseminação das BMR na unidade de Clínica Médica do Hospital Geral de Passos - MG, 2003

\begin{tabular}{lcc}
\hline Medidas preventivas para redução de disseminação das BMR & Freq. & (\%) \\
\hline quarto privativo & 33 & 21,6 \\
separação de materiais de uso individual & 29 & 19,0 \\
EPI & 28 & 18,3 \\
lavar as mãos & 16 & 10,5 \\
acondicionar as roupas sujas adequadamente & 13 & 8,5 \\
orientação aos visitantes / acompanhantes & 13 & 8,5 \\
placa de procedimento & 6 & 3,9 \\
higiene corporal & 3 & 2,0 \\
porta fechada & 3 & 2,0 \\
limitar número de profissionais para cuidar do paciente & 2 & 1,3 \\
cuidado no preparo e administração medicamentos & 2 & 1,3 \\
identificação do agente etiológico & 1 & 0,7 \\
restrição de visitas & 1 & 0,7 \\
Imunização & 1 & 0,7 \\
não reencapar agulhas & 1 & 0,7 \\
consultar o protocolo & 1 & 0,7 \\
\hline Total & 153 & 100 \\
\hline
\end{tabular}

Pudemos observar que os profissionais entrevistados focalizaram as medidas preventivas específicas do isolamento adotadas em sua prática diária, talvez por fazerem parte do seu conhecimento formal e informal, porém grande ênfase foi dada à necessidade de separação do paciente (quarto privativo), (21,6\%); a separação do material individual, (19,0\%) e uso de EPI, (18,3\%). Quanto à lavagem das mãos que deveria ser uma medida básica essencial, esta foi citada somente por (10,5\%) profissionais. Alguns itens de pouca relevância foram citados, embora com menor freqüência. No que se refere à limitação do número de profissionais para cuidar do paciente, ferramenta importante nessa situação, somente por $(1,3 \%)$ profissionais a citaram. No entanto, observamos que muitas medidas de grande relevância não foram sequer citadas pelos profissionais, como referido na literatura consultada. 
Para Rodrigues et al. (1997), as medidas preventivas incluem: esclarecimento da equipe de saúde em reuniões periódicas sobre a importância, virulência, mecanismos de transmissão, colonização de pacientes e equipe por bactérias; divulgação dos resultados de controle reforçando o papel da equipe nessa conduta; lavagem das mãos; vigilância prospectiva dos resultados de cultura e antibiograma pelo SCIH e separação do paciente. A retirada do paciente de uma enfermaria comum, onde há outros pacientes, visa: aumentar a probabilidade de que a lavagem das mãos e a barreira ao contato sejam efetuadas; construir barreira ao contato (luvas, capote, máscara): e formar uma equipe de enfermagem própria para assistir esse paciente. Tais medidas são aconselháveis porque aumentam a probabilidade de se efetuar a barreira ao contato; efetuar a descolonização quando a BMR for o MRSA/MARSA, vigilância dos pacientes transferidos de outros hospitais e dos reinternados com história de colonização/infecção anterior por MRSA/MARSA. Também a procura de MRSA em secreção nasal e de ferida, dentro das 24hs de internação desses pacientes, principalmente em hospital onde o MRSA/MARSA não é endêmico, vigilância de paciente de alto-risco de colonização e pesquisa de elementos da equipe de saúde são recomendadas em situações de surto e uso racional de antibióticos (RODRIGUES et al, 1997).

Os CDC (2002a) publicaram 04 estratégias e 12 etapas para impedir a resistência antimicrobiana em adultos hospitalizados; sendo elas:

A) Impedir a infecção - Prevenção da Infecção;

Etapa 1: Vacinação (Começar aplicando a vacina do Influenzae e a pneumocócica nos pacientes de risco);

Etapa 2: Retirar os cateteres o mais breve possível (usar somente o essencial, com os protocolos apropriados de inserção e cuidado do cateter); 
B) Diagnosticar e tratar a infecção eficazmente;

Etapa 3: Identificar o patógeno (realizar culturas e otimizar a dosagem e a duração do tratamento);

Etapa 4: Consultar os especialistas (os infectologistas para pacientes com infecções graves);

C) Utilizar os antimicrobianos corretamente;

Etapa 5: Utilizar os antimicrobianos padronizados;

Etapa 6: Usar dados locais (conhecer o antibiograma do seu paciente e de sua população);

Etapa 7: Não tratar a contaminação da cultura (fazer anti-sepsia adequada para coletar culturas de sangue, evitar cultivar pontas de cateteres);

Etapa 8: Não tratar a colonização;

Etapa 9: Dizer não à Vancomicina (utilização não-rotineira somente com indicação);

Etapa 10: Suspender o tratamento antimicrobiano: quando a infecção estiver tratada, quando a infecção não for diagnosticada, quando a infecção for improvável;

D) Impedir a transmissão - Prevenção da infecção;

Etapa 11: Isolar o patógeno (usar Precauções Padrão para controle da infecção, fazer a contenção dos líquidos corporais infecciosos e na dúvida consultar os peritos do controle de infecção);

Etapa 12: Quebrar a corrente do contágio (não trabalhar quando estiver doente, manter suas mãos limpas e dar exemplo).

Notamos que estas instruções não foram mencionadas pelos profissionais entrevistados, bem como os esclarecimentos à equipe de saúde; a vigilância prospectiva dos resultados de cultura e antibiograma, sem o qual não se identificam os casos que requerem isolamento; a descolonização quando o agente etiológico for o MRSA, bem como a vigilância 
dos pacientes transferidos de outros hospitais, reinternados com história de colonização ou com alto risco de colonização e, principalmente, o uso racional de antimicrobianos.

\subsubsection{Influência da instituição}

A influência favorável da instituição aparece claramente quando 22 (52,4\%) profissionais, em sua maioria, relataram que as condições necessárias para viabilizar o protocolo de isolamento específico são atendidas, enquanto 20 (47,6\%) deles mencionaram que estas eram parcialmente atendidas, não tendo nenhum deles negado essas condições.

Os profissionais que as consideraram parcialmente atendidas relataram a falta esporádica de alguns materiais no setor (não no hospital), tais como: aparelho de pressão, estetoscópio e termômetro. O pessoal do período noturno reclamou a falta do capote, material que não pode ser requisitado à noite, bem como da máscara N95, que também deve ser requisitada no almoxarifado, seção que não funciona à noite. Relataram que os profissionais do turno vespertino não fazem a provisão adequada de materiais para o pessoal do noturno.

Alguns fatores de influência auxiliam para maior apreensão do conteúdo de prevenção utilizado nos Serviços de Controle de Infecção Hospitalar e, conseqüentemente, de medidas preventivas de isolamento. Dentre os fatores de influência listados e apresentados aos entrevistados para que elegessem os mais importantes, na ordem de escolha, tais profissionais indicaram os seguintes fatores: 36 assinalaram o treinamento adequado (85,7\%); 28 indicaram a necessidade dos EPI estarem disponíveis (66,7\%) e 18 que os supervisores devem fornecer as orientações necessárias (42,9\%). Consideraram de menor influência, a informação em todos os setores sobre os riscos dos patógenos transmitidos pelo sangue registrada por nove profissionais (21,4\%); treinamento especial para o uso de EPI também por nove, $(21,4 \%)$ e 
apenas um assinalou a opção de já possuírem conhecimento adequado e conscientização $(2,4 \%)$

Em relação ao conhecimento adquirido pela equipe, conforme informação dos mesmos, este foi proporcionado prioritariamente pela prática diária no hospital, 19 (39,6\%); pelo curso de formação, 15 (31,3\%) e na própria unidade de trabalho, 13 (27,1\%), que atingiu percentual significativo. Assim, se associarmos a unidade de trabalho ao conhecimento apreendido no hospital, de forma geral, encontraremos um percentual de 32 (52,5 \%) na instituição e de apenas um(2,1\%) no domicílio. Quando indagamos de que modo esse conhecimento foi levado até o profissional, as respostas foram: através da prática diária, 19 (39,6\%); na sala de aula 15 (31,3\%) ; através de treinamentos elaborados pela CCIH, 13 (27,1\%) e somente um $(2,1 \%)$ revelou ser por intermédio da literatura. Ao questionarmos qual o profissional levou até eles esse conhecimento, 19 (39,6\%) responderam que foi a enfermeira da CCIH, 14, $(29,2 \%)$ indicaram o docente do curso de formação profissional; oito $(16,7 \%)$ os enfermeiros chefes do setor; três $(6,3 \%)$, os supervisores; dois $(4,2 \%)$, os médicos, um $(2,1 \%)$ os livros e os colegas respectivamente, conforme apresentado na Tabela 12. 
Tabela 12 - Distribuição das respostas atribuídas pelos profissionais de enfermagem, relacionadas à forma, local e ao profissional que orientou sobre as BMR na unidade de Clínica Médica do Hospital Geral de Passos - MG, 2003

\begin{tabular}{llcc}
\hline & Orientações sobre BMR & Freq. & (\%) \\
\hline \multirow{4}{*}{ Local } & no hospital & 19 & 39,6 \\
& curso de graduação & 15 & 31,3 \\
& no setor & 13 & 27,1 \\
& no domicílio & 1 & 2,1 \\
& Total & 48 & 100 \\
& & & \\
& prática diária & 19 & 39,6 \\
& aula & 15 & 31,3 \\
Estratégia & treinamento CCIH & 13 & 27,1 \\
& literaturas & 1 & 2,1 \\
& Total & 48 & 100 \\
& & & \\
& & 19 & 39,6 \\
& enfermeira CCIH & 14 & 29,2 \\
Orientador & professor curso auxiliar & 8 & 16,7 \\
& enfermeiros do setor & 3 & 6,3 \\
& supervisor & 2 & 4,2 \\
& médicos & 1 & 2,1 \\
& Literatura & 1 & 2,1 \\
& colegas & 48 & 100 \\
\hline
\end{tabular}

A situação demonstra que os profissionais recebem conhecimento considerável a respeito da problemática vivenciada pelo portador da BMR introduzido pelo hospital, seja na prática diária, em treinamentos ou através de profissionais. Tais informações são assimiladas passivamente na escola, mas existe uma grande lacuna causada pela falta de interesse do profissional em buscar conhecimento através da leitura ou de outros meios de comunicação, como a internet. Também deixaram evidente a falta de divulgação desse assunto pelos meios de comunicação populares, como rádio e televisão, ficando essa abordagem restrita ao meio específico.

A placa sinalizadora colocada na porta do quarto do isolamento foi considerada por 22 (33,8\%), a maioria, como educativa e orientadora; necessária e importante, para 22 (33,8\%), 
contudo oito (12,3\%) profissionais mencionaram que ela desperta a curiosidade dos visitantes, embora tenha sido considerada protetora para quatro (6,2\%) profissionais; outros quatro (6,2\%) a consideraram restritiva; três $(4,6 \%)$, discriminadora e dois $(3,1 \%)$ não responderam, prevalecendo os benefícios da sua utilização, conforme representado na Tabela 13.

Tabela 13 - Distribuição das respostas atribuídas pelos profissionais de enfermagem, relacionadas à opinião sobre a placa de isolamento colocada na porta do quarto do paciente na unidade de Clínica Médica do Hospital Geral de Passos - MG, 2003

\begin{tabular}{lcc}
\hline \multicolumn{1}{c}{ Opinião sobre a placa de isolamento } & Freq. & (\%) \\
\hline educativa / orientadora / sinal de alerta & 22 & 33,8 \\
necessária / importante & 22 & 33,8 \\
desperta curiosidade ( visitantes ) & 8 & 12,3 \\
protetora & 4 & 6,2 \\
restritiva & 4 & 6,2 \\
discriminativa & 3 & 4,6 \\
não respondeu & 2 & 3,1 \\
\hline Total & 65 & 100 \\
\hline
\end{tabular}

A utilização dos EPI nem sempre ocorre como deveria, muitas vezes os profissionais deixam de utilizá-los, comprometendo o controle das infecções. Porém, quando consultados sobre as razões da desobediência a essas orientações, as respostas de 17 (40,5\%) se encaixaram, em maior proporção, na categoria outros, que inclui os seguintes motivos: auto confiança (acreditam que não vão contrair a doença); resistência (não usam porque não querem, por preguiça, por motivo injustificado, por falta de conscientização, por desconforto, por ignorância, porque as luvas colam no esparadrapo e devido ao diagnóstico tardio). Na hora de se justificarem, referiram que eram os colegas que não utilizavam os EPI e afirmaram que faziam uso deles sempre. Como outras razões para a desobediência, 13 (31\%) mencionaram o acesso difícil aos EPI; e 10 (23,8\%), a inconveniência do seu uso como o principal fator, nove $(21,4 \%)$ interferência no trabalho e em percentual inferior, quatro $(9,5 \%)$ disseram desconhecer a finalidade do seu uso e três $(7,1 \%)$ a inviabilidade de seu emprego. 
Foi surpreendente a constatação de que, além dos motivos mencionados, as razões para desobediência do uso dos EPI estão relacionadas à resistência do profissional, pura e simplesmente, conforme relatado:

“não usam porque não querem”(P13,14,23,34),

É bastante preocupante o desrespeito de alguns profissionais para com os demais pacientes, pois observamos que muitos se preocupam somente com a sua pessoa. Segundo relato de profissionais entrevistados, os colegas assim justificam o fato de não utilizarem a paramentação:

“Não tem perigo, não vou pegar a doença”(P24,35,37).

Para a maioria dos entrevistados 27 (64,3\%), a Semana Interna de Prevenção de Acidentes (SIPAT), promovida pela Comissão Interna de Prevenção de Acidentes (CIPA), contribui para adesão ao uso dos EPI; já 08 (19\%) acham que contribui pouco, para 01 (2,4\%) ela não contribui e 06 (14,3\%) relataram não saber, pois não participam das palestras e atividades da SIPAT. Este tem sido um bom artifício para estimular a utilizar o EPI.

As táticas de prevenção utilizadas pelo SCIH que foram consideradas as mais efetivas pelos profissionais para obter maior adesão às medidas preventivas dirigidas aos portadores de BMR, tendo estes a opção de listar 02 condições mais importantes, foram as seguintes: 31 (73,8\%) profissionais consideraram a tática da enfermeira e/ou infectologista reunir-se com os funcionários para explicar medidas preventivas de maneira informal. Dezenove $(45,2 \%)$ profissionais indicaram, também significativa, a programação de atividades para atualização da equipe de enfermagem, que ocorre de modo formal; 17 (40,5\%) deles mencionaram a elaboração de um manual de procedimento para o setor e receberam menor aceitação, indicadas por 11 (26,2\%), as táticas de confecção de informativos para conscientização do benefício que o paciente receberá se o profissional atender ao Protocolo de Isolamento 
Específico. Também foi pouco aceita, cinco (11,9\%), a tática de contar com a supervisão rigorosa e com a colaboração da enfermeira do setor.

O manual de procedimento já existe no setor, não como impresso, mas disponível na rede do computador em um programa denominado “ABC”, amplamente divulgado na instituição, porém ainda não acessado por todos. Quanto às táticas escolhidas, estas deverão ser reconsideradas para os futuros treinamentos.

\subsubsection{Influência Pessoal}

Considerando o fato de o profissional estar cuidando de um paciente com BMR, pedimos que indicasse quando lava suas mãos e as respostas encontradas, conforme Tabela 14, foram as seguintes: 17 (40,5\%) referiram que antes e após o contato com o paciente e entre os procedimentos, ou seja, ao entrar no quarto, entre os procedimentos, e ao sair do quarto; 13 (31\%) antes e após o contato com o paciente, ou seja, ao entrar e ao sair do quarto; 08 (19\%) entre os procedimentos; 02 (4,8\%) após o contato com o paciente, ou seja, ao sair do quarto; 01(2,4\%) antes do contato com o paciente, ou seja, ao entrar no quarto; e às vezes, respectivamente.

Tabela 14 - Distribuição das respostas atribuídas pelos profissionais de enfermagem, relacionadas à lavagem das mãos ao cuidar de um portador de BMR na unidade de Clínica Médica do Hospital Geral de Passos - MG, 2003

\begin{tabular}{lcc}
\hline \multicolumn{1}{c}{ Momento de lavagem das mãos ao cuidar do portador de BMR } & Freq. & (\%) \\
\hline antes e após o contato com o paciente ( ao entrar e sair do quarto ) e & 17 & 40,5 \\
entre procedimentos. & 13 & 31,0 \\
antes e após o contato com o paciente ( ao entrar e sair do quarto ) & 8 & 19,0 \\
entre os procedimentos & 2 & 4,8 \\
após o contato com o paciente ( ao sair do quarto ) & 1 & 2,4 \\
antes do contato com o paciente ( ao entrar no quarto ) & 1 & 2,4 \\
às vezes & 42 & 100 \\
\hline Total & \\
\hline
\end{tabular}


Quando interrogamos em quais situações utilizam o álcool glicerinado nas mãos, 23 (36,5\%), a maioria, responderam entre os procedimentos; 22 (34,9\%), após lavarem as mãos; $08(12,7 \%)$, na troca de pacientes; 04 (6,3\%), sempre que passavam por um dispensador; 02 (3,2\%), ao término da jornada de trabalho; 02 (3,2\%), após manusearem materiais contaminados; 02 (3,2\%), não utilizavam. Assim, verificamos que somente 23 (36,5\%) utilizavam o álcool entre os procedimentos, situação considerada mais adequada dentre as apresentadas, pois pouco mais da metade dos profissionais entrevistados procediam corretamente, conforme a recomendação da Portaria 2616 do Ministério da Saúde ou de acordo com o novo Guideline do CDC (BRASIL, 1998; CDC, 2002b), conforme representado na Tabela 15.

Tabela 15 - Distribuição das respostas atribuídas pelos profissionais de enfermagem, relacionadas à utilização do álcool glicerinado a $70 \%$ nas mãos, na unidade de Clínica Médica do Hospital Geral de Passos - MG, 2003

\begin{tabular}{lcc}
\hline \multicolumn{1}{c}{ Momento de utilização de álcool glicerinado } & Freq. & (\%) \\
\hline entre os procedimentos & 23 & 36,5 \\
após lavar as mãos & 22 & 34,9 \\
entre pacientes diferentes ( na troca de pacientes ) & 8 & 12,7 \\
sempre ao passar pelo dispensador de álcool & 4 & 6,3 \\
término da jornada de trabalho & 2 & 3,2 \\
após manusear materiais contaminados & 2 & 3,2 \\
não utilizo & 2 & 3,2 \\
\hline Total & 63 & 100 \\
\hline
\end{tabular}

A Portaria MS 2.616/98, que regulamenta as ações de controle de infecção hospitalar no país, em seu anexo IV, Programa de Controle de Infecção Hospitalar - Lavagem das mãos, traz as seguintes recomendações:

- Lavagem das mãos é a fricção manual vigorosa de toda a superfície das mãos e punhos, utilizando-se sabão/ detergente, seguida de enxágüe abundante em água corrente;

- A lavagem das mãos é, isoladamente, a ação mais importante para a prevenção e controle das infecções hospitalares; 
- O uso de luvas não dispensa a lavagem das mãos antes e após contatos que envolvam mucosas, sangue ou outros fluidos corpóreos, secreções ou excreções;

- A lavagem das mãos deve ser realizada tantas vezes quanto necessária, durante a assistência a um único paciente, sempre que envolver contato com diversos sítios corporais, entre cada uma das atividades;

- A lavagem e anti-sepsia cirúrgica das mãos é realizada sempre antes dos procedimentos cirúrgicos;

- A decisão para a lavagem das mãos com uso de anti-séptico deve considerar o tipo de contato, o grau de contaminação, as condições do paciente e o procedimento a ser realizado.

A Lavagem das mãos com anti-séptico é recomendada em;

- realização de procedimentos invasivos ;

- prestação de cuidados a pacientes críticos;

- contato direto com feridas e/ou dispositivos, tais como cateteres e drenos.

- Devem ser empregadas medidas e recursos com o objetivo de incorporar a prática da lavagem das mãos em todos os níveis de assistência hospitalar.

- A distribuição e a localização de unidades ou pias para lavagem das mãos, de forma a atender à necessidade nas diversas áreas hospitalares, além da presença dos produtos, é fundamental para a obrigatoriedade da prática (BRASIL, 1998).

Atualmente, a recomendação mais atualizada para lavagem das mãos está contida no último Guideline do CDC (2002b). O Guideline sobre a lavagem das mãos publicado pelo CDC em 1985 reforçou a importância da lavagem das mãos com água e sabão antes e depois do contato com o paciente, do uso de anti-sépticos antes e depois de procedimentos invasivos com paciente de alto risco e do uso de solução sem água (álcool), apenas na ausência de pias. Contudo, a alteração ocorrida no novo guia do CDC de 2002b, sobre a lavagem das mãos, refere-se à introdução de um novo termo genérico, a higienização das mãos, que se aplica tanto à lavagem das mãos com anti-séptico,como à fricção com anti-sépticos ou anti-sepsia cirúrgica das mãos. Outro ponto importante, citado pelos profissionais foi a ampla utilização de produto à base de álcool para higiene das mãos, inclusive sem lavar as mãos. O Guideline recomenda, no entanto, a utilização do gel alcoólico quando as mãos não estiverem visivelmente sujas, em todas aquelas oportunidades de higienização, entre elas: antes do contato direto com paciente; antes de calçar luvas estéreis para inserção de cateter venoso central; antes da inserção de cateter urinário, de cateter vascular periférico ou de outro dispositivo invasivo que não exija procedimento cirúrgico; após contato com a pele intacta do 
paciente e com fluidos corporais ou excreções, membrana mucosa, pele não-intacta ou troca de vestimenta; durante a mudança ou manipulação de um sítio contaminado para um sítio limpo, no cuidado ao paciente; após contato com objetos inanimados ao redor do paciente (CDC, 2002b).

A eficácia e a praticidade do álcool utilizado isoladamente devem aparecer nesse momento, satisfazendo as necessidades dos profissionais e do paciente. O ideal é lavar as mãos sempre que possível, eventualmente complementando esse ato com uma solução alcoólica, pois como a atividade de lavar as mãos toma tempo do profissional, muitas vezes ele deixa de fazê-la. Assim, o álcool deve estar disponível para que o utilize nas inúmeras situações recomendadas, porém não basta passá-lo nas mãos, é necessário friccioná-lo por 30 segundos para obter o efeito desejado (MACHADO, 2003).

Pittet; Mourouga e Perneger (1999), descrevendo uma abordagem feita sobre higiene das mãos na equipe multiprofissional do Hospital da Universidade de Genebra, Suíça, relataram que, nessa experiência, quanto maior a necessidade de higiene das mãos, menos elas eram efetivamente lavadas, isto é, quanto mais ocupado o profissional de saúde, menos provável se torna a lavagem das mãos. Com base no estudo, realizado ele acredita que o sucesso ao cumprimento das recomendações para lavagem das mãos pode ser atribuído a vários fatores, tais como: o emprego do álcool gel torna a higiene das mãos mais acessível, rápida e com maior espectro de atividade antimicrobiana; observações contínuas e avaliação do desempenho com feedback para a equipe; abordagem multidisciplinar com utilização de estratégias de marketing, ferramentas de educação, lembretes, e feedback para a equipe, tornando-se uma prioridade institucional. O autor referiu que a lição foi remover obstáculos, capacitar, e reforçar as práticas adequadas.

O capote foi o EPI citado pelos profissionais entrevistados como aquele que representa maior dificuldade de utilização, com 29 (69\%) referências, e o motivo mais alegado foi que 
ele esquenta muito; a máscara foi citada por 13 (31\%) profissionais, que alegaram, principalmente que ela sufocava e embaçava os óculos dos que os utilizam; quanto às luvas, foram pouco mencionadas, 03 (7,1\%), e o motivo alegado foi que grudava no esparadrapo.

Realmente, o capote de mangas compridas em um quarto sem ar condicionado e em um país de clima tropical como o nosso, mais precisamente em uma cidade com freqüente temperatura elevada, é bastante desconfortável, contudo os meios justificam o fim, ou seja, apesar do desconforto, deve-se levar em conta que está em jogo a vida de um paciente e o nosso dever é zelar por ela. Com a evolução tecnológica, a indústria que desenvolve produtos hospitalares, usando sua criatividade, podendo aperfeiçoar a confecção do capote, tornando-o mais adequado, mais leve e menos quente; aplicando-se o mesmo aos defeitos das máscaras e das luvas.

Ao assistirem o paciente portador de BMR, os profissionais relataram adotar as seguintes condutas: solicitação de quarto privativo, 42 (100\%); uso adequado de EPI, 41 (97,6\%); separação de material de uso único, 40 (95,2\%) e orientação aos visitantes, 30 $(71,4 \%)$

Quase todos os profissionais aderiram às condutas citadas, somente a orientação aos visitantes recebeu menor percentual, justificado pelo fato de o pessoal do período noturno não fazer estas orientações, pois o horário de visitas é realizado no turno matutino e vespertino.

A freqüência da lavagem das mãos, no caso de o paciente ser portador de BMR, variou entre os profissionais entrevistados, pois $28(66,7 \%)$ deles relataram realizar esta atividade com maior freqüência somente nesta situação, e outros 14 (33,3\%) informaram lavar as mãos com igual freqüência. Esta freqüência não deveria variar, pois as precauções-padrão e as orientações referentes à lavagem das mãos não se diferenciam conforme o diagnóstico do paciente, significando que o profissional deve lavar as mãos conforme as recomendações do CDC, independentemente de o paciente ser ou não portador de BMR, já que a recomendação 
é a mesma para todos os casos. Nenhum profissional relatou lavar as mãos com menor freqüência, obviamente.

Quanto ao comportamento pessoal do profissional de enfermagem, observamos que 35 (83,3\%) estavam com os uniformes limpos; 31 (73,8\%) utilizavam relógios; 14 (33,3\%) portavam aliança; dois (4,8\%) encontravam-se com as unhas grandes e nenhum fazia uso de pulseira.

Apesar do relógio dificultar a lavagem do pulso, o mesmo é considerado material de bolso para a enfermagem e, portanto, indispensável o seu uso na prática diária; portanto ele pode ser utilizado desde que se tome o cuidado de removê-lo ou afastá-lo para lavar o pulso. No caso da aliança, está associada às crenças dos pacientes e como representa seus valores culturais, alegam que não devem tirá-las; quanto aos anéis, estavam sendo utilizados por cinco (11,9\%) profissionais. Observamos que sete (16,7\%) deles vestiam uniformes sujos, evidenciando descuido com a higiene e a aparência.

Questionamos os entrevistados se o fato de outros profissionais não utilizarem a paramentação recomendada influenciava o seu comportamento ou de outros colegas, tendo, 11 (26,2\%) deles respondido afirmativamente, enquanto 31 (73,8\%) disseram que a atitude de outros profissionais não influenciava o seu comportamento. Felizmente, a maioria demonstrou amadurecimento, não se deixando influenciar pelas condutas incorretas de outros profissionais.Quando interrogados sobre quais profissionais mais freqüentemente não aderiam às orientações do Protocolo de Isolamento, mencionaram os médicos, em sua maioria.

A maioria dos profissionais entrevistados, 39 (92,9\%), referiu não possuir quaisquer alergias que os impossibilitassem de utilizar as das medidas preventivas para o cuidado de portadores de BMR, apenas três $(7,1 \%)$ deles possuíam alergias desencadeadas pelo álcool e talco das luvas. 


\subsubsection{Relação entre benefícios e barreiras}

Perguntamos aos profissionais de enfermagem se as medidas preventivas empregadas no cuidado aos portadores de BMR em isolamento promoviam benefícios para o mesmo, tendo a grande maioria, 41 (97,6\%) respondido afirmativamente. Apenas um $(2,4 \%)$ profissional não acreditava que estas medidas promovessem benefícios à sua pessoa. $\mathrm{O}$ fato de um único profissional não acreditar que estas medidas promovam benefícios para si mesmo, o caracteriza como um profissional desinformado ou descrente, ou quem sabe resistente a mudanças, o que nos preocupa, pois ele não acredita nas medidas de precaução, possivelmente não irá aderir às mesmas, podendo inclusive ser um disseminador de BMR na instituição.

Os benefícios mencionados pelos entrevistados , conforme Tabela 16, foram: a proteção, 20 (39,2\%); a prevenção de contaminação pessoal, 18 (35,3\%); e em menor proporção, cinco $(9,8 \%)$ relataram ser o benefício de não ser o disseminador da doença; dois (3,9\%) alegaram segurança profissional; outros dois (3,9\%) segurança para os seus familiares; quatro (7,8\%) não souberam especificar.

Tabela 16 - Distribuição das respostas atribuídas pelos profissionais de enfermagem, relacionadas aos benefícios que as medidas preventivas promovem aos mesmos na unidade de Clínica Médica do Hospital Geral de Passos - MG, 2003

\begin{tabular}{lcc}
\hline \multicolumn{1}{c}{ Benefícios das medidas preventivas } & Freq. & (\%) \\
\hline proteção / prevenção & 20 & 39,2 \\
prevenir contaminação ( infecção ) & 18 & 35,3 \\
evita disseminação pelo profissional & 5 & 9,8 \\
não especificou & 4 & 7,8 \\
segurança profissional & 2 & 3,9 \\
segurança para familiares & 2 & 3,9 \\
\hline Total & 51 & 100 \\
\hline
\end{tabular}


Analisando essa situação, constatamos que a preocupação principal era não adquirir a doença, ou seja, prevenir-se contra a infecção realizando a sua proteção pessoal. A maioria desses profissionais não viam a não-disseminação da bactéria no âmbito hospitalar ou no âmbito doméstico como benefício pessoal. Eles não consideravam o fato de que não estando colonizados, conseqüentemente, não colonizariam seus familiares, levando a bactéria para a comunidade. Também não pensavam que não estando colonizados não seriam os responsáveis pela disseminação ou até mesmo por um de surto no âmbito hospitalar. De acordo com Laudman (2002), as cepas de Acinetobacter baumannii isoladas em diversos hospitais do Brooklin, em Nova York, foram atribuídas à pressão seletiva devido ao uso de cefalosporinas; à internação de pacientes colonizados oriundos de outros hospitais; à rotação de médicos e estudantes de medicina entre estas instituições e as falhas no emprego das medidas de controle de infecção.

Esta situação configura a necessidade de trabalharmos com esta equipe, levando informação e realizando discussão em grupo para resolução das dúvidas e conflitos.

Ao serem interrogados se as medidas específicas de isolamento promoveriam benefícios para o cliente, a grande maioria, 41 (97,6\%), respondeu que sim, somente um $(2,4 \%)$ achava que estas medidas não promoveriam benefícios ao cliente. Quanto aos benefícios mencionados pelos profissionais, conforme Tabela 17, na ordem de importância, foram: 23 (39,0\%) disseram que evitam que o paciente adquirisse novas doenças; 13 (22,0\%) consideraram que evitavam que o paciente disseminasse a BMR para outros pacientes; 13 $(22,0 \%)$ achavam que o isolamento conferia proteção e segurança ao paciente; oito $(13,6 \%)$ acreditavam que, em função do isolamento, o paciente teria uma recuperação mais rápida. Na entrevista, explicaram que o isolamento evitaria que o paciente adquirisse outras doenças. Apenas um (1,7\%) disse que devido ao tratamento específico adequado, um $(1,7 \%)$ profissional não respondeu à questão. 
Tabela 17 - Distribuição das respostas atribuídas pelos profissionais de enfermagem, relacionadas aos benefícios que adequação às medidas preventivas promovem aos “clientes” na unidade de Clínica Médica do Hospital Geral de Passos MG, 2003

\begin{tabular}{lcc}
\hline \multicolumn{1}{c}{ Benefícios das medidas preventivas } & Freq. & (\%) \\
\hline evita adquirir infecção & 23 & 39,0 \\
evita disseminação & 13 & 22,0 \\
proteção/ segurança & 13 & 22,0 \\
recuperação mais rápida (menor permanência hospitalar ) & 8 & 13,6 \\
tratamento específico adequado & 1 & 1,7 \\
não respondeu & 1 & 1,7 \\
\hline Total & 59 & 100 \\
\hline
\end{tabular}

Observamos que quase todas as respostas estavam relacionadas à proteção do paciente, e que no isolamento eles estavam protegidos de outras doenças, porém o real motivo do isolamento, o de evitar a disseminação das BMR, foi citado apenas por 13 (22\%) profissionais. No caso da proteção, se uma instituição promove um Protocolo de Isolamento Específico, com certeza ela estará zelando pela sua clientela, protegendo-a da disseminação de BMR.

Alguns fatores exercem grande influência à adesão das medidas preventivas de Isolamento, alguns facilitam a execução destas medidas e existem os que dificultam ou até mesmo impedem os profissionais de exercê-las.

Quanto aos fatores que facilitavam o emprego destas medidas, conforme Tabela 18, quatorze $(22,2 \%)$ profissionais referiam-se à informação e profissionais bem orientados e esclarecidos sobre o assunto; treze (20,6\%) consideraram a rápida identificação do agente etiológico, pois o diagnóstico mais rápido também facilita o emprego das medidas preventivas. Consideraram esta última importante, pois sem ela sequer serão instituídas as medidas preventivas de isolamento; nove (14,3\%) mencionaram que os EPI devem estar sempre disponíveis no setor; para seis $(9,5 \%)$ deve haver um maior número de leitos disponíveis e cinco (7,9\%) citaram a necessidade do fácil acesso aos materiais e equipamentos 
e em quantidade suficiente; cinco (7,9\%) referiram-se a ambiente apropriado com ante-sala; quatro (6,3\%) não responderam; dois (3,2\%) acreditavam que a conscientização profissional facilitaria esta adesão; um (1,6\%) referiu-se a local específico para isolamento; um (1,6\%) considerava necessária uma boa orientação aos visitantes e acompanhantes; um (1,6\%) acreditava que deveria ser obrigatório o uso de EPI; um (1,6\%) citam o apoio da chefia como facilitador e um (1,6\%) outro, a placa de isolamento.

Tabela 18 - Distribuição das respostas atribuídas pelos profissionais de enfermagem, relacionadas sobre os principais fatores que facilitam o emprego das medidas preventivas ao portador de BMR na unidade de Clínica Médica do Hospital Geral de Passos - MG, 2003

\begin{tabular}{lcc}
\hline Fatores que facilitam o emprego das medidas preventivas & Freq. & (\%) \\
\hline Informação - profissionais bem orientados sobre o assunto & 14 & 22,2 \\
Rápida identificação do agente etiológico - diagnóstico precoce & 13 & 20,6 \\
EPI disponível & 9 & 14,3 \\
maior número de leitos disponíveis & 6 & 9,5 \\
materiais e equipamentos suficientes e de fácil acesso & 5 & 7,9 \\
Ambiente apropriado: quarto com ante-sala & 5 & 7,9 \\
não respondeu - inadequada & 4 & 6,3 \\
conscientização profissional & 2 & 3,2 \\
local específico para isolamento & 1 & 1,6 \\
orientação ao acompanhante - visitantes & 1 & 1,6 \\
obrigatoriedade do uso de EPI & 1 & 1,6 \\
apoio da chefia & 1 & 1,6 \\
placa de procedimento & 1 & 1,6 \\
\hline Total & 63 & 100 \\
\hline
\end{tabular}

Como fatores dificultadores ou que até mesmo impediriam o emprego das medidas preventivas de isolamento, conforme Tabela 19, na ordem de importância, 24 (26,7\%) citaram a falta de vagas em decorrência da dificuldade para internar o paciente em isolamento, pois devido ao fato de o quarto da enfermaria possuir três leitos, o paciente em isolamento vai ocupar três vagas, ficando dois leitos vagos, que só serão preenchidos se um outro paciente for internado com a mesma patologia. Um percentual muito significativo recebeu o 
“diagnóstico tardio”, com 18 (20,0\%) referências à demora para solicitação dos exames específicos, ou seja, para fazer o diagnóstico definitivo. Também $13(14,4 \%)$ citaram a falta de material no setor, o qual é reposto conforme a provisão e solicitação realizada pela enfermeira chefe do setor; $11(12,2 \%)$ solicitaram melhor orientação para os visitantes/acompanhantes que algumas vezes adentram no hospital sem serem informados de que o paciente se encontra em isolamento, refletindo a falta de comunicação entre a recepção do hospital e a enfermeira do setor. Alguns profissionais queixaram-se que, às vezes, faltava informação também a eles, principalmente ao pessoal do noturno sete (7,8\%). Os profissionais, sete $(7,8 \%)$, se queixaram que o tempo dispensado a um paciente em isolamento era maior do que o dispensado aos demais pacientes; cinco (5,6\%), da falta de EPI disponível no setor; quatro $(4,4 \%)$ da falta de um vestiário para os profissionais trocarem de roupa no final do turno, apenas um (1,1\%) referiu não ter nenhuma dificuldade.

Tabela 19 - Distribuição das respostas atribuídas pelos profissionais de enfermagem, relacionadas aos principais fatores que dificultam/impedem o emprego das medidas preventivas ao portador de na unidade de Clínica Médica do Hospital Geral de Passos - MG, 2003

\begin{tabular}{lcc}
\hline \multicolumn{1}{c}{$\begin{array}{c}\text { Fatores que dificultam/impedem o emprego das medidas } \\
\text { preventivas ao portador de BMR }\end{array}$} & Freq. & (\%) \\
\hline faltam vagas & 24 & 26,7 \\
diagnóstico tardio & 18 & 20,0 \\
falta de material disponível & 13 & 14,4 \\
melhor orientação aos visitantes / acompanhantes & 11 & 12,2 \\
falta informação ao profissional & 7 & 7,8 \\
tempo maior dispensando ao paciente para o cuidado & 7 & 7,8 \\
falta EPI & 5 & 5,6 \\
falta vestuário no setor & 4 & 4,4 \\
não tem dificuldades & 1 & 1,1 \\
\hline Total & 90 & 100 \\
\hline
\end{tabular}

Contudo, analisando os benefícios das medidas preventivas tanto para o portador de BMR, como para o profissional, em relação aos fatores facilitadores e dificultadores, 
pudemos concluir que os profissionais acreditavam e conheciam os benefícios gerados por estas medidas, porém algumas falhas técnicas deveriam ser corrigidas, como revisão da grade de materiais (termômetros, esfigmomanômetro...) do setor e adequação das solicitações de material de uso diário (EPI). Quanto à área física, disponibilizar mais quartos para isolamento, visto que a demanda era grande e faltavam vagas, concluindo, um treinamento torna-se fundamental para a prática diária. Atualmente tem-se desenvolvido a compreensão da importância dos aspectos comportamentais, cognitivos, emocionais e sociais relacionados a ao aumento e/ou redução da adesão dos profissionais da saúde a medidas como as de precauçõespadrão (NEVES NETO, 2003).

Nesse sentido, os treinamentos serão mais eficientes se conhecermos os sistemas de crença pessoal e/ou grupal acerca da percepção da exposição do profissional de saúde ao risco, pois quando esta é subjetiva e muito baixa, qualquer programa de educação é avaliado como subjetivo pelo profissional. E, neste estudo nos propusemos a isto, ou seja, a conhecer os sistemas de crenças dos profissionais de saúde da instituição onde desenvolvemos a pesquisa, pois acreditamos que este seja o primeiro passo rumo ao planejamento para aumentar a adesão destes profissionais às medidas preventivas para o cuidado dos portadores de BMR.

A equipe de profissionais de saúde que estudamos pertence a três categorias profissionais distintas: enfermeiros, técnicos e auxiliares de enfermagem. Composta predominantemente por auxiliares de enfermagem do sexo feminino, com o tempo de serviço variável, nela predomina o tempo entre um e seis anos e a idade entre 20 a 35 anos, estando os trabalhadores distribuídos nos diversos turnos de trabalho, na clínica médica feminina e na masculina . Em resposta às entrevistas realizadas, os profissionais demonstraram ter um conhecimento restrito e limitado sobre a temática bactérias multirresistentes, contudo, quase a sua totalidade estava ciente dos riscos que o portador de BMR oferecia à equipe de saúde. 
Apesar de não saberem exatamente onde se encontravam topograficamente localizadas as BMR, e de terem um conhecimento restrito sobre as espécies identificadas na instituição que trabalhavam, os profissionais conseguiam identificar os grupos que apresentavam maior risco, identificação realizada somente por uma minoria. Os profissionais de enfermagem recebiam orientações sobre as precauções necessárias no cuidado ao portador de BMR, predominantemente de enfermeiros do setor e da enfermeira da CCIH porém constatamos que, rotineiramente, não recebiam informação sobre a freqüência de BMR no hospital. Verificamos também, que os profissionais possuíam um conhecimento incorreto sobre a freqüência da ocorrência de cepas multirresistentes na sua unidade de trabalho, pois freqüentemente associavam o isolamento por qualquer moléstia infecto-contagiosa à infecção por BMR. Também não conseguiam dissociar os tipos de isolamentos, talvez por isso desconheciam a freqüência destas cepas, bem como a falta de informação diretamente relacionada à percepção da susceptibilidade da doença, devido à situação de risco apresentada.

Quanto ao modo de transmissão das BMR, os profissionais entrevistados mencionaram predominantemente o contato direto e indireto; em sua minoria, os demais modos de transmissão; quanto ao conhecimento sobre os principais reservatórios destes microrganismos, as respostas ficaram restritas quase que exclusivamente ao ambiente / superfícies e ao paciente, sendo pouco mencionados reservatórios tão importantes, como o próprio profissional de saúde e o material contaminado.

Uma das variáveis estruturais refere-se ao conhecimento sobre a doença, isto é, quanto maior for o conhecimento do profissional de saúde sobre a doença, maior será sua influência à ação final para adoção de medidas preventivas para o cuidado dos portadores de BMR. De acordo com análise realizada, percebemos que o conhecimento dos profissionais de saúde 
necessita ser ampliado para que tenham maior apreensão ao Protocolo de Medidas Preventivas que deve ser adotado no cuidado aos portadores de BMR.

Este tipo de estudo relacionado ao comportamento preventivo, de acordo com a definição de Rosenstock (1974b), insere-se na revisão que realizou do MCS, utilizando as citações a respeito dos diferentes comportamentos de saúde. Assim, entende como Comportamento na saúde ( health behavior) “[...] qualquer atividade apreendida por uma pessoa que acredita estar saudável, com o propósito de prevenir doenças ou de detectá-las em um estágio assintomático”. O comportamento de saúde está relacionado ao desejo de evitar doenças e continuar saudável.

Então, visando identificar o conhecimento dos profissionais de enfermagem do Hospital Geral de Passos - MG, sobre bactérias multirresistentes e a dimensão do Modelo de Crenças, encontramos as seguintes subcategorias: percepção da susceptibilidade da doença pelo funcionário; severidade da doença; influência da instituição; influência pessoal; relação entre benefícios e barreiras; identificação das causas que determinam ou dificultam a adesão, ou seja, a relação entre as barreiras e benefícios encontrada por enfermeiros e auxiliares de enfermagem quanto à adesão às medidas de precaução na assistência prestada a portadores de microrganismos multirresistentes. A partir daí, apreendemos entre os entrevistados as seguintes percepções: 


\subsection{Modelo de Crenças em Saúde como determinante do comportamento preventivo em saúde}

\subsubsection{Percepções Individuais}

\subsubsection{Percepção de susceptibilidade da doença}

“Susceptibilidade percebida - refere-se à percepção subjetiva do risco pessoal de contrair uma doença” (ROSENSTOCK, 1974b).

Os profissionais entrevistados, em sua quase totalidade, aperceberam-se como susceptíveis de contrair BMR e relacionaram o medo de contrair a doença a barreiras como: demora no diagnóstico para adoção das medidas preventivas; variáveis psicossociais, onde a maior preocupação referia-se ao medo de transmitir a doença aos familiares, comprometendo assim, sua vida pessoal; desvalorização profissional e a severidade da doença. Além de suas próprias percepções, eles ainda contavam com as impressões apreendidas dos pacientes portadores de BMR, nas quais predominavam os aspectos negativos, principalmente o medo, a depressão e a discriminação, todos estes somados ao seu próprio medo de adquirir a doença. Contudo, os profissionais referiram apropriar-se das medidas preventivas para prevenirem de contrair a doença, valendo-se principalmente dos EPI, mais do que da lavagem das mãos e das demais medidas, apesar de que em análise detalhada pudemos observar que elas não são seguidas por um grupo muito representativo.

\subsubsection{Percepção da severidade da doença}

Severidade percebida - a gravidade ou seriedade da doença pode ser avaliada pelo grau de perturbação emocional criado ao pensar na doença quanto pelos tipos de conseqüências que a doença pode acarretar: dor, morte, gasto material, interrupção de atividades, perturbações nas relações familiares e sociais, etc.,...(Rosenstock, 1974b) 
A maioria dos profissionais entrevistados associou a gravidade das doenças causadas por BMR a tratamento difícil ou à maior índice de mortalidade, alguns ainda a associaram a tratamento inexistente; somente um profissional a considerou como qualquer outra doença. Para os outros profissionais, esta doença pode levar à morte e interromper as atividades devido à longa permanência no hospital. Quanto às percepções apreendidas pelo paciente isolado, estas se referem ao medo, depressão, discriminação, entre outras, ou seja, para estes profissionais a severidade influencia suas percepções individuais.

\subsubsection{Fatores Modificadores}

\subsubsection{Estímulos para ação}

Rosenstock (1974b), em sua revisão dos estudos sobre o MCS e prevenção, fez uma análise crítica deste modelo, já que os primeiros estudos não fizeram nenhuma formulação do conceito motivacional. Segundo Antonovsky; Katz (1970), motivação é o comportamento orientado para uma meta, isto é, à manutenção da saúde. Para Rosenstock (1974b) os fatores cognitivos do modelo original desempenham um papel um tanto independente, como determinantes do comportamento, contudo a motivação é uma condição necessária para a ação, e os motivos agem seletivamente na determinação das percepções do ambiente pelo indivíduo.

Em artigo publicado em 1966, Kasl e Cobb operacionalizaram a motivação como um estado psicológico de prontidão para a ação específica e também à crença em que um particular curso da ação beneficiará a redução da ameaça causada pela doença. A variável motivacional não aparece explicitamente no modelo, senão em 1974, na proposta de Becker (1974b) referente ao estudo do comportamento na situação de doença, sendo modelo testado no estudo de Becker, Drachman e Kirscht (1974). Na proposta destes autores, a motivação "se 
refere a um estado emocional diferenciado causado no indivíduo por algum tipo de estímulo”, sendo medida através de quatro dimensões: ameaça física, controle das questões de saúde, atitude com relação à autoridade médica e interesse na saúde, de modelo geral. O referido artigo tem também o mérito de estender o modelo a comportamentos de saúde na situação de doença

Em 1975, Becker et al. publicaram estudo sobre a aplicação do MCS na detecção da doença de Tay-Sachs, e esta foi, segundo Rosenstock(1974b), a primeira vez que a motivação para a saúde foi introduzida no modelo para explicação de um comportamento preventivo.

A partir destas formulações do modelo, os estudos que se seguiram fizeram adaptações para diferentes tipos de comportamentos de saúde, de doenças específicas, de objetivos particulares, incluindo ou não a motivação como uma das dimensões dos modelos propostos (COLETA, 2004).

Consideramos neste estudo que a influência da instituição e a influência pessoal agiram como fatores modificadores, sendo a influência pessoal uma variável psicossocial (personalidade) e a influência da instituição, estímulo para a ação.

\subsection{Influência da instituição}

Observamos que a instituição influenciou favoravelmente a adesão, proporcionando aos profissionais condições necessárias para atenderem ao Protocolo de Isolamento Específico, contudo, com eventuais falhas, passíveis de correção.

Alguns fatores de influência que contribuíram para maior apreensão das medidas de controle de infecção hospitalar e isolamento e considerados pelos profissionais de enfermagem como mais importantes, foram: treinamento adequado, disponibilidade dos EPI e a colaboração dos supervisores para às orientações necessárias. 
Também notamos que os profissionais obtiveram conhecimentos sobre o tema portadores de bactérias multirresistentes (BMR), predominantemente, pela CCIH, sendo estes percebidos como estímulos para ação, conforme MCS. Percebemos, ainda, que estes estímulos partiram principalmente da instituição, cabendo uma parcela de contribuição aos cursos de capacitação. Contudo, ficou evidente a ausência de outros estímulos importantes, como campanhas em massa, informativos institucionais, e o hábito da leitura de artigos, jornais e de consulta à internet. Pressupomos que estas informações não sejam freqüentemente fornecidas por meio de comunicação popular como: rádio, televisão, jornal, pois nenhum dos profissionais entrevistados as citaram. Assim, consideramos que os estímulos para ação estão sendo subutilizados pela mídia, dificultando a compreensão e apreensão das medidas utilizadas para evitar a disseminação das BMR. Entretanto, quando se referiram às táticas de prevenção mais efetivamente utilizadas na instituição, pelo Serviço de Controle de Infecção Hospitalar (SCIH), os profissionais optaram pela presença in locu da enfermeira ou infectologista para abordar o assunto e também pelas atividades de atualização, ou seja, divulgação do conhecimento de maneira informal, diferentemente do planejamento utilizado mais freqüentemente nessa instituição, que é o treinamento do tipo formal.

Notamos que a placa sinalizadora colocada na porta do quarto do paciente, uma das medidas educativas adotadas pela instituição, foi bem aceita pela maioria dos profissionais, que a consideraram educativa, orientadora, necessária e importante.

O comportamento dos profissionais com relação ao uso dos EPI evidenciou controvérsias, pois muitos relataram utilizar mais freqüentemente os paramentos, enquanto outros informaram não utilizá-los rigorosamente, por diversos motivos, sendo os mais freqüentes a crença de que não vai contrair a doença, a divulgação tardia do diagnóstico, a resistência, ou seja, injustificadamente “...não usa porque não quer...” e o difícil acesso aos EPI, assim como sua inconveniência e interferência no trabalho. Para este componente, o 
estímulo à ação foram treinamentos realizados pela CIPA, durante a SIPAT, os quais foram considerados fatores que muito contribuíram para a adesão ao uso dos EPI, na instituição.

O MCS considera a presença de estímulos à ação fator importante para suscitar as percepções de susceptibilidade e severidade e motivar o indivíduo a agir. Os estímulos podem ser internos e externos; neste contexto os estímulos externos foram os treinamentos citados, que podem modificar as crenças individuais.

“O estímulo para a ação, considerado como necessário para ativar as variáveis da "prontidão para ação", parece servir para tornar os indivíduos conscientes dos seus sentimentos e aproximá-los do problema em questão” (MAIMAN; BECKER,1974).

\subsubsection{Variável psicossocial (personalidade)}

\subsection{Influência Pessoal}

Além do potencial para ação resultante dos níveis combinados de susceptibilidade e de severidade percebidas na doença, a modalidade de ação foi escolhida em função da percepção dos benefícios, excetuando-se as barreiras percebidas nas alternativas comportamentais. Então, fazem parte do MCS alguns estímulos que provocam o processo de tomada de decisão, os quais podem ter origem “interna” (por exemplo um sintoma) ou “externa” (influência da família, dos amigos, dos meios de comunicação etc).

Outras variáveis podem afetar a percepção individual, influenciando indiretamente a ação final, e estas referem-se aos fatores biográficos, psicossociais e estruturais.

Acredita-se que algumas variáveis demográficas, psicossociais e estruturais poderiam, em uma dada instância, afetar a percepção individual e indiretamente influenciar comportamentos relacionados á saúde. Alguns destes fatores, particularmente, o nível cultural do indivíduo exerceriam efeito indireto sobre o comportamento, influenciando as percepções de susceptibilidade, severidade, benefícios e barreiras (ROSENSTOCK et. al., 1990). 
Coleta (2004) conclui que, de modo geral, os estudos que se propuseram a testar o MCS, consideraram basicamente suas dimensões principais, as crenças e a motivação dando pouca atenção aos fatores modificadores das crenças e menos ainda aos "estímulos para ação”. Na literatura, raros são os estudos que apresentam algum resultado a respeito do papel destes últimos no modelo ou como eliciador de comportamentos de saúde.

Contudo, acreditamos que a elucidação da variável psicossocial, mais precisamente as atitudes individuais do profissional de enfermagem, categorizada como influência pessoal é importante para o planejamento das ações que visam à adesão do profissional às medidas preventivas ao cuidado do portador de BMR. O conhecimento das interações interpessoais do profissional de enfermagem, bem de sua conduta na assistência ao portador de BMR fornecerão os subsídios necessários para corrigir as falhas, identificar as crenças pessoais e as carências a respeito do conhecimento do assunto.

Ao analisarmos as atitudes relacionadas à influência pessoal do profissional de enfermagem, ou seja, a aplicação de seu conhecimento na prática diária, interações interpessoais, influência do comportamento das outras pessoas sobre o comportamento individual, crenças pessoais e comportamento pessoal, obtivemos informações importantes. Aproximadamente a metade dos profissionais de enfermagem entrevistados expressou lavar suas mãos antes e após o contato com o paciente portador de BMR e entre os procedimentos; outros lavam-nas antes e após o contato com o paciente e os demais entre os procedimentos e após o contato com o paciente. Entretanto, a maioria relatou lavar as mãos com mais freqüência quando o paciente era um portador de BMR.

Observamos que esses profissionais não faziam uso de pulseiras, a maioria utilizava relógio, apenas alguns usavam alianças e uma minoria apresentava as unhas grandes, porém portavam o uniforme limpo e boa aparência. 
Quanto ao uso dos EPI, eles consideraram o capote como o equipamento de maior dificuldade de utilização, por ser quente, seguido da máscara, em menor proporção, por sufocar ou embaçar o óculos.

Estes profissionais consideraram como medidas preventivas mais importantes na assistência ao portador de BMR a necessidade de quarto privativo, uso adequado de EPI e separação de material de uso único, ou seja, de todas as opções fornecidas somente a orientação aos visitantes não foi lembrada pela maioria, por se tratar de uma conduta exercida somente em alguns turnos de trabalho.

Somente uma pequena minoria apresentou algum tipo de alergia que a impossibilitava de utilizar algum tipo de EPI ou de executar alguma medida preventiva, sendo elas, eram alergias ao álcool e ao talco das luvas.

Em relação às suas interações interpessoais, alguns profissionais informaram receber influência do comportamento de outros profissionais, sendo os médicos mais freqüentemente citados como aqueles que não aderiram às medidas preventivas na assistência ao portador de BMR.

\subsubsection{Probabilidade de Ação}

\subsubsection{Relação entre benefícios e barreiras}

- $\quad$ Benefícios percebidos - referem-se à crença na efetividade da ação e à percepção de suas conseqüências positivas;

Barreiras percebidas - os aspectos negativos da ação são avaliados em uma análise do tipo custo-benefício, considerando possíveis custos de tempo, dinheiro, esforço, aborrecimentos, etc, .......(Rosenstock, 1974b)

A compreensão de que os benefícios das medidas preventivas na assistência ao portador de BMR se estendem ao profissional de enfermagem foi quase unânime, à exceção de um único profissional. Eles acreditavam que estes benefícios voltados para eles eram, 
principalmente, a proteção e a prevenção de adquirir a doença, quanto aos benefícios para o cliente, estes visavam evitar a aquisição de nova infecção, a disseminação, assim como sua proteção e segurança, ou seja, em ambos os casos a crença maior era que o isolamento específico protegia os profissionais e clientes.

Os fatores considerados como facilitadores para a adesão dos profissionais as medidas preventivas de Isolamento Específico foram orientação sobre a temática em questão; a rápida identificação do agente etiológico e aqueles relacionados como barreiras, principalmente a falta de vagas; o diagnóstico tardio e a falta de materiais. Ficaram evidentes que uma boa orientação aos profissionais associada ao diagnóstico precoce do patógeno, à vaga e ao material acessível foram os fatores primordiais para melhor adesão dos profissionais às medidas de controle dirigidas ao portador de BMR.

\subsubsection{Probabilidade de praticar a ação preventiva recomendada}

Os profissionais de enfermagem demonstraram percepções relacionadas à severidade das doenças causadas por microrganismo multirresistentes, suas implicações para o paciente, assim como o aumento da incidência de mortalidade e a dificuldade ou ausência de tratamento.

Quanto à percepção de susceptibilidade, os profissionais se referiram a alguns fatores, deixando de mencionar outros, levando-nos a supor que eles os desconheciam, porém aperceberam-se susceptíveis de contrair BMR. Demonstraram sensibilidade a diversos estímulos para ação, preferencialmente a estratégia de receber conhecimento através de métodos informais, ou seja, na prática diária em contato direto com o enfermeiro ou infectologista, bem como a constante atualização de conhecimento apreendido. 
Os entrevistados, em sua maioria, também informaram não ser influenciados pelo comportamento de outros profissionais ao decidirem aderir ou não às medidas preventivas no cuidado aos portadores de BMR.

Na avaliação, aprofundamos alguns fatores modificadores devido à sua relevância para o tema, sendo eles: a influência da instituição e a influência pessoal e constatamos que a influência da instituição apresentou-se significativa por ter se constituído no recurso mais importante para capacitar o profissional de conhecimentos essenciais sobre a problemática de BMR, e também por ter propiciado recursos para a adoção do Protocolo de Isolamento Específico, ou seja, a variável conhecimento da problemática sobre BMR versus adoção de medidas preventivas estão diretamente relacionadas, pois a conduta do profissional é mais coerente quando este possui conhecimento mais adequado.

Independentemente da influência da instituição, o profissional somente desenvolverá uma atitude correta se suas crenças pessoais estiverem de acordo com as orientações da instituição, e neste estudo pudemos observar que muitos profissionais não aderiram totalmente às medidas de controle na assistência aos portadores de BMR, ao não lavarem as mãos ou friccionarem com álcool na freqüência que deveriam. Também pudemos deduzir que não adotaram as precauções-padrão, pois referiram lavar as mãos com maior freqüência quando estavam assistindo um portador de BMR.

Alguns profissionais não utilizavam criteriosamente a paramentação, como foi citado pela maioria dos entrevistados, devido à crença de que não iriam contrair a doença ou simplesmente por resistência. Também acreditavam que não adiantava se paramentarem após a identificação do patógeno multirresistente se já haviam cuidado do paciente por longo tempo, sem paramentação. Ainda neste contexto, alegaram o difícil acesso aos EPI, sua inconveniência e interferência no trabalho, fatores também associados à interferência da instituição. 
Estes aspectos, ao nosso ver, devem ser exaustivamente trabalhados, pois sem a desmistificação destas crenças, com certeza, a adesão não se consolidará.

A percepção das barreiras relacionou-se prioritariamente à falta de leitos para isolamentos, ou seja, à dificuldade para isolar o paciente e à demora para a identificação do patógeno, fatores já mencionados anteriormente, que por serem relevantes devem ser trabalhados, juntamente com a falta de material disponível.

A percepção de benefícios demonstrou-se equivocada, pois mencionaram neste item a necessidade do conhecimento profissional sobre o assunto e também o diagnóstico precoce da doença, o que nos leva a crer que listaram os requisitos para maior adesão às medidas preventivas aos portadores de BMR.

Brevidelli e Cianciarullo (2001) e Brevidelli (1997) utilizaram o MCS para quantificar as crenças individuais que poderiam estar influenciando a freqüência da prática de reencapar agulhas e sua análise indicou que as percepções de barreiras físicas, cognitivas e psicológicas foram as crenças mais importantes para explicar o comportamento dos profissionais de enfermagem.

Neste estudo acreditamos ter identificado os fatores relevantes para explicar a adesão ou a não às medidas preventivas na assistência aos portadores de BMR no hospital, campo do nosso estudo, ou seja, ficamos conhecendo as percepções de barreiras físicas, cognitivas e psicológicas para a adesão às medidas preventivas empregadas no cuidado aos portadores de BMR, assim como as informações necessárias para a construção de estratégias de intervenção capazes de alterar positivamente a situação observada.

Apesar de não haver uma formulação matemática para as interações entre as variáveis do Modelo de Crenças em Saúde, Kirscht (1974) afirma que:

[...] dos estudos realizados até aquela época, não havia nenhum que demonstrasse que a combinação das variáveis resultasse em uma decisão, e questiona que tipo de relação existiria entre os elementos: aditiva, multiplicativa ou interativa”. 


\section{CONSIDERAÇÕES FINAIS}

Observamos na prática diária que a adesão dos profissionais às medidas preventivas na assistência aos portadores de BMR não foi realizada na sua totalidade pelos profissionais de saúde, participantes deste estudo, no cuidado ao paciente. Segundo as recomendações dos CDC (1997) e do Protocolo de Isolamento Específico da instituição em estudo, estas medidas devem ser cumpridas a fim de se evitar a aquisição de BMR ou disseminação destas cepas no âmbito hospitalar. Por este motivo, esta pesquisa buscou embasamento empírico para subsidiar as estratégias de intervenção dirigidas aos profissionais de saúde, com a finalidade de aumentar a adesão dos mesmos a essa prática.

Considerando o fato de a instituição propiciar treinamentos aos profissionais e mesmo assim estes não modificarem suas condutas, fomos em busca de um referencial teórico fundamentado na influência das crenças individuais sobre o comportamento para embasar o estudo em questão. Para tanto, utilizamos o MCS que identificou as barreiras físicas, cognitivas e psicológicas que justificavam a não-adesão de alguns profissionais às medidas preventivas direcionadas ao portador de BMR.

As percepções dos profissionais relacionadas à severidade das doenças causadas por BMR eram adequadas, mas quanto à susceptibilidade da doença, o conhecimento apresentouse bastante limitado. Os benefícios das medidas a serem adotadas eram conhecidos por eles, porém criavam barreiras que dificultavam a adesão a essa prática. Os estímulos para a ação adotados pelo hospital, através da realização de treinamento formal não foram os preferidos pelos profissionais, que optaram por uma abordagem informal na prática diária.

A elaboração de estratégias de intervenção capazes de aprimorar a conduta dos profissionais de enfermagem, ou seja, de aumentar a adesão destes profissionais às medidas preventivas aos portadores de BMR, requer os seguintes quesitos: treinamento em reunião 
informal, a ser executado pela enfermeira e/ou pela infectologista do SCIH no próprio local de trabalho, direcionado aos profissionais da unidade, a fim de discutirem o assunto e esclarecerem as dúvidas, bem como realizarem treinamentos de atualização. Este treinamento deverá abordar o conhecimento específico sobre BMR, suas formas de transmissão, mecanismos de resistência, higienização das mãos, medidas preventivas direcionadas ao portador de BMR, a susceptibilidade do profissional de enfermagem e de outros pacientes à infecção por BMR, assim como demonstrar a freqüência de ocorrência destes patógenos na instituição e na unidade de trabalho. Este modelo de treinamento foi idealizado para atender as solicitações dos profissionais de enfermagem entrevistados que optaram por este tipo de abordagem, bem como para atender às necessidades identificadas.

Em atenção à dissolução das barreiras encontradas, consideramos necessário aumentar o número de vagas para pacientes que requerem precauções de isolamento, avaliação da conduta de solicitação de culturas, ou seja, solicitar ao corpo clínico da instituição a realização, o mais precocemente possível, da coleta de culturas para rápida identificação do patógeno. Recentemente foi implantado um Protocolo de Coleta de Culturas na UTI do hospital em estudo, que preconiza a solicitação das culturas de rotina em pacientes com sinais de infecção no ato da sua admissão. Contudo, será necessário esclarecer aos profissionais os mecanismos de resistência aos antimicrobianos para que, de posse deste conhecimento, eles compreendam que a identificação do microrganismo multirresistente dificilmente ocorrerá na internação do paciente e assim se desmistifique a crença que impera de que não adianta mais adotar as medidas preventivas após terem assistido o paciente sem a paramentação; organizar melhor a unidade para que os EPI estejam sempre disponíveis e que não faltem para uso individual. Os benefícios devem ser freqüentemente reforçados, ou seja, deve ficar sempre claro que a adesão às medidas preventivas está diretamente relacionada à prevenção de doenças do profissional e dos outros pacientes da instituição. 
A identificação dos problemas é imprescindível para a elaboração das estratégias de ação, pois a realidade das instituições não é freqüentemente a mesma, devendo a abordagem dos problemas locais estar relacionada à eficiência do programa a ser executado na instituição, só assim o MCS propiciará o caminho adequado para elucidação da problemática. Apesar das diferenças entre os serviços distintos, freqüentemente estudos de uma instituição refletem as condições de outras, porém com algumas particularidades devido às suas especificidades. Sendo assim, este estudo também poderá ser aplicado a outras instituições e contribuir para conscientização dos profissionais de enfermagem a respeito dos problemas mais freqüentes relativos às medidas preventivas adotadas na assistência aos portadores de BMR, orientação direcionada segundo a percepção das crenças dos profissionais de enfermagem. 


\section{REFERÊNCIAS BIBLIOGRÁFICAS*}

ANTONOVSKY, A.; KAIZ, R. The model dental patient: an empirical study of preventive health behavior. Social Science and Medicine, v. 4, p. 376-380, 1970.

ARAÚJO B. A. C.; OLIVEIRA, A. L.; SANTOS FILHO, L. Isolamento de amostras multirresistentes de staphylococcus aureus em estetoscópios usados no ambiente hospitalar. Revista brasileira de análises clínicas, v.32, n. 4, p: 285-288, 2000.

ASSOCIAÇÃO PAULISTA DE ESTUDOS E CONTROLE DE INFECÇÃO HOSPITALAR (APECIH ). Precauções e Isolamento . 2 ed. São Paulo, 1999.

BARDIN, L. Análise de Conteúdo. Tradução de Luís Antero Reto e Augusto Pinheiro. Lisboa: Edições 70, 1997.

BECKER, M. H. The Health Belief Model and sick role behavior. Health Edication Monographs, v. 2, n. 4, p.409-419, 1974a.

BECKER, M.H; DRACHMAN, R.; KIRSCHT, J. A new approach to explaining sick-role behavior in low income populations. American journal of Public Health, v. 64, n. 3, p.205216, 1974b.

BECKER, M. H.; et al. Some influences on public participation in a genetic screening program. Journal of Community Health, v. 1, p. 3-14, 1975.

BOYCE, J. M. MRSA patients; proven methods to treat colonization and infection. Journal Hospital Infection, v. 48, p. S9-S14, 2001.

BRASIL. Ministério da Saúde. Portaria N. 2.616 de 12 de Maio de 1998. Dispõe sobre o Programa de Controle de Infecção Hospitalar, Anexo IV - Lavagem das mãos. Diário Oficial da União, Brasília, mai. 1998.

BRASIL. Ministério da Saúde. Manual de controle de infecção hospitalar. Brasília: Centro de documentação do Ministério da Saúde, 1985.

BREVIDELLI, M. N.; CIANCIARULLO, T. I. Aplicação do modelo de crenças em saúde na prevenção dos acidentes com agulha. Revista de Saúde Pública, São Paulo, v. 2, n. 35, p. 193-201, 2001. Disponível em: <www.fsp.usp.br/rsp>. Acesso em: 19 fev. 2004.

BREVIDELLI, M. M. Exposição ocupacional ao vírus da AIDS e da hepatite B: análise da influência das crenças em saúde sobre a prática de reencapar agulhas. 1997. 152p. Dissertação (Mestrado) - Escola de Enfermagem de São Paulo, Universidade de São Paulo, São Paulo, 1997.

* UNIVERSIDADE DE SÃO PAULO. Sistema Integrado de Bibliotecas. Grupo D: Teses. Diretrizes para elaboração de Teses e Dissertações da USP: documento eletrônico ou impresso. São Paulo: SIBi/USP, 2003. 
CENTER FOR DISEASE CONTROL and PREVENCTION (CDC). Recommendations for Preventing the Spread of vancomicyn of resistence. Recommendations of the Hospital Infection Control Practices Advisory Committee (HICPAC). MMWR, Atlanta, n. 44, n. RR12, p. 1-13, 1995. Disponível em: <http://www.cdc.gov/mmwr>. Acesso em: 13 dez. 2002.

. Part I. Evolution of Isolation Practices. Issues in Healthcare Settings. 1997. Disponível em: <http://www.cdc.gov>. Acesso em: 13 dez. 2002.

. Part II. Recommendations for Isolation Precautions in Hospitals. Issues in Healthcare Settings. 1997. Disponível em: <http://www.cdc.gov>. Acesso em: 13 dez. 2002.

Resistence antimicrobial. MRSA - staphylococcus resistente methicillin aureus. 2002a. Issues in Healthcare Settings. Disponível em: <http://www.cdc.gov>. Acesso em: 13 dez, 2002.

. Resistence antimicrobial. MRSA - staphylococcus resistente methicillin aureus. 1999. Issues in Healthcare Settings. Disponível em: <http://www.cdc.gov>. Acesso em: 13 dez, 2002.

Prevention Guidelines System. Interim Guidelindes for prevention and control of staphylococcal infection associated with reduced susceptibility to vancomycin. MMWR. v 46, n. 27, p. 626-628, 635, 1998. Disponível em: <http://www.cdc.gov/mmwr>.

Division of Healthcare Quality Promotion (DHQP). Resistence antimicrobial VISA/ VRSA - staphylococcus vancomycin intermediate / resistent aureus. Issues in Healthcare Settings, 2002c. Disponível em: <http://www.cdc.gov>. Acesso em: 13 dez, 2002.

Guideline for Han Higiene in Health-Care Settings. MMWR. v.51, n. RR-16, 25

Oct., 2002b. Disponível em: <http://www.cdc.gov>. Acesso em: 13 dez, 2002.

CHOW, J.; W, et al. Enterobacter bacteremia: clinical features and emergence of antibiotic resistance during therapy. Am. Intern. Med., v. 115, p. 585-590, 1991.

COLETA, M. F. (Org.). Modelos para pesquisa e Modificação de Comportamentos de Saúde: teorias, estudos, instrumentos. Cabral, 2004, Editora e Livraria Universitária.

COLETA, M.F.O Modelo de crenças em saúde: uma aplicação a prevenção e controle da doença cardiovascular.1995. p. 152p. Tese (Doutorado em Psicologia) - Instituto de Psicologia, Universidade de Brasília, DF, 1995.

COUTINHO, A. C. CDC atualiza guidelines para lavagem das mãos. Controle de Infecção, São Paulo, Ano XII, n. 54, p. 1.

Estatuto da Irmandade do Hospital Geral de Passos - MG, 1986. 
FERNANDES, A.T. Infecção Hospitalar e suas Interfaces na Área da Saúde. São Paulo: Atheneu, 2000.

GIR, E. A sexualidade e a mulher portadora do vírus da imunodeficiência humana tipo 1 (HIV-1). 1997. Tese (Livre Docência em Enfermagem Geral e Especializada) - Escola de Enfermagem de Ribeirão Preto, Universidade de São Paulo, Ribeirão Preto, 1997.

GÓNGORA, R. F. Fatores de risco de colonização por bacilos gram-negativos multirresistentes na orofaringe de pacientes internados em unidade de terapia intensiva clínica-cirúrgica. 1999. 90 p. Tese (Doutorado em Medicina) - Escola Paulista de Medicina, Universidade Federal de São Paulo, São Paulo, 1999.

HSUEH, P. R. et al. Pandrug-resstant Acinetobacter baumannii causing nosocomial infections in a university hospital, Taiwan. Emerg Infect Dis, Taiwan, 2002. Disponível em: <http://www.cdc.gov/ncidod/EID/vol8no8/02-0014.htm>. acesso em: 18, fev., 2003.

JANZ, N. K.; BECKER, M. H. The health belief model: a decade later. Health Education Quaterly, v.11, n.1, p.1-47, 1984.

JARWIS, W.R. Resistência antibiótica no ambiente hospitalar: impacto, tendências e intervenções bem sucedidas para sua prevenção e controle de surtos.2000. In: CONGRESSO INTERNACIONAL DE CONTROLE DE INFECÇÕES HOSPITALARES. Resumo. Belo Horizonte, 2000. Disponível em: < $\underline{\text { www.ccih.med.br/resistantantibiotica-1.html>. }}$

JEUKENS, M. M. F. Equipe de enfermagem: aceitação e uso das precauções universais. São Paulo, 1997. 123p. Tese (Doutorado em Enfermagem) - Escola de Enfermagem da Universidade de São Paulo. São Paulo,1997.

KASL, S.; COBB, S. Health behavior, illness behavior and sick role behavior. Health Education Monographs, v.4, n.2, p. 387-408, 1966.

KIRSCHT, JP. P. The Health Belief Model and illness behavior. Health Education Monographs, v. 2, n. 4, p. 387-408, 1974.

LAUDMAN, D. Pseudomonas e Acinetobacter Multirresistentes assolam hospitais de Nova York. Arch Intern Med, v.162, p. 1515-1520, 2000. Disponível em:

<http://www.ccih.med.br/boletim-noticias2.html>. Acesso em: 18 fev. 2003.

MACHADO, A.R.L. Microrganismos multirresistentes em Unidades de Terapia Intensiva. Prática Hospitalar, ano V, n. 28, p. 25-58, jul./ ago. 2003.

MAIMAN. L. A; BECKER, M. H. (1974). The Health Belief Model: origins and correlates in psychological theory. Health Education Monographs, v. 2, n. 4, p. 336-353, 1974.

McCOY, K. D. et al: Monitoring adherence to Standard Precautions. American Journal Infection Control, v. 29, p. 24-31, 2001.

MINAYO, M.C.S. O desafio do conhecimento: pesquisa qualitativa em saúde. 6. ed. Hucitec, 1992. 
MINAYO, M. C. S.(Org.). Pesquisa Social: teoria, método e criatividade. Petrópolis: Vozes, 1994. 80p.

MORIYA, T. M. et al. Doenças transmissíveis e isolamento: a percepção de aluno de enfermagem. Revista da Escola de Enfermagem USP, v.29, n.3, p. 286-96, dez. 1995.

NAKAO, J. Aspectos da assistência a pacientes internados em unidade de isolamento em um Hospital Escola - Medidas preventivas utilizadas e custo do paciente dia. 1988.

Dissertação (Mestrado em Enfermagem) - Escola de enfermagem de Ribeirão Preto, Universidade de São Paulo, Ribeirão Preto, 1988.

NEVES NETO, A. R.; Ciências do comportamento e infecção hospitalar. APECIH Jornal, São Paulo, Ano 16, n.3, 2000. Ciência e prática, p.2.

ORGANIZAÇÃO MUNDIAL DE SAÚDE (OMS). World Health Report on Infections Disease 2000 - Vencendo a resistência microbiana. 2000. Disponível em:

<http://www.ccih.med.br/vencendoresistencia.html>. Acesso em: 31 jan. 2003.

PITTET D.; MOUROUGA P.; PERNEGER T.V. Compliance with handwashing in a teaching hospital. Infection Control Program. Ann Intern Med, v.130, p. 126-130, 1999.

RABAHI, M.F. et al. Tuberculose multirresistente: avaliação de 15 casos tratados no hospital de doenças tropicais ANUAR AUAD. In: Congresso Brasileiro de Infectologia, n. 054, 2003, Goiânia. Anais... Goiânia.

RABAHI, M.F; ALMEIDA NETTO, J.C. Tuberculose: risco ocupacional em profissionais de saúde. Rev. patol. Trop, v. 30, n. 1, p: 1-8, jan./ jun, 2001.

Regimento do Corpo Clínico da Santa Casa de Misericórdia de Passos. Passos, [198-].

RODRIGUES, E. A.C. et al. Infecções Hospitalares: prevenção e Controle, São Paulo: SARVIER, 1997. p. 561-569.

ROSENSTOCK, I. M. Historical origins of the health belief model. Health Education monographs, v.2, n.4, p. 328-335, 1974a.

ROSENSTOCK, I. M. et al. The health belief model: explaining health behavior through expectancies. In: Health behavior and health education: theory, research and practice. San Francisco: Jossey-Bass Publishers, 1990. Cap.3, p. 39-62.

ROSENSTOCK, I. M. The health belief model and preventive health behavior. Health Education Monographs, v.2, n.4, p.354-386, 1974 b.

SANTA CASA DE MISERICÓRDIA DE PASSOS. Sistema Integrado de Gestão Hospitalar: Estatística do SAME por centro de custo, Acessado: 2004. Passos, 2004.

SEISCENTO, M. et al. Tuberculose multirresistente (TBMR): aspectos clínicos-laboratoriais, epidemiológicos e terapêuticos. Journal pneumology, v. 23, n. 5, p. 237-244, set./ out. 1997. 
SERVIÇO DE CONTROLE DE INFECÇÃO HOSPITALAR (SCIH). Serviço automatizado de controle de infecção hospitalar (SACIH). Passos, 2003.

SIEVERT, D. M. et al. S. aureus resistant to vancomycin. MMWR, United States, 2002. Editorial.

SOUZA FILHO S.A. As taxas de infecção hospitalar como um indicador de qualidade nos hospitais: O desafio de diminuir a resistência. Meio de Cultura, São Paulo, Ano VI, n. 24, p. 3-7, 2003.

STARLING, C. E. F.; SILVA, E. U. (Coord.). Controle de Infecções Hospitalares: isolamento, precauções e controle de bactérias multirresistentes. Belo Horizonte: IEA, 1998a. Cap. 9, p. $11-24$.

STARLING, C. E. F.; SILVA, E. U. (Coord.). Controle de Infecções Hospitalares: microbiologia aplicada ao controle de infecções hospitalares. Belo Horizonte: IEA, 1998b. Cap. 10, p. 14.

TAKEDA, E.; ROBAZZI, M. L. C. C.; LAVRADOR, M. A. S. Risco ocupacional de adquirir tuberculose entre trabalhadores de enfermagem hospitalar. Rev. bras. Enf., v. 54, n. 3, p: 456-465, jul./ set, 2001.

TRESOLDI, A.T. et al. Fatores de risco relacionados à aquisição de bactérias multirresistentes em unidade de internação pediátrica. J. Pediatr., Rio de Janeiro, v. 76, n. 4, p. 275-280, jul./ ago. 2000.

VELASCO, E; MARTINS, C. A. S. Infecções em pacientes imunossuprimidos sem AIDS. J. bras. Méd., v. 66, n. 3, p. 48-50, mar. 1994.

VIEIRA, L.A. et al. Colonização intestinal de recém-natos por enterobactérias multirresistentes a antimicrobianos em unidade neonatal. J. pediatr., Rio de Janeiro, v. 75, n.2, p. 83-90, mar./ abr. 1999.

ZAIDI, M.; MARTÍN, G; ROSADO, R. Epidemia de neumonía asociada a ventilación mecánica en Mérida, Yucatán. Salud públ. Méx, v. 41, n. 1, p: S38-543, 1999. Suplemento 1. 


\title{
11 APÊNDICES
}

\author{
A - Formulário para Entrevista
}

MONITORANDO A ADERÊNCIA ÀS MEDIDAS PREVENTIVAS EMPREGADAS

PARA ISOLAMENTO EM PORTADORES DE BACTÉRIAS

\section{MULTIRRESISTENTES (BMR)}

\section{Dados de Identificação}

Categoria Profissional

$\square$ enfermeiro

$\square$ técnico de enfermagem

$\square$ auxiliar de enfermagem

Tempo de serviço anos

Turno de trabalho

matutino

vespertino

$\square$ noturno

\section{Sexo}

$\square$ feminino

$\square$ masculino

Idade

anos

Unidade de trabalho
Ala GI ( Clínica Médica Masc. )
Ala GII ( Clínica Médica Fem. )
Ala G ( Clínica Cirúrgica
UTI 


\section{$\underline{\text { II Conhecimento sobre bactérias multirresistentes (BMR) }}$}

1. Você sabe me dizer porque algumas bactérias ficam multirresistentes?

2.Um paciente com BMR oferece algum risco para a equipe de saúde?

$\square$ Sim. Que tipo de risco?

$\square$ Não

3.Onde encontram-se localizadas as BMR no organismo do paciente?

4.Quais são os microrganismos comumente encontrados nos pacientes deste hospital ?

5.Existe paciente mais susceptível a colonização por BMR a nível hospitalar? Se sim, cite quais.

6.De quem vocês costumam receber orientações sobre as precauções necessárias que devem ser empregadas aos portadores de BMR?

Médico do paciente

Médica da CCIH

Enfermeiro do setor

Supervisor

Enfermeira da CCIH

Outros

7.Com qual freqüência ocorre a presença de cepas multirresistentes no hospital ? E no seu setor?

8.Como as BMR são transmitidas de um indivíduo a outro?

9.Quais são os principais reservatórios destes microrganismos? 
III Dimensão do Modelo de Crenças

\section{Percepcão de susceptibilidade da doença pelo funcionário}

\subsection{Você tem medo de contrair BMR ?}

1.2 Como podemos nos prevenir de contrair BMR? Cite algumas medidas essenciais.

1.3 Qual é a atitude do paciente ao ser informado sobre a doença e a necessidade de isolamento? Descreva .

\section{Severidade da doença}

2.1 Quanto a gravidade das doenças, como você considera as que são causadas por BMR ? Assinalar todas as alternativas que considerar corretas.

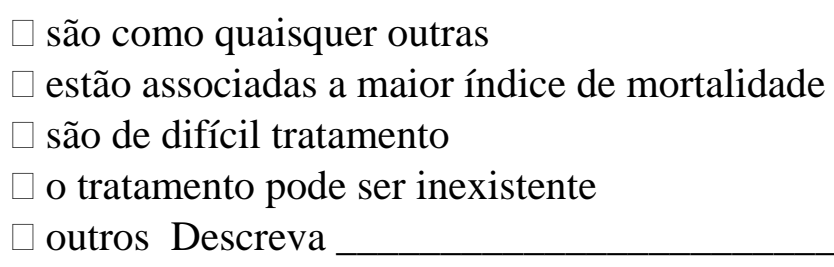

2.2 Cite as medidas preventivas para diminuir a disseminação desse agente, que devem ser empregadas nestas situações? 


\section{Influência da instituição}

3.1 A instituição propicia as condições necessárias para viabilizar a execução do Protocolo de Isolamento Específico?

\section{Sim}

Sim, parcialmente. Porque?

$\square$ Não, Porque?

Se sim, liste os fatores relacionados que você considera mais importantes.

$\square$ Treinamento adequado

supervisores colaboram na orientação e reforço das práticas adequadas

$\square$ informação em todos os setores sobre os riscos dos patógenos transmitidos pelo sangue

EPI disponíveis nos locais necessários

$\square$ treinamento especial para uso de EPI

outras

3.2 Como adquiriu conhecimento sobre a problemática do portador de bactérias multirresistentes? Onde? Por quem?

3.3 Qual a sua opinião sobre a colocação da placa, com figura ilustrativa dos EPI fixada na porta do quarto de isolamento?

3.4.Quais são as razões para desobediência do uso dos Equipamentos de Proteção Individual (EPI) ?

Interfere no trabalho

Acesso difícil dos EPI

Inconveniência do seu uso

Inabilidade para seu emprego

Desconhecimento da indicação para uso

Outros

3.5.A Semana Interna de Prevenção de Acidentes ( SIPAT ) promovida pela CIPA contribui para adesão aos EPI ?
sim, muito
sim, pouco
não
não sei 
3.6. Quais as táticas de prevenção utilizadas pelo SCIH, você considera mais efetiva para conseguir maior adesão dos profissionais de saúde às medidas preventivas dirigidas aos portadores de bactérias multirresistentes? Liste as 02 que você julga mais importantes .

informativos conscientizando sobre o benefício para o paciente ao atender o Protocolo de Isolamento Específico;

$\square$ a enfermeira e/ou infectologista reunir com os funcionários as explicar medidas preventivas, informalmente

contar com a supervisão rigorosa e colaboração do enfermeiro do setor

elaborar manual de procedimento

programar atividades de atualização solicitadas pela equipe de enfermagem, formalmente.

\section{Influência pessoal}

4.1 Considerando o fato de estar cuidando de um paciente portador de bactérias multirresistentes, (BMR ) descreva, quando lava suas mãos? Qual produto utiliza?

4.2 Você utiliza o álcool glicerinado a 70\% nas mãos em quais situações?

4.3 Qual o EPI representa maior dificuldade de utilização?

máscara

$\square$ luvas

$\square$ capote

Porque?

4.4 Indique quais condutas você adota ao assistir um paciente portador de bactéria resistente.

uso adequado de EPI

separação do material de uso único

solicitação de quarto privativo para o paciente

orientação aos visitantes

Se algum item não foi selecionado justifique o motivo

4.5.O fato do paciente estar em isolamento faz com que você lave as mãos com a mesma freqüência do paciente não isolado?

maior freqüência

igual freqüência

menor freqüência

Porque? 
4.6 Quanto a seu comportamento pessoal, quais são as atitudes pertinentes à sua conduta no trabalho?

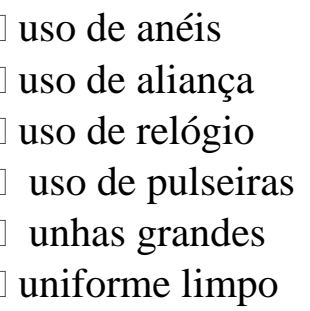

4.7 $\mathrm{O}$ fato de outros profissionais eventualmente ou freqüentemente não utilizar a paramentação recomendada, influencia no seu comportamento ou de seus colegas?

$$
\begin{aligned}
& \square \text { sim } \\
& \square \text { não }
\end{aligned}
$$

Se sim, na sua opinião quais os profissionais que menos aderem às orientações do Protocolo de Isolamento Específico ?

4.8 Possui algum tipo de alergia que impossibilita a adoção a alguma destas medidas preventivas específicas para evitar a disseminação das BMR?
$\operatorname{sim}$
não

Se sim, qual?

\section{Relação entre benefícios e barreiras}

5.1 A adequação as medidas preventivas específicas promovem benefícios para você?

$\square \operatorname{sim}$

$\square$ não

Se sim, quais

benefícios?

5.2 A adequação as medidas preventivas específicas promovem benefícios para o cliente?

$\operatorname{sim}$

não

Se sim, quais benefícios?

5.3 Quais são os principais fatores que facilitam o emprego das medidas preventivas?

5.4 Quais são os principiais fatores que dificultam / impedem o emprego das medidas preventivas? 


\section{ANEXO}

\section{A - PARECER DO COMITÊ DE ÉTICA EM PESQUISA}
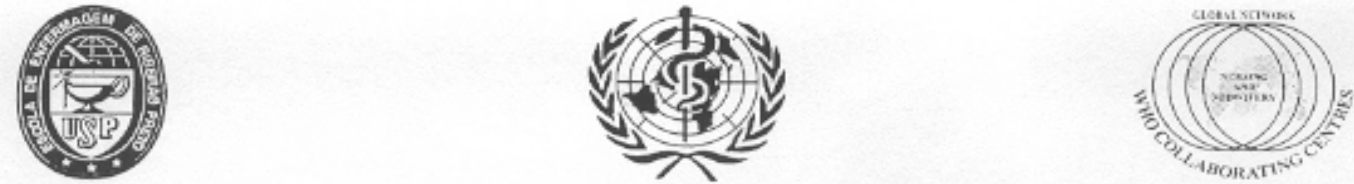

ESCOLA DE ENFERMAGEM DE RIBEIRÃO PRETO - UNIVERSIDADE DE SÃO PAULO CENTRO COLABORADOR DA ORGANIZAÇÃO MUNDIAL DA SAÚDE PARA O DESENVOLVIMENTO DA PESQUISA EM ENFERMAGEM

Avenida Bandeirantes, 3900 - Campus Universitário - Ribeirảo Preto - CEP 14040-902 - São Paulo - Brasil FAX: $55-016-633-3271 / 55-016-630-2561 /$ TELEFONES: $55-016-633-0379 / 602-3382$

\section{COMITÊ DE ÉTICA EM PESQUISA DA EERP/USP}

Of.CEP-EERP/USP - 066/2003

Ribeirão Preto, 22 de maio de 2003

Prezada Senhora,

Comunicamos que o projeto de pesquisa, abaixo especificado, foi analisado e considerado APROVADO pelo Comitê de Ética em Pesquisa da Escola de Enfermagem de Ribeirão Preto da Universidade de São Paulo, em sua $50^{\text {a }}$ Reuniăo Ordinária, realizada em 21 de maio de 2003.

Protocolo: $\quad n^{\circ} 0363 / 2003$

Projeto: ADESÃO ÀS PRECAUÇŌES EMPREGADAS NA ASSISTENCIA A PORTADORES DE MICRORGANISMOS MULTI-RESISTENTES

Pesquisadores: · ELUCIR GIR/ JOSELEY PINTO DE MOURA

Em atendimento à Resolução 196/96, deverá ser encaminhado ao CEP o relatório final da pesquisa e a publicaçăo de seus resultados, para acompanhamento, bem como comunicada qualquer intercorrência ou a sua interrupção.

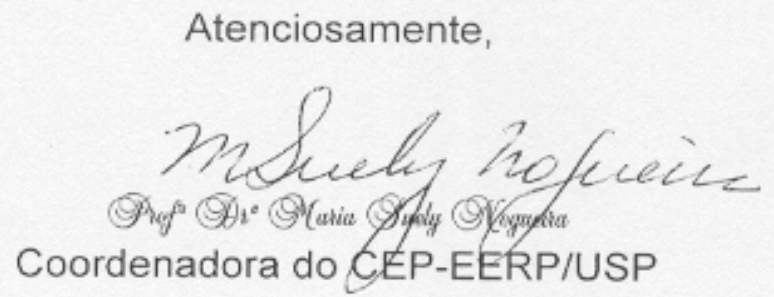

Ilma. Sra.

Prof $^{\mathrm{a}}$ Dra $^{\mathrm{a}}$ Elucir Gir

Departamento de Enfermagem Geral e Especializada

Escola de Enfermagem de Ribeirão Preto - USP 